3. HISTORIA DEL DERECHO EUROPEO 

Revista de Estudios Histórico-Jurídicos

[Sección Historia del Derecho Europeo]

XXXII (Valparaíso, Chile, 2010)

[pp. 221 - 280]

\title{
El pROCESO CONTRA TOMÁs MORO
}

[The Trial Against Thomas More]

\author{
Hernán Corral Talciani* \\ Universidad de los Andes, Santiago de Chile
}

\section{RESUMEN}

El trabajo pretende examinar el proceso por alta traición y otros delitos que se siguió en contra del ex canciller de Inglaterra, Tomás Moro, desde una perspectiva estrictamente jurídica; para lo cual se vale de los relatos contemporáneos de lo acaecido, las primeras biografías de Moro, la literatura moderna sobre ese proceso y sobre el personaje.

Palabras clave: Tomás Moro - Proceso penal contra T. Moro.

\section{Abstract}

This work intends to examine, from a strictly legal point of view, the prosecution for high treason and other crimes against the former Chancellor of England, Thomas More, based on contemporaneous statements of the facts, More's first biographies, modern literature on that trial and that character.

KEYWORDS: Thomas More - Criminal proceedings against T. More.

* Profesor de la Facultad de Derecho de la Universidad de los Andes. Dirección postal: Universidad de los Andes, Facultad de Derecho, San Carlos de Apoquindo 1600, Las Condes, Santiago, Chile. Correo electrónico: hcorral@uandes.cl 


\section{UN PROCESO CÉLEBRE: RAZONES Y FUENTES DEL ESTUDIO}

Sin duda dentro de los juicios célebres que nos proporciona la historia, junto a los de Sócrates, Jesús de Nazareth, Juana de Arco, Galileo, Alfred Dreyfus, Zacco y Vanseti y otros similares, el juicio de Tomás Moro, humanista, abogado, juez y lord canciller de Inglaterra, tiene un lugar destacado.

El juicio es de los más conocidos, ya que la obra de teatro de Robert Bolt, $A$ Man for All Seasons (1960) ${ }^{1}$, luego llevada al cine con el mismo título por Fred Zinneman con premiación de seis óscares ${ }^{2}$; y más recientemente la serie The Tudors ${ }^{3}$, han escenificado con electrizante dramatismo la lucha entre el ilustre prisionero y los ministros de Enrique VIII empeñados en doblegar la voluntad del rebelde o hacerlo morir con la infamia de los traidores. Tiene la particularidad de que el acusado, que actúa como su propio defensor, es un habilidoso y experimentado abogado y había sido juez en el mismo Palacio en el que fue juzgado.

No obstante, el proceso ha sufrido la misma suerte que la figura del "hombre para todas las horas" como lo llamó su buen amigo Erasmo. Para los católicos, sobre todo los sufridos católicos ingleses, se trató nada más que de un simulacro en que la sala del Tribunal no fue más que la arena donde el mártir defendió su fe y su adhesión a la Iglesia y al papa y ofrendó su vida como inmolación. Para los no católicos e incluso no creyentes, que también admiran a Moro como un hombre íntegro y que se adelantó a sus tiempos defendiendo la libertad de expresión y de conciencia, el juicio fue la representación de la lucha entre el depotismo absolutista y el individuo que intenta velar por la intangibilidad de su propia conciencia personal, sin relación con que su dictamen sea verdadero o falso.

En estas dos versiones se descuida algo que parece fundamental si se quieren mirar los acontecimientos y las personas con una mayor objetividad histórica: se trató de un juicio real, que se ciñó al menos en las formalidades a la legislación vigente en la época, y en el que el acusado era el abogado más culto y talentoso del reino, admirado además por su integridad y honorabilidad moral. Tomás Moro nunca presumió de mártir ni buscó su propia muerte, menos acusado de un crimen que repugnaba completamente a su personalidad y su trayectoria como consejero

${ }^{1}$ La obra fue escrita en 1954, y primero fue transmitida por la BBC radio. Pero saltó a la fama cuando en 1960 fue producida por el London's Globe Theatre. Cfr. BolT, Robert, $A$ Man for All Seasons. A Play of Sir Thomas More (London, 1995).

${ }^{2}$ La película fue estrenada en diciembre de 1966, con las actuaciones de Paul Scofield, Robert Shaw, Orson Welles, Susannah York y John Hurt. Entre los óscares que ganó están el de a la mejor película, al mejor director y al mejor actor (Paul Scofield). En 1988 se estrenó un "remake" para televisión, dirigido y protagonizado por Charles Helton.

${ }^{3}$ La serie, que lleva ya tres temporadas, fue creada por Michael Hirst y es producida por Peace Arch Entertainment para el canal de cable Showtime, en asociación con Reveille Productions, Working Title Films y la Canadian Broadcasting Corporation. Se estrenó en abril de 2007, y ha seguido proyectándose por temporadas el 2008 y el 2009. Tomás Moro es interpretado por el actor inglés Jeremy Northam. La prisión y juicio de Moro están detalladamente representados en el capítulo $5^{\circ}$ de la Segunda Temporada, titulado "His Majesty's Pleasure". La serie está disponible en DVD: "The Tudors. The Complete Second Season”, TM Productions Limited/PA Tudors II Inc. Una coproducción Irlanda-Canadá, 2008. 
y funcionario real. Se defendió magistralmente y, aunque finalmente perdió, lo hizo de una manera tal que nadie pudo tachar su muerte de indigna o miserable. Por el contrario, su figura creció a los ojos de todos y se encaramó en la posteridad superando incluso los conflictos políticos y religiosos de su época.

Conviene, en consecuencia, hacerse cargo del estudio del proceso y condena de Tomás Moro tratando de analizar y escudriñar todos sus ribetes jurídicos. Ello permite iluminar mejor la conducta tanto de Moro como de sus adversarios, así como lo que realmente estaba en juego en la contienda litigiosa. Esta indagación asimismo puede dar luz sobre algunos puntos que pueden ser tenidos como precursores de futuras tendencias que serán más tarde consagradas en el derecho penal de los tiempos modernos. Así, más de alguno se sorprenderá de cómo Moro utiliza lo que hoy día llamaríamos un recurso de inconstitucionalidad de la ley, invocando la Carta Magna, o cómo alega en su favor la prohibición de doble incriminación ("non bis in idem"). La irretroactividad de la ley penal, la necesidad de un dolo específico para el delito de traición, el problema del silencio como forma de actuación, la obligación o no de tener por buenas las decisiones consentidas por la mayoría de un Parlamento, la plena prueba por uno o dos testigos, son algunas de las cuestiones que saldrán a relucir en este histórico proceso y que justifican que se le estudie y se le tenga presente como un antecedente importante de nuestras actuales convicciones jurídicas.

La reconstrucción que nos proponemos hacer está fundada en cuatro tipos de fuentes. Las primeras son los primeros relatos del juicio y ejecución de Moro que se conservan, y que, al parecer, emanan de testigos presenciales que lograron llegar a Europa pocos días después del 6 de julio de 1535, fecha de la muerte de Moro, y difundieron la noticia. Recuérdese que el humanista tenía gran renombre en el Continente y que su Utopía era ya una obra famosa. La más antigua e influyente de estas relaciones se redactó en francés en París, y es conocida por los historiadores como The Paris News Letter ${ }^{4}$. Otros relatos se basan en ella ${ }^{5}$, incluidas una en la que se ha creído ver al menos parcialmente la pluma de Erasmo

${ }^{4} \mathrm{El}$ documento original se ha perdido, pero se conservan ocho copias manuscritas en la Biblioteca Nacional de París: el texto con el título Discours sur le procez et execution de Thomas Morus, chancellier d'Angleterre fue publicado por R. W. Chambers como apéndice a la primera edición de la biografía de Moro de Harpsfield: HarpsField, Nicholas, The Life and Death of St. Thomas Moore, Knight, sometymes Lord High Chancellor of England (London, 1932, reimp. 1963), Apéndice II: The Paris News Letter, pp. 258-266. Una versión en inglés es reproducida en Wegemer, Gerard B. - Smith, Stephen W. (editores), A Thomas More Source Book (Washington, 2004), pp. 352-355. En este trabajo, la citamos como The Paris News Letter, seguida de la página de la versión recogida como apéndice en la biografía de Harpsfield.

${ }^{5}$ Una relación compuesta en latín, al parecer entre 1535 y 1556, fue descubierta en 1934 , y es llamada Ordo (= Ordo condemnationis Thomae Mori, Cancellarii Primarii Aliquando Regni Angliae, quia in incestas nuptias Henrici Octavi assentiri, eumque caput summum Ecclesie Anglicanae fateri noluerit: compendio latine redditus: anno illoquo ille perierat). Otro relato se encuentra en un documento llamado Novitates, y que parece un panfleto contra Enrique VIII fechado el 24 de abril de 1536, impreso en Alemania sin indicación de autoría. Una versión en italiano del proceso contra Moro ("Relación italiana") aparece en una carta del cardenal Niccoló Schomerg al cardenal Marino Caracciolo, fechada el 12 de agosto de 1535, que se conserva en los archivos vaticanos y que por primera vez fue publicada en RuSCELLI, G., Lettere 
$\left(\right.$ Expositio $^{6}$ y otra que se ha conservado en español en el archivo de Simancas ${ }^{7}$. A estas primeras relaciones debe añadirse el relato del cardenal Reginal Pole en su obra en defensa de la unidad de la Iglesia ${ }^{8}$, aunque algunos piensan que se resiente de un carácter hagiográfico y del deseo de pintar a Enrique VIII como un déspota y tirano. Dentro de estos primeros documentos, especial relevancia tienen el texto de la acusación formulada contra Moro, el llamado "indictmen", escrito en latín, y que se ha conservado íntegramente9. Un breve relato encontrado en los informes privados de sir John Spelman, uno de los integrantes de la Comisión que juzgó a Moro, puede ser considerado, aunque es poco lo que añade a los demás documentos contemporáneos ${ }^{10}$. Las cartas de Moro que anteceden al juicio sirven para iluminar la forma en que se llegó a él y la actitud de este después de su renuncia a la Cancillería ${ }^{11}$.

di principe, le quali o si scrivono da principi, o a principi, o ragionan di principi (Venezia, 1562), I, pp. 127-129 (disponible en www.santommasomoro.com/moro_ita/moro_italia.htm).

${ }^{6}$ Una versión en latín del relato de la Paris News Letter, impresa en el otoño de 1535 en Basle por Jerome Froben, es denominada Expositio (= Expositio fidelis de morte D. Thomae Mori et quorundam aliorum insignium virorum in Anglia). En ella se dice que la nota de París fue escrita el 21 de julio de 1535 como carta de P. M. a Gaspar Agripino. Se ha creído que Erasmo tomó parte en su redacción: el recopilador del Epistolario de Erasmo, P.S. Allen, parece haber creído en esta autoría ya que la incluyó como Apéndice: cfr. la traducción al castellano que se publica en Erasmo, Desiderio, Obras escogidas (trad. castellana, Madrid, 1956), pp. 1395-1403. Pero no hay antecedentes definitivos que avalen la autoría de Erasmo y otros piensan que a lo más el humanista se contentó con proponer la compilación del documento y sugerir su forma y las ideas del comentario final: Chambers, R. W., en el comentario inicial a la edición de The Paris News Letter como "Apéndice" a la biografía de Harpsfield (p. 255), sostiene que la impresión de la Expositio se hizo bajo la dirección indudable de Erasmo que se había mudado a Basle en junio de 1535 y estaba alojando con Froben, el impresor.

${ }^{7}$ Existen dos copias que se conservan en el Archivo de Simancas y en el de la Real Academia de la Historia: un texto que las refunde es publicado como apéndice II en la biografía de Vasquez de Prada, Andrés, Sir Tomás Moro, Lord canciller de Inglaterra (6a edición, Madrid, 1999), pp. 394-400. La citamos como "Relación castellana", seguida de la página de esta versión.

${ }^{8}$ La obra con el título Pro ecclesiasticae unitates defensione fue escrita entre septiembre de 1535 y marzo de 1536, e impresa en Roma en 1539. Tomamos el relato de la traducción al inglés: Pole, Reginald, Pole's Defense of the Unity of the Church (1539, trad. inglesa, Westminster MD, 1965), pp. 217-227.

${ }^{9}$ El texto original se conserva en el archivo inglés: P.R.O. Baga de Secretis, Pouch 7, Bundle 3, m. 7. Fue publicado en 1932, como apéndice a la biografía de Moro de Harpsfield: cfr. Sir Thomas More's Indictment, en HarPSField, Nicholas, The Life and Death of St. Thomas Moore, Knight, sometymes Lord High Chancellor of England (London, 1932, reimp. 1963), Apéndice III, pp. 269-276. Lo citamos como Sir Thomas More's Indictment, seguido de la página de esta edición.

${ }^{10}$ El texto relativo al juicio de Tomás Moro es reproducido por Reynolds, E. E., One of Thomas More's Judge, en Moreana, 54 (1977), pp. 27-29.

${ }^{11}$ La edición moderna de las cartas de Tomás Moro es la efectuada por Elizabeth Frances Rogers en 1947: MoRo, Tomás, The Correspondence of Sir Thomas More (Rogers, Elizabeth F., edit., Princeton, 1947). De la misma editora existe una selección: Moro, Tomás, St. Thomas More: Selected Letters (Rogers, Elizabeth F. edit., 2a edic., New Haven - London, 1967). En castellano, con notas y comentarios, existen dos recopilaciones realizadas por Álvaro de Silva: Moro, Tomás, Un hombre solo. Cartas desde la Torre (Silva, Álvaro de, edit., Madrid, 
Las segundas fuentes que ocupamos son las primeras biografías que incluyen el juicio y muerte del biografiado. La primera de ellas es del yerno de Moro, abogado también, William Roper, que fue escrita alrededor de 1556, y sólo publicada por primera vez en $1626^{12}$. Roper, en realidad había puesto por escrito sus recuerdos para ayudar a Nicholas Harpsfield a elaborar una biografía detallada de su suegro. Harpsfield llevó adelante su propósito, y se benefició, además del manuscrito de Roper, de los testimonios de los parientes y conocidos de Moro que se encontraron con él en el exilio en la ciudad de Lovaina, hasta la ascensión al trono de la católica María Tudor en 1553. Tituló su obra Life and Death of sir Thomas More, pero al morir la reina María y llegar al trono Isabel I, el libro quedó inédito, y sólo vino a ser impreso en $1932^{13}$. La tercera biografía de Moro fue escrita en latín por Thomas Stapleton, quien también alcanzó a conocer a algunos parientes y conocidos de Moro, en especial a Dorothy Colley, la doncella de Margaret Roper, hija preferida del humanista. Fue impresa junto con las biografías de Tomás apóstol y Tomás Becket, con el título de Tres Tohmae, en $1588^{14}$. A estas tres primeras biografías, puede añadirse la Life of sir Thomas More escrita por Cresacre Moro, nieto del biografiado, y que añade detalles conservados en la tradición familiar ${ }^{15}$.

Una tercera línea de fuentes que utilizamos son los específicos, aunque escasos, estudios que se han hecho del juicio de Tomás Moro. Los más importantes son una monografía de E. E. Reynolds, publicada en $1964^{16}$ y un artículo de J. Duncan M. Derret publicado en The English Historical Review, también del año $1964^{17}$. Sobre las formas procesales de los juicios de traición de la época resulta

1990); Moro, Tomás, Un hombre para todas las horas. La correspondencia de Tomás Moro (1499-1534) (Silva, Álvaro de, Madrid, 1998). Un estudio sobre algunas cartas aparece en la obra, traducida del italiano, de SARdaro, Anna, La correspondencia de Tomás Moro. Análisis y comentario crítico-histórico (Pamplona, 2007). Las citas de la cartas que se ocupan en este trabajo se hacen según las versiones castellanas de Álvaro de Silva.

${ }^{12}$ Se publicó con el título The Lyfe of Sir Thomas Moore, Knighte: A Mirror of Virtue in Worldly Greatness. Usamos la traducción castellana de Álvaro de Silva: cfr. Roper, William, La vida de Sir Tomás Moro (trad. castellana, 2a edición, Navarra, 2001).

${ }^{13}$ HarpsField, Nicholas, The Life and Death of St. Thomas Moore, Knight, sometymes Lord High Chancellor of England (London, 1932, reimp. 1963).

${ }^{14}$ La biografía de Moro de Stapleton sólo vino a ser traducida y publicada en inglés por Philip E. Hallet en 1928: cfr. STAPLETON, Thomas, The Life and Ilustrious Martyrdom of Sir Thomas More (Part. III of 'Tres Thomae', printed as Douai, 1588) (trad. Philip E. Hallett, Chicago, 1928, reimp. 2009).

${ }^{15}$ Cresacre Moro fue hijo de Thomas More, hijo de John More, el único hijo varón de Tomás Moro. El manuscrito de la biografía fue encontrado entre los papeles de su hermano sacerdote Thomas More cuando éste murió en Roma en 1625, pero los estudiosos han determinado que su autoría corresponde a Cresacre. Fue publicada aún como obra de su hermano Thomas en 1726. En 1828 se hizo una nueva edición al cuidado de Joseph Hunter, en la que se establece la autoría de Cresacre: cfr. Moro, Cresacre, The Life of Sir Thomas More (London, 1828, reimp. 2010).

${ }^{16}$ Reynolds, E. E., The Trial of St. Thomas More (Great Britain, 1964).

${ }^{17}$ Hemos consultado el artículo en la recopilación de estudios sobre Moro editada en 1977 por Sylvester y Marc'hadour: Derret, J. Duncan M., The Trial of Sir Thomas More, en Sylvester, R. S. - Marc'Hadour, G. P. (editores), Essential Articles for the Study of Thomas More (Hamden, Connecticut, 1977), pp. 55-78. 
inprescindible la obra de John Bellamy, publicada en $1979^{18}$.

Finalmente, nos hemos nutrido de los análisis y reflexiones que hacen sobre el juicio de Moro los biógrafos modernos, que son abundantes. Hemos tenido en cuenta la biografía de Chambers (1935), que es la que inaugura el nuevo entusiasmo por la figura de Moro en nuestra época ${ }^{19}$, la de Andrés Vásquez de Prada (1966), sin duda la mejor redactada en castellano ${ }^{20}$, la reflexiva versión del historiador alemán, Peter Berglar $(1978)^{21}$. la de Richard Marius $(1985)^{22}$, con una aproximación revisionista respecto de las tesis moreanas clásicas, y las más recientes de James Monti ${ }^{23}$, Peter Akroyd (1998) ${ }^{24}$ y John Guy $(2000)^{25}$. Para la datación y la cronología de los acontecimientos nos hemos aprovechado de la monumental obra de Germain Marc'Hadour ${ }^{26}$ y para el contexto histórico y los documentos más importantes nos ha servido la magnífica edición del libro Viva Rex!', publicado para difundir y conservar la exposición realizada en 2009 al conmemorarse los 500 años de la ascensión de Enrique VIII al trono de Inglaterra ${ }^{27}$.

Ha parecido imprescindible para comprender más plenamente el proceso mismo, observar la evolución de los acontecimientos desde que Moro renuncia al cargo de lord canciller (II), y de qué manera su actitud, aunque nunca protestara públicamente contra la política de ruptura con Roma que seguía el gobierno, fue crecientemente estimada como contraria a los intereses de Enrique VIII (III). No fue sencillo encontrar imputaciones que pudieran neutralizar la influencia del ex-canciller, pero los intentos fueron incrementándose hasta lograr incluir el nombre de Moro en el proyecto de ley de proscripción contra la Monja de Kent y sus cómplices (IV). Al fracasar esto último, no quedaba otra que comenzar a promulgar leyes que exigieran prestar juramentos de adhesión. Moro cayó en prisión, pero adoptó una estrategia inesperada para el gobierno: se negó a jurar pero también a decir las razones por las cuales no lo hacía, invocando solamente que acceder al juramento sería proceder contra su conciencia y poner en peligro su alma (V). Una ampliación de una ley de traiciones fue necesaria para lograr cargos contra Moro que pudieran ser suficientes para conducirlo al patíbulo (VI). Una conversación "poniendo casos", al estilo de los abogados, que suscitó el abogado

\footnotetext{
${ }^{18}$ Bellamy, John, Tudor Law of Treason. An introduction (Toronto y Buffalo, 1979).

${ }^{19}$ Chambers, R. W., Thomas More (5a edición, U.S.A., 1973). La primera edición es de 1935.

${ }^{20}$ VÁsQuez de Prada, Andrés, Sir Tomás Moro, Lord canciller de Inglaterra (Madrid, 1966). En este trabajo utilizamos la 6a edición (Madrid, 1999).

${ }^{21}$ Usamos la traducción española: Berglar, Peter, La hora de Tomás Moro. Sólo frente al poder (trad. cast., Madrid, 1993).

${ }^{22}$ Marius, Richard, Thomas More (New York, 1985).

${ }^{23}$ Monti, James, The King's Good Servant, but God's First. The Life and Writtings of St. Thomas More (San Francisco, 1997).

${ }^{24}$ A Kroyd, Peter, The Life of Thomas More (Chatto \& Windus, London, 1998). Usamos la traducción al español: Tomás Moro (trad. castellana, Barcelona, reimp. 2004).

${ }^{25}$ GuY, John, Thomas More (London, 2000).

${ }^{26}$ Marc'Hadour, Germain, Lunivers de Thomas More. Cronologie critique de More, Erasme e leur époque (1477-1536) (Paris, 1963).

${ }^{27}$ Schwarz, Arthur L. (editor), Vivat Rex! An Exhibition Commemorating the 500th Anniversary of the Accesion of Henry VIII (New York, 2009).
} 
del rey Richard Rich convenció a las autoridades de tener evidencia suficiente para llevar a juicio al prisionero. Es el día $1^{\circ}$ de julio de 1535 , y comenzaba el famoso juicio. Trataremos de analizarlo en detalle, siguiendo las fuentes y las interpretaciones más verosímiles, con referencia a quienes oficiaron de comisionados ("oyer et terminer") y los que obraron como jurado (VII). Reconstruimos el orden plausible del proceso, que se fundó sobre cuatro cargos principales expuestos por escrito en la acusación, cuyo texto se conserva. Los tres primeros cargos fueron respondidos magistralmente por el acusado y no pudieron construir un caso en su contra (VIII). El cuarto cargo, la conversación entre abogados, reafirmado con único testimonio de su interlocutor, pese a los esfuerzos dialécticos y los argumentos jurídicos de Moro, tanto respecto de la credibilidad del testigo y la verosimilitud de sus dichos como a la improcedencia jurídica para constituir una imputación suficiente bajo la Ley de Traiciones, fue considerado viable y podía pasarse así a la fase de decisión del jurado (IX). Un cuarto de hora necesitarían solamente los miembros del jurado para arribar al veredicto de culpable. Podría proceder la sentencia y así lo intenta el canciller Audley, pero el antiguo juez estaba decidido a no dejar recurso alguno sin ejercer para que nadie le imputara que deseaba hacer de mártir. Moro pidió que se le concediera la palabra para exponer razones en contra de la juridicidad del cargo, cuya efectividad de hecho había dictaminado el jurado. Algunos han pensado que en esta parte, Moro se olvidó del derecho y pasó sencillamente a desahogar un pensamiento hasta entonces refrenado pero que ahora debía exponer para dejar un testimonio de fe a sus contemporáneos y a la posteridad. Discutiremos esta última explicación para determinar si es cierto que Moro en esta gestión ya no obraba como abogado defensor sino como mártir condenado (X). Tan impresionante fue este alegato final, que los jueces titubearon; la sentencia se basó explícitamente en un razonamiento condicional: si la ley era legítima la traición estaba acreditada (XI). La ejecución de la sentencia, conmutada por el rey por la de decapitación, y su cumplimiento, el 6 de julio de 1535, dan cumplimiento a lo resuelto en el proceso (XII).

Un epílogo nos mostrará cómo y dónde fueron sepultados los restos del condenado, y las paradojas de la historia que hizo que los cuerpos de sus principales enemigos: Ana Bolena y Thomas Cromwell, sufrieran el mismo tormento y llegaran a la misma sepultura en la tristemente célebre Torre de Londres.

\section{LA CAÍdA DEL CANCILLER MORO: "MADAME, MY LORD IS GONE"}

Tomás Moro sucedió el 25 de octubre de 1529 como gran canciller de Enrique VIII al cardenal Tomás Wolsey. Wolsey fue destituido de su puesto, a pesar de sus muchos servicios al monarca, por no haber conseguido la anulación del matrimonio entre Enrique y Catalina de Aragón y ser despreciado por Ana Bolena, su familia y sus partidarios, quienes rodeaban ahora al rey. El 6 de octubre de 1529 el cardenal fue oficialmente destituido y más tarde acusado del delito de praemunire $^{28}$. Sólo se libró de la condena por morir en el camino a su prisión en la Torre de Londres (29 de noviembre de 1529).

${ }^{28}$ El estatuto de Preamunire fue aprobado en 1499 bajo Ricardo II y por él se condenada 
Moro no compartía la opinión del rey de que su matrimonio con Catalina era nulo, pero a pesar de ello el rey lo eligió: era un laico, experto jurista, conocido por Enrique desde su infancia y un eficiente y leal servidor público, por lo que podía dar confianza a todos los sectores y liderar el Parlamento que Enrique convocó el 3 de noviembre de 1529. Moro aceptó el cargo a sabiendas de que los tiempos no eran favorables a sus ideas pero no podía ahora desdecirse de lo que pensaba y había dejado escrito en su obra de juventud, la célebre Utopía, en cuanto a "no abandonar la nave en medio de la tempestad"29. Después recordaría como el rey le prometió que no le forzaría a obrar contra su conciencia en la cuestión del matrimonio ${ }^{30}$, y de hecho durante su desempeño como canciller la "grand matter of the King", como se le solía llamar, fue encomendada a otros funcionarios ${ }^{31}$.

a aquellos que llevaban a una Corte extranjera los asuntos que debían conocerse por un tribunal inglés.

${ }^{29}$ En la Utopía el mismo Moro defiende frente a Rafael Hitlodeo, que pensaba que los humanistas no debían implicarse en las Cortes reales, la conveniencia de comprometerse con el bien público: "Si no es posible erradicar de inmediato los principios erróneos, ni abolir las costumbres inmorales, no por ello se ha de abandonar la causa pública. Como tampoco se puede abandonar la nave en medio de la tempestad porque no se pueden dominar los vientos. No quieras imponer ideas peregrinas o desconcertantes a espíritus convencidos de ideas totalmente diferentes. No las admitirían. Te has de insinuar de forma indirecta. Y te has de ingeniar por presentarlo con tal tino que, si no puedes conseguir todo el bien, resulte el menor mal posible": Moro, Tomás, Utopia (trad. castellana, 5a reimp, Madrid, 2004), p. 103.

${ }^{30}$ Moro tenía muy presente la recomendación que Enrique VIII le hizo, cuando entró a su servicio en 1517, de que en todas las cuestiones públicas mirase siempre primero a Dios y después de Dios al rey. Lo recuerda en carta a Cromwell de 5 de marzo de 1534, en la que además relata que, después de haber sido invitado por el rey a examinar la cuestión del matrimonio, este le advirtió que de ninguna manera quería que dijera o hiciera algo contra su conciencia: "me dijo que mi deber era en primer lugar mirar a Dios, y sólo después de Dios a sus intereses": cfr. Moro, T., Correspondencia, cit. (n. 11), p. 281. En consonancia con este documento, William Roper, yerno y primer biógrafo de Moro, cuenta que "poco después" de ser nombrado canciller, el rey le pidió que examinara nuevamente el tema del matrimonio, ante lo cual Moro, arrodillándose, "suplicó humildemente a su Majestad que continuara siendo su gracioso soberano, como siempre lo había sido desde su entrada en el servicio de su Majestad, diciendo que nada en el mundo había sido tan penoso para su corazón como recordar que no era capaz, como tanto lo hubiera querido, con la pérdida de uno de sus miembros, haber encontrado algo con respecto a ese asunto por el que le hubiera sido posible, con su conciencia a salvo, ser útil a la satisfacción de su Majestad [...]"; y le mencionó su propio consejo de siempre mirar primero a Dios y luego al rey. Ante ello, cuenta Roper, "respondió el rey que si no podía en conciencia servirle en este punto, contento se quedaba de aceptar su servicio en otras cosas. Y usando el parecer de otros que le aconsejaban doctamente, cuyas conciencias podían bien estar de acuerdo con ello, continuaría de todos modos su benevolencia para con él y nunca le molestaría su conciencia con ese asunto": Roper, W., cit. (n. 12), p. 40.

${ }^{31}$ En carta a Carlos V, el embajador de España, Eustaquio Chapuys, cuenta, sin embargo, que a fines de 1530 por apoyar la posición de la Reina, el canciller Moro estuvo a punto de ser cesado en su puesto: "The Chancellor, I hear, has spoken so much in the Queen's favor that he has had a narrow escape of being dismissed" (Carta de 20 de septiembre de 1530, en Great Britain. Public Records Office. Calendar of State Papers, Spanish, London, 1882). Más tarde, el 2 de abril de 1531, como presidente ("Speaker") del Parlamento, se vio obligado a exponer ante la House of Lords los informes favorables a la nulidad del matrimonio que el rey había obtenido consultando a varias universidades. Aseguró, además, que Enrique VIII obraba así no por deseo 
Moro se dedicó a sus labores parlamentarias y judiciales en las dos Cortes reales: la "Court of Chancery" y la "Court of Star Chambre".

Permaneció en el cargo por dos años y medio ${ }^{32}$, viendo cómo la política del rey para anular su matrimonio, casarse con Ana Bolena y tener descendencia masculina que pudiera heredar el trono, se convertía progresivamente, gracias a nuevos asesores reales como Tomás Cranmer y Tomás Cromwell, en un rompimiento con el papa ya no sólo como soberano temporal sino como cabeza espiritual de la Iglesia en Inglaterra. Lo que era una cuestión acotada a la supuesta conciencia del rey de vivir en concubinato (por no ser válido el matrimonio con la viuda de su hermano Arturo), se fue expandiendo a la aspiración a tener el poder total sobre la iglesia, los obispos, el clero y todos los fieles de la Iglesia y a una expectativa de incrementar la riqueza del reinado y sus nobles a través de la confiscación de las tierras y propiedades actualmente en manos de conventos, órdenes religiosas y monasterios.

Enrique se dirigió primero al clero a través de la amenaza. Acusó a varios obispos de haber sido cómplices de Wolsey por haberlo aceptado como legado pontificio. Reclamó luego que la Convocation o sínodo de obispos de Canterbury lo declarara cabeza suprema de la iglesia, lo que consiguió pero con la expresión matizada de que ello era "hasta donde lo permita la ley de Cristo": "as far as the law of Christ allows" (11 de febrero de 1531).

El rey siguió insistiendo. El 15 de enero de 1532 se presentó personalmente ante el Parlamento y declaró que, al releer el juramento que hacían los obispos de fidelidad al papa, había "descubierto" que tenía súbditos que sólo lo eran a medias, pues también se sometían a un poder extranjero. La amenaza era directa y clara: o los prelados lo reconocían a él como único soberano y renunciaban a toda obediencia a la jurisdicción del Santo Padre o serían enjuiciados. Los obispos, presididos por el arzobispo de Canterbury, Willam Warham, ya en las postrimerías de su vida, suscribieron el documento denominado muy acertadamente Submission of Clergy ("Sumisión del clero"). En ese documento, la Convocation de Canterbury declaraba a Enrique VIII como suprema cabeza de la Iglesia en Inglaterra sin ningún límite o matización. Era el 15 de mayo de 1532.

Al día siguiente, el 16 de mayo, el arzobispo Warham remitió a Enrique VIII el documento con la sumisión ${ }^{33}$. A las 15:00 horas del mismo día, en el jardín de Whitehall Palace, Enrique VIII junto al duque de Norfolk, Tomás Howard, recibió a Tomás Moro para aceptar su renuncia al cargo de canciller del Reino,

de mujer sino por motivos de conciencia. Se cuidó Moro, sin embargo, de emitir una opinión personal sobre el asunto; cuando se le preguntó lo que pensaba sobre el problema respondió que su opinión se la había dado al rey y que no diría más que eso. Debe considerarse que a la fecha tampoco el papa se había pronunciado sobre la cuestión de la validez del matrimonio, por lo que era un asunto aún legítimamente opinable. Para evitar toda sospecha de deslealtad Moro se negó a recibir una Carta del Emperador Carlos V por medio de su embajador Chapuys, y le pidió a éste que se abstuviera de visitarle (abril de 1531).

${ }^{32}$ Exactamente dos años, seis meses y tres semanas.

${ }^{33}$ Cfr. Marc'Hadour, G., cit. (n. 26), p. 466. 
y recibir el saco de cuero blanco que contenía el gran sello que simbolizaba su función y poder ${ }^{34}$.

A diferencia de Wolsey, Moro no fue destituido sino que le fue aceptada su renuncia, lo que en esos tiempos necesitaba el asentimiento del rey. Moro dice en sus cartas que había estado pidiendo desde antes su salida del gobierno porque tenía problemas de salud que le impedían seguir desempeñando su puesto ${ }^{35}$. Es probable que esta haya sido una explicación acordada y que, si bien las dolencias existían, la verdadera causa de la resignación fuera doble: Moro se daba cuenta que con su presencia ya no podía frenar la política separatista de Enrique y advertía que si se mantenía en el cargo ello se entendería como una legitimación suya a la conducta del gobernante ${ }^{36}$. Por su parte, Enrique no habrá querido enfrentarse directamente a su canciller y enviarlo a prisión como a Wolsey, ya que no tenía motivos para ello, y la excusa de la salud le servía para deshacerse de alguien que ya no le era necesario ni funcional a sus actuales planes.

${ }^{34}$ Cfr. Guy, J. A., The Public Career, of Sir Thomas More (New Haven y London, 1980), p. 201. El sello real será entregado, el día 20 de mayo, a Thomas Audley, quien lo mantendrá como Keeper of the Great Seal, hasta que fuera nombrado gran canciller, como sucesor de Moro, el 26 de enero de 1533.

${ }^{35}$ En carta a Erasmo de 14 de junio de 1532, Moro le cuenta la renuncia a su cargo y lo atribuye a "cierta dolencia de pecho que me tiene atrapado", que los médicos le habrían dicho que no tendría cura rápida, por lo que "ponderando todo esto, me di cuenta de que tendría que renunciar a mi puesto, o de lo contrario sería ineficiente en su descargo, pues sería incapaz de cumplir con las responsabilidades que el puesto lleva consigo, a no ser que pusiera mi vida en peligro; $y$ en caso de muerte, tendría que abandonar tanto el cargo como mi vida": Moro, T., Correspondencia, cit. (n. 11), p. 241. Con igual fecha, escribe a Johannes Cochlaeus, dándole noticias igualmente que por enfermedad, "aunque en la apariencia externa no parezca tan enfermo", ha debido renunciar a su cargo: "mi decisión fue influenciada por un deseo de recuperar mi salud, pero mucho más todavía en consideración al bien común, pues lo hubiera obstruido de muchas maneras si -impedido como estaba por mala salud- yo mismo hubiera sido un impedimento para los asuntos del Estado": Moro, T., Correspondencia, cit. (n. 11), p. 246. Más adelante, Moro le dice a Erasmo que "algunos charlatanes han esparcido por aquí el rumor de que había resignado mi puesto oficial en contra de mi voluntad y de que había guardado en secreto ese detalle": Moro, T., Correspondencia, cit. (n. 11), p. 248. Para contrarrestar ese rumor redactó un Epitafio en el que aprovechó para declarar públicamente la versión oficial: "Sintió la pérdida de su padre, y al reflexionar sobre los cuatro hijos que había criado y sus once nietos, empezó a sentirse viejo en su propia mente. Este sentimiento se intensificó por una grave enfermedad de pecho en la que vio poco después una señal de la cercana vejez. Hastiado con las cosas transitorias de esta vida, presentó su dimisión [...]": Moro, T., Correspondencia, cit. (n. 11), p. 251.

${ }^{36} \mathrm{La}$ acumulación de ambas razones se observa en cómo RoPer cuenta la renuncia de Moro: dice que después de haber tenido que ir a la Cámara Alta del Parlamento a explicar la posición del rey sobre el matrimonio, "temiendo no fuese a ocurrir que se siguieran otros intentos en los que se pudiera ver envuelto debido a su puesto oficial de manera contraria a su conciencia, acudió al duque de Norfolk, amigo íntimo suyo, para que hiciera de intercesor ante el rey y así, pudiera, con el favor de su Majestad, ser relevado de esa pesada carga de su puesto como canciller, y en el que, por ciertas enfermedades de su cuerpo, decía que era incapaz de servir por más tiempo": Roper, W., cit. (n. 12), p. 41. Por eso, señala GuY, J., cit. (n. 34), p. 201, que la renuncia de Moro fue una admisión de su derrota política, pero al mismo tiempo un acto de público desafío. 
La salida de Moro del cargo fue, pues, aparentemente pacífica y satisfactoria para ambas partes. Moro recibió grandes elogios de Enrique VIII ${ }^{37}$ y, a su vez, prometió no inmiscuirse en asuntos públicos y retirarse a una vida de oración y práctica de la piedad personal y familiar ${ }^{38}$.

A pesar de que aparentemente Moro seguía gozando del favor del rey, era consciente de que su situación era muy distinta hasta desde el punto de vista económico. Con su característico humor, Moro hizo ver a su mujer Alice el cambio de situación, según una anécdota que relata Roper. Cuenta su yerno, que mientras era Canciller cuando terminaban los servicios en la Iglesia uno de sus servidores se acercaba al banco de su mujer para avisarle: "Señora, mi señor se ha ido". El primer día de fiesta después de la renuncia a su cargo, no teniendo ya servidores, se acercó el mismo al banco de Alice y haciéndole una revencia le dijo: "Señora, ¡mi señor ha desaparecido!”: “Madame, my lord is gone” 39.

${ }^{37}$ Lo recuerda el mismo Moro en carta a Enrique VIII de fecha 5 de marzo de 1534: cfr. Moro, T., Correspondencia, cit. (n. 11), pp. 273-274. Roper lo reitera diciendo que Enrique recibió el sello en sus manos "con cortesía, agradeciendo y alabando su valioso servicio en ese puesto" y prometiéndole que "cualquier petición que en adelante le hiciera, bien fuera en algo referente a su honor... o en algo perteneciente a su provecho, encontraría siempre en su Alteza un señor bueno y muy bien dispuesto": Roper, W., cit. (n. 12), p. 42. Moro recibió también los elogios públicos del duque de Norfolk y de su sucesor Thomas Audley. Cuando el nuevo canciller abra en nombre del rey la $5^{\text {a }}$ sesión del Parlamento rendirá un homenaje a su antecesor; Moro, sin embargo, no estaba presente ya que no era parlamentario: cfr. Marc'Hadour, G., cit. (n. 26), p. 477.

${ }^{38}$ En carta a Enrique VIII de 5 de marzo de 1534, Moro le agradece haberle dado permiso "para dedicar el resto de mi vida, ahora que empieza esa edad tardía, para proveer por mi alma en servicio de Dios y para rezar por vos en servicio de su Majestad": Moro, T., Correspondencia, cit. (n. 11), p. 273. En el Epitafio que Moro preparó después de su renuncia alude a esta intención de dedicarse a su vida interior: "[...] Hastiado con las cosas transitorias de esta vida, presentó su dimisión, y por la gracia sin igual del más indulgente Soberano (al que Dios sonría con su favor en todas sus empresas), alcanzó por fin el destino que casi desde su niñez había sido el objeto de sus anhelos: disponer de los últimos años de su vida para sí mismo de modo que pudiera poco a poco retirarse de los asuntos de este mundo y contemplar la eternidad de la vida ventura": Moro, T., Correspondencia, cit. (n. 11), p. 251. Al parecer, en este propósito él incluía tareas intelectuales para defender la fe católica impugnada por los escritos protestantes; en carta de 14 de junio de 1532, dice a Johannes Cochlaeus, que, después de renunciar a su cargo, "me he propuesto dedicar a tareas intelectuales y a Dios este tiempo libre que con tanta generosidad se me ha concedido, a petición mía, por la amable compasión de nuestro muy ilustre soberano": cfr. Moro, T., Correspondencia, cit. (n. 11), p. 246.

${ }^{39}$ Roper, W., cit. (n. 12), p. 44. Stapleton, T., cit. (n. 14), p. 139, complementa la anécdota haciendo ver que esta fue la forma en que Madame Alice, que gozaba de un lugar privilegiado en la Iglesia como mujer del Lord canciller, se enteró de la pérdida de posición de su marido, y que al principio pensó que era otra de las bromas de su marido, por lo que Moro tuvo que decirle: "Hablo seriamente y es como yo digo: mi Lord canciller se ha ido y no estará más aquí". 


\section{La REVOLUCión POLÍtico-Religiosa de EnRiQue VIII y la ACTITUd DE Moro: "I WILl PROVIDE THAT THEY SHALL NEVER DEFLOWER ME"}

La ruptura de Enrique VIII con Roma y el poder asumido como soberano no sólo temporal sino espiritual para todos los cristianos de Inglaterra, ha sido caracterizada como una propia revolución ${ }^{40}$. Es efectivo que Enrique en sus comienzos consideró al papa como un aliado y llegó a recibir de Clemente VII el título de Defensor de la Fe por el libro que escribió en contra de la doctrina luterana de los sacramentos, y que luego se fue distanciando de él al ver que no prosperaba su petición de que se invalidara el matrimonio con Catalina de Aragón. Pero posteriormente, aprovechó esta circunstancia para transformar completamente la forma de relación entre la Corona y las autoridades de la Iglesia y para asumir un poder total que ningún rey inglés ante que él tuvo. Se trató, por tanto, de una revolución no masivamente violenta (aunque se ejecutó sin piedad a todos quienes se atrevieron a oponerse), legalista (se utilizó al Parlamento, suficientemente dócil a los deseos reales, ya sea por la selección de sus integrantes o por su amedrentamiento con amenazas de ser enjuiciados como traidores) y aristocrática y no popular. Fue el rey y sus principales nobles los que la llevaron a cabo, ante la resistencia y resignación del pueblo que conservaba sus tradiciones religiosas y no tenía ninguna pretensión de liberarse del supuesto "yugo" romano. De hecho, en la Inglaterra de la época, las doctrinas de Lutero no tuvieron mayor eco y fueron perseguidas incluso por Enrique VIII después de su ruptura con Roma sobre todo por negar la presencia real de Cristo en la eucaristía, que el rey inglés siempre defendió ${ }^{41}$.

La revolución se había ya iniciado bajo la Cancillería de Moro, hasta lograr la "Sumisión del Clero" y que asumiera como arzobispo de Canterbury, incluso con la autorización del papa, Tomás Cranmer. El primer encargo que el rey dio al nuevo arzobispo fue juzgar la validez de su matrimonio. No obstante, Enrique y Ana Bolena no quisieron esperar la anulación para contraer matrimonio, al parecer porque la aspirante a nueva reina estaba en estado de gravidez y había que procurar la legitimidad del hijo. Así fue como el matrimonio se celebró en secreto el día 25 de enero de 1533. La sentencia del arzobispo Cranmer para declarar la nulidad del matrimonio entre Enrique y Catalina fue emitida sólo el 23 de mayo de ese año y cinco días más tarde (el 28 del mismo mes) el mismo Cranmer declaró la validez del matrimonio entre Enrique y Ana. Catalina pasaba así a ser la "princesa viuda” de Arturo y Ana Bolena se convertía en reina de Inglaterra. Su coronación fue realizada solemnemente el día $1^{\circ}$ de junio de 1533.

Moro no perdió inmediatamente el favor del rey. Siguió percibiendo su renta como consejero real y, formalmente, siguió siéndolo aunque no era llamado al

\footnotetext{
${ }^{40}$ Según Marius, R., cit. (n. 22), p. 433, la aprobación de la Ley de Restricción de las apelaciones constituyó una verdadera revolución.

${ }^{41}$ Es paradójico que el mismo Lutero fuera de opinión de que el matrimonio entre Enrique y Catalina de Aragón era legítimo y válido: cfr. WABUDA, Susan, The Reformation of the English Church under Henry VIII, en Schwarz, Arthur L. (editor), Vivat Rex! An Exhibition Commemorating the 500th Anniversary of the Accesion of Henry VIII (New York, 2009), p. 36.
} 
Consejo $^{42}$. Cumplió su promesa de retirarse a la vida privada, pero consideró un deber hacer frente a los escritos anticatólicos que se estaban divulgando ahora con la tolerancia o la simpatía de quienes habían accedido al poder con el partido de los Bolena ${ }^{43}$.

Así, escribió la Letter against John Frith (diciembre de 1532) ${ }^{44}$ y elaboró una extensa respuesta a la réplica que William Tyndale había hecho de su obra $A$ Dialogue concerning Heresies defendiendo su traducción al inglés de la Biblia. Compuso los tres primeros libros de la respuesta en marzo de 1532 y los cinco restantes en 1533, dando lugar así a su Confutation of Tyndale's Answer. De ese año son también su propia defensa frente a los ataques que le acusaban de abusos de poder contra los herejes: The Apology of sir Thomas More (abril de 1533), y otros escritos polémicos: The Debellation of Salem and Bizance (octubre de 1533) y The Answer to a Poisoned Book (diciembre de 1533).

Esta labor de defensa de los principios católicos no fue del agrado al rey, y menos de su nueva esposa que se inclinaba claramente por las ideas protestantes. Se dice que ella le proporcionó al rey las obras de Tyndale y de Fish ${ }^{45}$. El quiebre con la política reformista de Enrique VIII se hizo evidente cuando Moro no asistió a la ceremonia de coronación de la reina Ana. No se trató de un descuido ni de una inadvertencia sino de un acto previamente reflexionado. Temiendo por su integridad, tres obispos, amigos suyos, lo incitaron a que concurriera a la ceremonia e incluso le regalaron dinero para que se comprara ropa apropiada. Moro, aunque aceptó sin escrúpulos el donativo, se negó a acceder y les contó el relato de un emperador al que se le preguntó qué hacer frente a una muchacha a la que debía castigarse según una ley que, sin embargo, eximía de responsabilidad a las doncellas vírgenes. El emperador encontró un fácil expediente: “¡Sea primero desflorada y así podrá luego ser devorada!" ${ }^{46}$. La aplicación de la historia al caso

${ }^{42}$ Marc'Hadour, G., cit. (n. 26), p. 467, sostiene que durante este tiempo fue marginado a las puras funciones judiciales como Ministro de la Equidad. De hecho, y hasta poco antes de su encarcelamiento, siguió percibiendo una pensión de 100 libras anuales.

${ }^{43}$ En realidad con ello proseguía una labor, que le había sido encomendada por los mismos obispos, de leer y refutar los escritos que propalaban doctrinas luteranas y herejías contra la fe católica. Antes de ser nombrado canciller ya había publicado A Dialogue concerning Heresies (junio de 1529) y Supplication of Souls (septiembre de 1529). En el primero se explayaba sobre la mayoría de las ideas heréticas que circulaban en esos años del surgimiento del protestantismo; en el segundo hacía frente al libro de Simon Fish titulado Supplication for the Beggers, en el que se hacía un feroz ataque al clero acusándolo de acopiar riquezas con la falsa pretensión de que limosnas y sufragios podían ayudar las almas de los difuntos. Durante su cancillería se publicaría una segunda edición de A Dialogue concerning Heresies (mayo de 1531).

${ }^{44}$ Marc'Hadour, G., cit. (n. 26), p. 471, anota que, como la obra de Frith había circulado como manuscrito, Moro hizo imprimir la suya por W. Rastell, el 7 de diciembre de 1532, pero no la puso a la venta, para evitar dar más publicidad al escrito que impugnaba. Sólo en diciembre de 1533, cuando publique su An Answer to the firts part of the poisoned book, autorizará la venta de la Letter against Frith: cfr. MARC'HADOUR, G., cit. (n. 26), p. 485.

${ }^{45}$ Le regaló copias de los libros de Tyndale, Obedience of the Christian Man, y de Fish, Supplication for the Beggers: cfr. WABUDA, S., cit. (n. 41), p. 36.

${ }^{46}$ El hecho lo cuenta Roper, W., cit. (n. 12), p. 46. Aunque no aparece la referencia es claro que Moro se refiere a un episodio que Tácito atribuye a Tiberio. Después de la caída 
de Moro era evidente: "Bien, señores míos, [...] no está en mi poder el que me devoren a mí o no. Pero con la ayuda de Dios que es mi buen Señor, ¡voy a tener yo mucho cuidado de no ser jamás desflorado! ("Now muy lords, quoth he, it lieth not in my power but that they may devour me; but God being my good lord, ;I will provide that they shall never deflower me?')" ${ }^{27}$.

Aunque se ha sugerido que Moro integró o fue líder de una oposición concertada a la nueva política que comenzaba a implementar Enrique VIII y sus actuales consejeros $^{48}$, las mismas declaraciones de Moro y la evidencia disponible muestra que no hubo tal concertación y que la actitud de Moro se dirigió siempre a servir lealmente al rey mientras se le permitiera mantener su fidelidad a Cristo y a la unidad de la Iglesia Católica, deberes que él considera prioritarios ${ }^{49}$.

\section{Primeras tentativas de encausar a Moro: "QUOD DIFFERTUR NON AUFERTUR"}

\section{Acusaciones de corrupción.}

Una vez que hubiera dejado su cargo, Tomás Moro tuvo que enfrentar algunos intentos de enjuiciarlo con acusaciones de soborno. Al parecer, el más serio de ellos fue tramado por Tomás Bolena, padre de Ana, que como conde de Wiltshire integraba el Consejo del rey. Se refería a la aceptación por parte del entonces canciller de una copa de oro entregada como recompensa por una de las partes por haber decidido un juicio a su favor. La parte afectada reclamó al rey y éste ordenó que se citara a Moro para que compareciera ante el Consejo real ${ }^{50}$. Al comparecer Moro declaró que era efectivo que le habían llevado la copa, mucho después del decreto resolutivo, y como regalo de Año Nuevo. Pensando que la confesión lo incriminaba, Tomás Bolena, manifestó: “¿Mirad, ¿̨no os dije, señores, que encontraríamos la verdad en este asunto?" 51 , pero Moro pidió que le escucharan con imparcialidad la totalidad de la historia y contó cómo, si bien por cortesía y ante la insistencia de la mujer, había recibido la copa, inmediatamente después había

de Sejano el emperador Tiberio ordenó la muerte de los hijos de aquel, entre ellos una niña inocente que preguntaba cuál era su falta y sugería que se la podía castigar con el azote de los niños; Tácito relata: "Cuentan los historiadores de la época que, como se consideraba inaudito que una doncella sufriera la pena capital, el verdugo la violó al tiempo que le ponía la cuerda [...]": TÁcito, Cornelio, Anales VI,9 (trad. castellana, Madrid, 1979), p. 341.

${ }^{47}$ Roper, W., cit. (n. 12), p. 47. Los obispos que trataron de convencer a Moro, según Roper, fueron los de Durham, Cuthbert Tunstall; de Bath, John Clerk; y de Winchester, Stephen Gardiner.

${ }^{48}$ Así, Elton, G. R., Sir Thomas More and the opposition to Henry VIII, en Sylvester, R. S. y Marc'Hadour, G. P. (edits.), Essential Articles for the Study of Thomas More (Hamden, Connecticut, 1977), pp. 79-91.

${ }^{49}$ Bernard, G. W., The King's Reformation. Henry VIII and the Remaking of the English Church (New Haven y London, 2005), pp. 125-151.

${ }^{50}$ El pleito se había trabado entre los comerciantes Parnell y Vaugham. Parnell se quejó ante el rey de que Moro había aceptado de manos de la mujer de Vaughan una copa de oro "bien grande y hermosa”: Roper, W., cit. (n. 12), p. 49. Roper señala respecto de Tomás Bolena, Lord de Wiltshire, "que por odio de su religión era el promotor de este litigio".

${ }^{51}$ Roper, W., cit. (n. 12), p. 49. 
ordenado a su criado que la llenara con vino, lo bebió a la salud de la señora y ésta brindó también por él, tras lo cual le dijo que con la misma libertad con que su marido le había regalado la copa ahora él libremente se la daba a ella para que se la diera a su marido como regalo de Año Nuevo. La mujer, resignada, la recibió. La historia fue confirmada por la mujer y otros testigos que así lo declararon. Con ello, dice Roper, "así la enorme montaña se tornó en una pequeña topera" ${ }^{2}$. Dos intentos más de incriminarlo por abuso de poder o corrupción fueron también desvirtuados completamente por Moro ${ }^{53}$.

\section{Acusaciones de escribir contra el rey.}

Una nueva forma de inculpar a Moro fue la de ver en sus escritos en defensa de la fe católica un propósito de obstaculizar la política gubernamental de fortalecer el poder soberano del rey. En verdad, sucedía que el gobierno estaba interesado en difundir la doctrina del cesaropapismo en Inglaterra y una forma de lograrlo era promocionando obras que lo justificaban. Una parte importante tuvo en esta construcción intelectual el famoso jurista y abogado, colega de Moro, Christofer Saint German ${ }^{54}$, el que en 1531 añadió un apéndice a su famosa obra Doctor and Student, las New Additions, por el que defendía la primacía del Derecho inglés por sobre las leyes canónicas y eclesiásticas y propiciaba su reforma por medio de estatutos legales adoptados por la más alta autoridad del reino: "the king-in-parliament" ${ }^{55}$. A fines de 1532, o a principios de 1533, Saint German

${ }^{52}$ Roper, W., cit. (n. 12), p. 49.

${ }^{53} \mathrm{Al}$ caso Parnell, Roper agrega dos más bastante parecidos: el caso de la viuda Crocker que, supuestamente en recompensa por un decreto de Cancillería que la había favorecido en contra del Lord de Arundel, le ofreció un par de guantes y cuarenta libras de ángeles como regalo de Año Nuevo. Moro sólo aceptó los guantes pero rechazó el oro. El segundo caso es de Gresham que, teniendo una causa pendiente en la Cancillería, le envió como regalo de Año Nuevo una copa de oro. Esta vez Moro innovó la solución, ya que le gustó el estilo de la copa, y así mandó que le trajeran una copa de mayor valor (aunque en su opinión de inferior estilo), y ordenó al mensajero que se la entregara a Gresham como recompensa: cfr. Roper, W., cit. (n. 12), p. 50. No es seguro, sin embargo, si estos casos fueron llevados a juicio, o fueron maledicencias que se dijeron contra Moro, y que él debió aclarar para mantener su prestigio de juez probo.

${ }^{54}$ Saint German, a la sazón de 72 años, disfrutaba de una extensa fama por su obra llamada abreviadamente Doctor and Student, dos diálogos sobre el Derecho Inglés, publicados en 1528 y 1530 . El libro tuvo gran éxito y se convirtió en el texto clásico para los estudiantes de Derecho, no sólo en los períodos Tudor y Stuart sino hasta las reformas victorianas de 1870. Cfr. GuY, John, Thomas More and Cristopher St. German: The Battle of the Books, en Moreana, 21 (1984) 83-84, pp. 8-9.

${ }^{55}$ Según GuY, J., cit. (n. 54), pp. 9-10, Saint German, al formular en las New Additions una sucesión de argumentos a favor de la omnicompetencia de los estatutos legales y al considerar que el "rey en Parlamento" era el más alto soberano sobre el pueblo, con responsabilidad no sólo por los cuerpos sino por las almas de sus súbditos, fue, más que Cromwell, el ideólogo de la reforma revolucionaria de Enrique VIII: "Cristopher St. German, dos años antes de la ley de apelaciones, y tres antes de la ley de supremacía, fue el primer caballero inglés en articular la teoría de la soberanía del rey-en-parlamento, la teoría que erigió la Reforma inglesa y que ha prevalecido en el porvenir, salvo durante los once años de la República inglesa y el Protectorado Cromweliano". 
publicó, anónimamente, una obra donde se alentaban reformas para someter al clero y la Iglesia al poder del rey: A Treatise concerning the Division between the Spirituality and Temporality. Viendo aquí un ataque a la Iglesia, al clero y a los procedimientos de los tribunales eclesiásticos contra los herejes, Moro se sintió obligado a contestar con un libro en el que aprovechaba para justificar su propia conducta en defensa de la fe y contra las doctrinas heréticas mientras fue canciller; por ello la tituló The Apology of sir Thomas More. Frente a la Apology, Saint German escribió una respuesta, también anónima, en forma de diálogo titulada Salem and Bizance (septiembre de 1533). Rápidamente Moro tomó de nuevo la pluma y contestó con The Debellation of Salem and Bizance (octubre de 1533) ${ }^{56}$. A fines de 1533 aparece también la segunda parte de la Confutation of Tyndale's Answer (libros 4 a 8$)^{57}$.

Hasta este momento, Moro había escrito contra doctrinas que eran consideradas heréticas pero que no tenían el apoyo oficial del gobierno. Algo distinto ocurrió cuando, en diciembre de 1533, se publicó el panfleto que llevaba por título Articles devised by the Whole Consent of the King's Most Honourable Councily, mejor conocido por The Book of Nine Articles: el libro de los nueve artículos. El escrito trataba duramente al papa Clemente VII: decía que no tenía más poder que cualquier otro obispo fuera de su diócesis y lo acusaba de herejía por contradecir el decreto Sacrosancta del Concilio de Constanza $(1415)^{58}$. Por la misma época, Moro imprimió en la imprenta de su sobrino William Rastell un libro titulado An Answer to the firts part of the poisoned book. Inmediatamente, los enemigos de Moro alegaron que el excanciller había escrito contra el libro autorizado por el Consejo del rey y, por tanto, contra el mismo rey. Tomás Cromwell le hizo saber a Moro, por medio del sobrino de éste, William Rastell, que corría el rumor de que había escrito una refutación al libro del Consejo real. Moro, por carta de $1^{\circ}$ de febrero de 1534 , le hace ver a Cromwell que el libro escrito por él fue una respuesta a una obra anónima titulada The Supper of The lord y que negaba la doctrina católica de la eucaristía ${ }^{59}$. Suponía que parte de la confusión se habría debido a que su libro fue fechado por el impresor en 1534, cuando en realidad el escrito ya estaba en venta antes de Navidad de $1533^{60}$.

\footnotetext{
${ }^{56} \mathrm{El}$ libro de Moro fue contestado con la obra The Additions of Salem and Bizance, publicada por Saint German a mediados de 1534. Moro ya estaba prisionero en la Torre y no replicó.

${ }^{57} \mathrm{La}$ obra fue impresa por William Rastell pero inconclusa. El libro 9, conteniendo una recapitulación de todo el escrito, sería sólo impreso en 1557, cuando se editaron por primera vez las obras completas de Moro.

${ }^{58}$ Cfr. SChWARZ, A., cit. (n. 27), No 86, pp. 147-148.

${ }^{59}$ El título completo del libro de Moro era The Answer to The First Part of the Poisoned Book Wich a Nameless Heretic Hath Named the Supper of the Lord. El autor del libro impugnado por Moro era George Joy.

${ }^{60}$ Carta a Tomás Cromwell de 1 de febrero de 1534, en Moro, T., Correspondencia, cit. (n. 11), pp. 258-261. Niega Moro terminantemente que tuviera la intención de escribir contra el libro preparado por el Consejo: "por tanto, siendo algo que ni hice ni jamás pretendí hacer, os suplico de corazón que si averiguáis de alguien que por mala intención o por imprudencia afirme tal cosa de mí, seáis bueno conmigo y me ayudéis a resolver el asunto con esa persona" (p. 260).
} 
La exculpación de Moro era legalmente indisputable, pero para Enrique VIII y sus consejeros el excanciller había asumido una posición contraria a la política gubernamental al polemizar con los escritos de Saint German, si bien pretextando que desconocía su autoría y el respaldo gubernamental a sus obras ${ }^{61}$. Es obvio que Moro sabía el riesgo que corría pero pensaba que no salía del terreno privado al que se había retirado por el hecho de defender la ortodoxia católica contra libros que se presentaban como anónimos. Es probable, sin embargo, que Enrique pensara que, más allá de formalismos, Moro había roto su promesa y ya no era de fiar ${ }^{62}$. Había que esperar un nuevo caso, en el cual pudiera enrostrarse a Moro su ingrata deslealtad, a los ojos del rey. Este no tardaría en llegar.

\section{El caso de la "monja de Kent": Moro incluido en un proyecto de ley de pros- cripción.}

Tras la sumisión del clero de 1532, la política de Tomás Cromwell había conseguido un clamoroso triunfo, pero quedaban todavía muchos opositores que se mantenían a la expectativa fuera de Londres, esperando un nuevo giro de Enrique o un avenimiento con el emperador Carlos V y el papa. Era necesario aplastar la oposición con medidas de fuerza y amedrentamiento, pero que tuvieran visos de legalidad para evitar el desprestigio del poder real. Se discurrió, así, el enjuiciamiento de Isabel Barton y sus seguidores ${ }^{63}$. Barton, que había sido sirvienta en una parroquia de Aldington, después de curar de una extraña enfermedad comenzó a decir que tenía visiones y recibía revelaciones divinas. El arzobispo de Canterbury, William Warham, le aconsejó ingresar a una orden religiosa y ella eligió el convento de benedictinas del Santo Sepulcro de la diócesis. Sus inspiraciones y mensajes revelados continuaron y pronto se formó a su alrededor un grupo de seguidores. $\mathrm{Su}$ fama de santidad se expandió y fue conocida como la "holy maid of Kent", la santa doncella de Kent ${ }^{64}$. Varios nobles concurrieron a verla y consultarla, se

${ }^{61}$ GuY, J., cit. (n. 54), pp. 17-20, sostiene que Moro no podía desconocer la autoría de las obras de Saint German y el apoyo a ellas por parte del gobierno, las cuales fueron impresas por el impresor del rey, Thomas Barthelet, pero para evitar que se le imputara que estaba incursionando en temas públicos mantuvo la idea de que él contestaba a alguien que oficialmente no tenía identidad conocida.

${ }^{62}$ GuY, J., cit. (n. 54), pp. 5-25, defiende esta tesis que contribuye a explicar el cambio de actitud de Enrique VIII, desde la aceptación de la renuncia de Moro en 1532 al intento real de acusarlo como traidor en el caso de la monja de Kent en 1534. Cfr. del mismo autor: GuY, J., cit. (n. 25), pp. 172-173.

${ }^{63}$ Mattingly, Garret, Catalina de Aragón (trad. castellana, 2a edic., Madrid, 1998), p. 441, sostiene que Cromwell no estaba interesado en el ajusticiamiento de una monja loca de Kent, sino "hacer de sus profecías una red en la que atrapar a personas que podían mandar las legiones de este mundo". Con la confesión y ajusticiamiento de la monja podía aterrorizar a todos los partidarios de la reina Catalina y a esta misma (p. 442). BERnARD, G., cit. (49), p. 100 , señala que, aunque Barton adujo tener revelaciones divinas contra el segundo matrimonio del rey, en la medida en que ellas fueron entregadas personalmente al monarca, su actuación puede enmarcarse en la tradición de francos consejos a los monarcas, más que constituir una conspiración política y un llamado a la rebelión, como la presentó el gobierno en su acusación ante el Parlamento y pretendió mostrarla la propaganda de Enrique VIII.

${ }^{64}$ La historia de Isabel Barton, la monja de Kent, ha sido construida sobre la base de las 
entrevistó privadamente con el cardenal Wolsey e incluso el mismo Enrique la recibió al menos dos veces ${ }^{65}$. Entre los mensajes revelados especial importancia se dio a los que señalaban que si el rey abandonaba a Catalina ofendería gravemente a Dios, los que fueron siendo cada vez más sombríos llegando a anunciar que el rey dejaría de serlo si se casaba con Ana Bolena ${ }^{66}$.

Eludiendo un juicio ante los tribunales, Cromwell obtuvo que se presentara, el 21 de febrero de 1534, en la Cámara Alta del Parlamento un proyecto de Bill of Attainder ${ }^{67}$ contra Isabel Barton y sus seguidores ${ }^{68}$, que pretendía castigarlos por sedición y traición ${ }^{69}$. El proyecto mencionaba como inculpados al obispo

versiones de su juicio, ya que no existen fuentes contemporáneas que den una versión más imparcial. Sólo en fragmentos se conserva una relación de su vida contenida en el libro de William Lambard (A Perambulation of Kent: Conteining the Description, Hystoric and Customes of that Shyre), publicado mucho después, en 1576: cfr. SchwarZ, A., cit. (n. 27), No 94, p. 154. Un intento de reconstrucción más objetiva puede verse en BERNARD, G., cit. (n. 49), pp. 87-101. La biografía moderna disponible es la de Neame, Alan, The Holy Maid of Kent: The Life of Elizabeth Barton: 1506-1534 (London, 1971). Puede verse también a WaTT, Daniel, The Prophet at Home: Elizabeth Barton and the Influence of Bridget of Sweden and Catherine of Sienne, en Voaden, Rosalynn (edit.), Prophets abroad. The Reception of Continental Holy Woman en Late-Medieval England (Cambridge, reimp. 1999), pp. 161-176.

${ }^{65}$ Cfr. Bernard, G., cit. (n. 49), p. 90.

${ }^{66} \mathrm{Al}$ parecer, primero Isabel Barton declaró que un ángel le había mandado comunicar al rey que si se casaba con Ana Bolena la venganza de Dios caería sobre él. Más tarde señaló que se le había dicho que, si Enrique persistía en casarse con Ana, un mes después del matrimonio no sería más rey del reino. Cuando Enrique VIII y Ana Bolena viajaron a Calais para encontrarse con Francisco I de Francia en septiembre de 1532, ella declaró que al asistir el rey a Misa un ángel arrebató de manos del sacerdote celebrante la hostia consagrada con la que iba a comulgar Enrique y la llevó a la boca de la misma Isabel Barton, que había sido transportada milagrosamente de Inglaterra a ese lugar de manera invisible. Transcurrido un mes desde el matrimonio de Enrique y Ana en enero de 1533, la monja de Kent reinterpretó su profecía, diciendo que el rey, aunque no había sido derrocado, ya no era rey a los ojos de Dios. Cfr. Bernard, G., cit. (n. 49), p. 89.

${ }^{67}$ El Bill of Attainder era una ley que imponía castigos por subversión o sedición sin necesidad de un juicio previo y que podían ir desde la confiscación de bienes, privación de derechos civiles hasta la muerte. Debe recordarse que en esta época no existía una nítida separación de poderes ni tampoco las garantías del derecho penal moderno. Posteriormente, este tipo de juicio público ante el Parlamento fue abolido: en Estados Unidos su improcedencia es declarada constitucionalmente: "No Bill of Attainder or ex post facto Law shall be passed" (artículo I, sec. 9 ${ }^{a}$, cl. 3). En Inglaterra no ha sido expresamente abolido, por lo que en teoría el Parlamento conservaría este derecho, pero el último caso en que se aprobó una ley de este tipo ocurrió en 1697: cfr. ReYNOLDS, E., cit. (n. 16), p. 62, n. 1.

${ }^{68}$ Se incluyó también a su confesor, Edward Bocking y a otros adherentes: John Richard Dering, Richard Master y Henry Gold, además de dos frailes franciscanos: Hugo Rich y Richard Risby.

${ }^{69}$ Bernard, G., cit. (n. 49), pp. 89-90, señala que, después de lograr la confesión de la monja y sus seguidores y denunciarlos públicamente, mediante un sermón predicado ante la Catedral de Saint Paul el 23 de noviembre de 1533, el gobierno dudó sobre cómo proseguir y finalmente decidió recurrir al expediente del Bill of Attainder, para lo cual sólo necesitaba lograr la mayoría de los parlamentarios, y se evitaban las complejidades de un juicio seguido conforme al common law, en el cual no era seguro que ella hubiera sido encontrada culpable de alta traición. 
de Rochester, John Fisher y al ex canciller Tomás Moro, por haber apoyado y ocultado información sobre el intento de subversión. Muchos nobles debieron comprender con espanto que si se acusaba a Moro y Fisher cualquiera de ellos podía también ser imputado. Pero el rey y Cromwell pudieron comprobar que el diestro abogado que era Moro no estaba dispuesto a que se le condenara sin hacer valer sus derechos y sin pedir que se le escuchara. Inmediatamente escribió en su descargo a Cromwell y al rey, haciendo ver que nunca había apoyado los dichos de la monja y que la única vez que se entrevistó con ella, a petición de los monjes del monasterio de Sión, no le permitió que le contara ninguna de sus revelaciones y sólo le pidió que rezara por él ${ }^{70}$. Como prueba acompañaba copia de una carta que él mismo había dirigido a la monja después de su entrevista, en la que le recordaba que en su entrevista le había dicho que no tenía deseos de oír revelaciones sobre asuntos de príncipes y estado del reino "y de ninguna manera los escucharía"71 y le pedía no hablar "con ninguna persona, sobre todo con laicos, de cualquier tipo de temas que se refieran a asuntos de los príncipes o del estado del reino"72.

${ }^{70}$ Según Chambers, R., cit. (n. 19), p. 296, Moro envió una primera carta a Cromwell antes de ser incluido en el proyecto de ley de proscripción contra Barton y tras ser advertido por Cromwell, a través de su yerno William Roper, que había evidencia de que Moro había estado en comunicación con la Monja y le había proporcionado ayuda y consejo. No obstante, las cartas que se conservan sobre el tema son tres: dos a Cromwell y una al rey. Las dos de Cromwell no tienen data segura pero deben ser posteriores al 21 de febrero de 1534, fecha en la que se presentó el proyecto de ley contra Barton; el texto en castellano puede verse en Moro, T., Correspondencia, cit. (n. 11), pp. 261-262; 263-273. La carta al rey es del 5 de marzo de 1534: Moro, T., Correspondencia, cit. (n. 11), pp. 273-276.

${ }^{71}$ Moro tenía muy presente el caso de Edward Stafford, duque de Buckingham, quien fue acusado y condenado a morir decapitado, en mayo de 1521, por alta traición, por cargos muy ligeros, entre los cuales se encontraba el de haber dado oídos a las profecías de un monje que le aseguraba que tras la muerte de Enrique VIII él le sucedería en el trono. En la carta a Isabel le menciona expresamente este episodio: "Seguro que habréis oído cómo el difunto duque de Buckingham fue movido por la fama de uno que decía ser un santo fraile, y tuvo conversaciones con él que fueron luego, en buena parte, la causa de su destrucción y desheredamiento, y también de gran infamia para la religión": Moro, T., Correspondencia, cit. (n. 11), p. 255. La suerte del duque de Buckingham había impresionado a Moro al punto de que, según se ha sostenido, a este personaje se referiría en su obra inconclusa The last things, cuando al recomendar la consideración de la muerte para evitar la envidia habla de lo absurdo que sería envidiar a "un gran duque" con todas sus pompa, lujos y bienes, que, sin embargo "por alguna traición secreta recientemente descubierta por el rey, este duque sin duda va a ser al día siguiente detenido [...] arrojado a la cárcel [...] el asunto comprobado y él condenado a muerte": cfr. Moro, Tomás, The Four Last Things, en El mISmo, The Four Last Things. The Supplication of Souls. A Dialogue on Conscience (New York, 2002), pp. 44-45; cfr. también traducción española de Álvaro Silva, con el título Piensa la Muerte: Moro, Tomás, Piensa la muerte (trad. castellana, Madrid, 2006), p. 96; cfr. la nota del traductor en p. 162.

${ }^{72}$ Moro, T., Correspondencia, cit. (n. 11), p. 252-255. No hay constancia de la fecha de la carta de Moro a Barton, pero se sugiere que probablemente es de 1533. La implicancia de Moro en el caso de la monja de Kent es analizada por Derret, J. Duncan M., Sir Thomas More and the Nun of Kent, en Moreana, 15-16 (1967), pp. 267-284. Según este autor, Moro corrió conscientemente un gran riesgo al encontrarse a solas con la doncella de Kent, sabiendo que podía ser acusado de traición, pero lo hizo para ayudar a sus amigos los frailes del Monasterio 
Para evitar que Moro se presentara personalmente para defenderse ante el Parlamento $^{73}$, Enrique dispuso que presentara sus argumentos ante una comisión compuesta por Tomas Cranmer, el arzobispo de Canterbury; Tomás Audley, el lord canciller; Tomás Howard, el duque de Norfolk y Tomás Cromwell, el Secretario real ${ }^{74}$. No teniendo mayor destino la imputación de connivencia con la doncella de Kent, se aprovechó para imputar a Moro otros cargos: se dijo que, siendo consejero real, había urgido y engañado al rey para que escribiera su libro en defensa de los sacramentos y en él afirmara la autoridad del papa sobre la Iglesia, contra los escritos de Lutero ${ }^{75}$. Moro sorprendió a la Comisión diciendo que sobre este punto, que parecía ser el más fuerte en su contra, "estoy seguro de que su Alteza el rey, por su honor, nunca me lo imputará"76, pasando a recordar que nunca fue promotor ni consejero del rey en este tema, y que se limitó, una vez terminado, a ordenar y clasificar los asuntos principales contenidos en el libro. Es más, prosiguió: "cuando encontré la autoridad del papa altamente promocionada y poderosamente defendida con sólidos argumentos, le dije a su Majestad: 'Es mi deber recordar a vuestra Alteza sobre una cosa y es la siguiente: el papa, como vuestra Alteza sabe, es un soberano como vos, y en alianza con todos los otros soberanos cristianos. Puede que ocurra después en algún momento que vuestra Alteza y él discrepen sobre algunos puntos de la alianza, de donde pueda resultar una rotura de amistad y la guerra entre los dos. Por lo tanto, me parece que lo mejor sería que ese pasaje sea enmendado y su autoridad tratada de una manera más tenue"'77. Añadió que Enrique se negó terminantemente a alterar lo escrito. $\mathrm{Al}$ insistir Tomás indicando que por la existencia del estatuto de praemunire incluso la responsabilidad espiritual del papa podía entenderse limitada, se negó nuevamente el rey a reducir el reconocimiento del poder del papa, aduciendo que

de Sion que querían que alguien, con la experticia del abogado y político, examinara a Isabel Barton y los previniera de estar dando hospitalidad a una persona falsa o enferma (p. 277). La conclusión de Moro, después de la entrevista, fue favorable a la monja, impresionado por su sencillez y humildad, aunque advirtió que se trataba de una presunción de buena fe que podría ser destruida si se probaba que en realidad era una persona malvada. Al parecer, después de la confesión de la doncella ante el arzobispo Cranmer, Moro cambió su opinión pues la trata con dureza: en su carta al rey se refiere a ella como "the wykked woman of Canterbury" ("la perversa mujer de Canterbury”): cfr. Moro, T., Correspondencia, cit. (n. 11), p. 274.

${ }^{73}$ En su carta a Cromwell, Moro sostenía que confiaba en que nadie le imputaría haber favorecido o apoyado los dichos de Isabel Barton faltando a su lealtad al rey, y que si alguien lo hacía "yo mismo iré a responder y a satisfacer con la verdad, como corresponde a un hombre honrado y leal": Moro, T., Correspondencia, cit. (n. 11), p. 272.

${ }^{74} \mathrm{La}$ comparecencia de Moro ante el Consejo debió tener lugar pocos días antes del 7 de marzo de 1534, fecha en la que el embajador español Eustaquio Chapuys la menciona en una de sus cartas al emperador Carlos V: cfr. Marius, R., cit. (n. 22), p. 453.

${ }^{75}$ Se trata del opúsculo que escribió Enrique titulado Assertio septem Sacramentorum, como respuesta al libro de Lutero, De captivitate Babilónica ecclesiae praeludium, y por el cual el papa Clemente VII le otorgó el título de Defensor Fidei ("Defensor de la Fe"), todo ello en el año 1521.

${ }^{76}$ Roper, W., cit. (n. 12), p. 53.

${ }^{77}$ Roper, W., cit. (n. 12), p. 53. 
había recibido la corona imperial de manos de la Santa $S e^{78}$. Su alegato terminó apelando al rey y señalando a los comisionados que si alguna duda les quedaba al respecto, si su Majestad fuera bien informado de esto, haría memoria y él mismo aclararía totalmente su conducta ${ }^{79}$.

Las respuestas de Moro en vez de disipar la indignación de Enrique la intensificaron, a tal grado que se mostró contrario al consejo de los comisionados de no proseguir la persecución de Moro en el caso de la monja de Kent, dada la falta de evidencia para implicar al ex canciller en las revelaciones contrarias al trono. La diferencia llegó a su punto culminante cuando los Lores, que estaban en la tercera lectura del proyecto de ley contra Barton y sus cómplices, enviaron al rey una petición para saber si sería conforme a sus deseos que se escuchara al acusado en la "Star Chambre" ${ }^{80}$. Los consejeros del rey alegaron que permitir la comparecencia personal de Moro antes los Lores podría significar no sólo su exculpación sino la frustración de todo el caso contra la monja. Enrique replicó que él mismo en persona concurriría también a la Cámara para hacer valer su autoridad. Siguiendo los modos medievales, Audley y los demás comisionados, se hincaron ante Enrique y le imploraron que no perseverara en una intención que podía ser causa de eterno deshonor para él. El rey se dejó convencer, y finalmente el nombre de Moro, no así el de Fisher ${ }^{81}$, fue eliminado en la cuarta lectura del proyecto por parte de la Cámara Alta del Parlamento ${ }^{82}$.

Moro había conseguido liberarse de un nuevo intento de someter su voluntad al poder de Enrique, pero no se hacía muchas ilusiones de que se hubieran terminado los peligros para su persona y familia. De hecho su pensión de consejero real fue dejada de pagar desde este momento ${ }^{83}$. Cuando su hija Margaret le contó que Cromwell le mandaba a comunicar que su nombre había sido eliminado del

${ }^{78}$ Roper, W., cit. (n. 12), p. 54. La alusión de Enrique a la concesión del papa de la corona se refiere a la Bula de 27 de marzo de 1486 por la cual el papa Inocencio VIII reconoció a Enrique VII como rey de Inglaterra: cfr. Reynolds, E., cit. (n. 16), pp. 33-34 y 36.

${ }^{79} \mathrm{La}$ posición de Moro consta también de carta a Cromwell de 5 de marzo de 1534: Moro, T., Correspondencia, cit. (n. 11), pp. 283-287.

${ }^{80}$ Según Marc'Hadour, G., cit. (n. 26), p. 491, el viernes 6 de marzo de 1534, la Cámara de los Lores rechazó aprobar el Bill of Attainder y sugirió respetuosamente al rey que Moro fuera examinado por los Lores en la "Star Chambre".

${ }^{81}$ A pesar de haber escrito a Cromwell y al rey, el obispo Fisher no consiguió que se excluyera su nombre del Bill, y finalmente fue condenado por el Parlamento por no haber revelado lo que la monja le contó. En un principio, fue condenado a prisión pero la pena luego fue reducida al pago de una multa ascendiente a un año de las rentas de su obispado. Cfr. Bernard, G., cit. (n. 49), p. 118; Marc'Hadour, G., cit. (n. 26), p. 490.

${ }^{82}$ Chambers, R., cit. (n. 19), pp. 228-299. Roper, W, cit. (n. 12), p. 56, cuenta que los consejeros, presididos por el canciller Audley le suplicaron de rodillas que no concurriera al Parlamento, "pensando que si era derrotado estando él presente, no sólo animaría a sus súbditos de ahí en adelante a despreciarle, sino que también redundaría su deshonra para siempre por toda la Cristiandad". Consiguieron disuadirle prometiéndole que encontrarían algo más sustancial en su contra que el asunto de la Monja de Kent donde era público que el comportamiento de Moro había sido más digno de alabanza que de reproche.

${ }^{83}$ Así lo relata el embajador español Chapuys en una de sus cartas: cfr. Marius, R., cit. (n. 22), p. 454. Marc'Hadour, G., cit. (n. 26), p. 467, n. 1, señala que la pensión se habría suspendido con su arresto, después de negarse a jurar la Ley de Sucesión (abril de 1534). 
Bill, Moro contestó con una de sus enigmáticas frases: "En verdad, Meg, quod differtur non aufertur", lo que expresa la idea de que lo que se difiere no por eso desaparece ${ }^{84}$.

En efecto, el Bill of Attainder contra la monja de Kent fue finalmente aprobado e Isabel Barton y sus compañeros, fueron ejecutados el 20 de abril de $1534^{85}$. Pero para esa fecha Moro estaba ya en prisión en la Torre.

\section{LA LEY DE SUCESIÓN Y LA PRISIÓN DE MORO: “THE FIELD IS WON”}

La revolución político-religiosa de Enrique VIII, había ya comenzado con la sumisión del clero, y con algunas leyes aprobadas por el Parlamento desconociendo la autoridad del papa. Así en 1532 se aprobó la primera Act in Restraint of Annates, por la cual se suspendió el pago a Roma de las anatas, esto es, de las primeras rentas de los obispados, pero dejando suspendida su ejecución a voluntad del rey por el plazo de dos años. La eliminación completa de las anatas sería aprobada definitivamente por otra ley de 1534. Más significado tuvo la ley de restricción de las apelaciones: Act in Restraint of Appeals (febrero de 1533), que impedía recurrir ante la jurisdicción del papa por las sentencias y decisiones adoptadas en la Iglesia de Inglaterra. El recurso al papa era sustituido por uno para ante el Arzobispado de Canterbury o la Convocation. La ley tenía como objetivo principal evitar la impugnación por parte de Catalina de la sentencia de nulidad de su matrimonio que pronunciaría poco después el arzobispo de Canterbury (23 de mayo). Esta ley declaraba a Inglaterra como Imperio ("this realme of Englande is an Impire") y ponía las bases jurídicas para el rompimiento con Roma ${ }^{86}$.

La ruptura definitiva y total se produciría en el espacio de tiempo que va desde el 15 de enero al 31 de marzo de 1534, con la obtención del Parlamento de la aprobación de una serie de actos legislativos. Las leyes dictadas fueron las siguientes: Ley sobre la herejía, que prohibió a los obispos iniciar casos de este tipo y entre ellos ya no se incluyó manifestarse contra el papa o su poder; Ley de sumisión del clero y restricción de los recursos, por la cual la "Court of Chancery" se convirtió en el tribunal supremo de apelación en materias eclesiásticas; Ley de nombramientos eclesiásticos y supresión de los anatas, por la que los obispos pasaron a ser nombrados por el rey y se suprimieron definitivamente los anatas para el papa; Ley que suprime el Óbolo de San Pedro, por la cual se terminó con los últimos pagos que se hacían a Roma y que contenía un agregado que pasó en su momento desapercibido pero que tendría gran importancia para las acciones futuras de la revolución: el rey adquiría el derecho de visitar y de reformar los

${ }^{84}$ Según GuY, John, A Daughter's Love. Tomás More \& his Dearest Meg (Boston/New York, 2009), p. 226, la frase es una cita de las Chronicle de Salimbene de Adam, un franciscano del siglo XIII (1221- c. 1290) que criticó a Federico II en su contienda con el papa Inocencio IV.

${ }^{85}$ Aunque todos habían confesado y arrepentido públicamente, se les aplicó la horrenda sentencia de ser colgados, destripados y descuartizados, poniendo sus cabezas en picotas en varias puertas del Puente de Londres. Sólo Richard Master, por razones desconocidas, no fue ejecutado. Cfr. Bernard, G., cit. (n. 49), p. 98.

${ }^{86}$ SChWARZ, A., cit. (n. 27), No 85, p. 146. 
monasterios y casas religiosas; Ley de dispensas, por la cual se dispuso que las dispensas matrimoniales serían de exclusiva competencia del arzobispo de Canterbury, condicionadas a la aprobación real ${ }^{87}$.

Roma tampoco permaneció inactiva. Clemente VII, tras haber censurado el matrimonio de Enrique con Ana, haberle amenazado y finalmente condenado con la pena de excomunión ${ }^{88}$, se decidió finalmente a dictar sentencia en la causa que le había sometido Catalina de Aragón casi siete años antes. En Consistorio de 23 de marzo de 1534 declaró plenamente válido el matrimonio entre Enrique VIII y Catalina ${ }^{89}$.

La culminación del proceso de separación de la Iglesia inglesa de la Católicaromana, se produce el 30 de marzo de 1534, fecha en la que el Parlamento aprobó la Ley de sucesion: Act for the establishment of the King's Succession, cuyo texto resume el origen, la extensión y la intensidad de la transformación religiosa y política de Inglaterra. La ley contiene seis partes, una sola de las cuales se refiere la problema de la sucesión. En estricto rigor, para que los hijos de Ana Bolena, ahora considerada la mujer legítima del rey, heredaran el trono no hacía falta dictar una nueva ley, ya que era perfectamente aplicable la ley aprobada por el Parlamento tres meses después de la batalla de Bosworth por la que ascendió al trono Enrique VII en noviembre de 1485, y que declaraba sucesores de la corona a los herederos de Enrique "of his body lawfully comen perpetually" ("venidos legítimamente de su cuerpo perpetuamente").

No obstante, toda la polémica de la nulidad del primer matrimonio del rey y el nacimiento de una niña y no del esperado heredero varón engendrado en Ana Bolena, llevaron a resumir en una ley todo el nuevo poder asumido por el rey.

La nueva ley fue aprobada a fines de marzo de 1534 del Parlamento poco antes de que ése levantara su sesión ${ }^{90}$. Su texto contiene al menos seis partes bien determinadas.

En el preámbulo se explaya el texto sobre la necesidad de regular la sucesión real ante las ambigüedades y dudas que podrían surgir dado que "el Obispo de Roma”, contrariando el poder que Dios da directamente a los emperadores, reyes

${ }^{87}$ Se conserva una recopilación de todas estas leyes, incluida la que se refiere al "Atteinder" de Isabel Barton, en un volumen editado en Londres por Tomás Marsh, y que está datado en 1562, aunque es posible que sea posterior (1575?). Cfr. SchWARZ, A., cit. (n. 27), No 95, pp. $155-156$.

${ }^{88}$ El papa Clemente VII condenó el matrimonio del rey con Ana Bolena y excomulgó a Enrique pero suspendiendo su ejecución a la espera de una retractación, el 9 de julio de 1533. No habiéndose retractado el rey, el papa aplicó la excomunión (7 de septiembre de 1533). La excomunión se proclamó en los Países Bajos, el lugar más cercano a Inglaterra en noviembre de 1533 .

${ }^{89}$ Además, la sentencia del papa condenaba a Enrique VIII, como parte vencida, a pagar las costas de la causa: cfr. Marc'Hadour, G., cit. (n. 26), p. 490.

${ }^{90}$ La nueva ley (25 Henry VIII, c. 22) fue votada favorablemente y firmada incluso por los parientes de Moro que eran sus parlamentarios: cfr. MARC'HADOur, G., cit. (n. 26), p. 490. Al menos cinco parientes de Moro formaban parte de la Cámara de los Comunes: su cuñado John Rastell, sus tres yernos William Roper, Giles Heron y William Daunce y el marido de su hijastra, Giles Alington: cfr. Reynolds, E., cit. (n. 16), p. 129. 
y príncipes en tiempos pasados ha presumido de tener derecho a intervenir en el nombramiento y reconocimiento de los herederos reales. Se trataba nada más que de una excusa, ya que si bien el papa reclamaba el derecho a liberar de su obediencia a los súbditos de príncipes cristianos que se convirtieran en tiranos, en el siglo XVI esto ya no era operativo ${ }^{91}$, como lo muestra el mismo caso de Enrique VIII.

La segunda parte del Acta relata la cuestión del matrimonio de Enrique y Catalina y repite los argumentos por los cuales Enrique sostuvo su nulidad: que ante la ley de Dios, sin que proceda ni haya sido eficaz ninguna licencia o dispensa, el casarse con la mujer de su hermano Arturo, y haber este conocido carnalmente a aquella, era plenamente nulo, y que así lo había declarado el ahora arzobispo de Canterbury y primado del rey. A ello se agregaba la declaración del mismo Congreso: el matrimonio "debe ser, por la autoridad del presente Parlamento, definitiva, clara y absolutamente declarado, considerado y juzgado como contrario a las leyes del Dios Todopoderoso, y así aceptado, reputado y considerado como de ningún valor ni efecto, sino totalmente nulo y anulado, y la separación consiguiente, hecha por el mencionado arzobispo, debe ser buena y eficaz para todos los intentos y propósitos [...]"92. Como consecuencia, el acta decía que "Lady Catherine" en adelante debía ser llamada y reputada sólo la viuda del príncipe Arturo y no la reina de Inglaterra, así como legítimo, verdadero, sincero y perfecto, el matrimonio celebrado entre el rey y "su más querida y enteramente amada mujer reina Ana”.

La tercera parte del Acta toca la legislación matrimonial y dispone que los matrimonios que son prohibidos por las leyes de Dios no pueden ser validados por dispensa de ninguna autoridad humana, cualquiera sea su estado, grado o condición. La nulidad de estos enlaces puede ser pronunciada por los arzobispos, obispos y otros ministros pero siempre que sean de la Iglesia de Inglaterra.

En cuarto lugar, la ley se abocaba al propósito que anunciaba su título. Declaraba que a la muerte de Enrique la corona pasaría al hijo mayor y, a falta de hijos varones, a la princesa Isabel.

La quinta parte era de carácter penal y amenazaba con penas de alta traición a quienes se opusieran a lo dispuesto por la ley. Se castigaba a todos los que maliciosamente procuraran o hicieran algo para atentar contra el rey o para perjudicar, difamar, perturbar o derogar el legítimo matrimonio entre el rey y la reina Ana, o los herederos de la corona. Pero se distinguía entre los que cometieran el delito escribiendo o imprimiendo o por cualquier acto exterior o escritura, que eran penados con la muerte y la confiscación de bienes, y aquellos que incurrían en él pero por palabras (sin escrito o acto exterior o escritura), siempre que hablaran "maliciously and obstinately". Estos últimos serían castigados con pena de "imprisonment of their bodies at the king's will' (prision corporal durante el tiempo que el rey quisiera) y confiscación de todos los bienes.

La última y sexta parte de la ley contenía algo que ya antes Tomás Moro pudo

${ }^{91}$ Cfr. Reynolds, E., cit. (n. 16), p. 35.
${ }^{92}$ Cfr. Reynolds, E., cit. (n. 16), p. 36. 
presentir como lo peor del despotismo legalista: la obligación de jurar asentimiento al contenido del texto normativo. Cuando Moro supo la anulación del matrimonio con Catalina y la declaración de validez del contraído con Ana Bolena, dijo a su yerno William Roper: "Quiera Dios, hijo, que estos asuntos no tengan que ser confirmados con juramentos" ${ }^{33}$. Debe advertirse que en esos tiempos en que, a pesar de la disensiones religiosas, había certeza de la existencia de Dios y de la vida eterna, sea para la felicidad o para la pérdida del alma, el pecado de perjurio: poner por testigo a Dios de algo falso, era considerado algo gravísimo, una ofensa mortal que merecía por sí misma la condenación de la persona.

La ley ordenaba que tanto los nobles como cualquier súbdito ${ }^{94}$, existente en la actualidad o que llegara a existir, debía prestar "a corporal oath" (juramento corporal: es decir, ante un objeto sagrado como un ejemplar de los Evangelios) en la presencia del rey o sus herederos, o los que ellos deleguen, que observarán, mantendrán, y defenderán "the whole effects and contents of this present Act" ("todos los efectos y contenidos de la presente ley”). Proseguía la ley señalando que todo el que "obstinately refuse" (obstinadamente se niegue) a prestar el juramento cuando le fuere requerido se haría culpable de "misprision of high treason", penada con prisión de por vida y pérdida de sus bienes.

Inmediatamente después de su aprobación, los miembros de las dos Cámaras del Parlamento prestaron juramento. No hay constancia de que alguno, incluidos los obispos, lo hayan rechazado. Sólo el obispo John Fisher no juró ya que se encontraba enfermo en Rochester, y por ello sería citado al Palacio de Lambeth ante la Comisión de autoridades constituida para exigir el juramento.

Moro era laico y ya no integraba el Parlamento, pero se trataba de una personalidad en el reino y fue también citado a comparecer el mismo día del 13 de abril $^{95}$. Siguiendo su costumbre para cada vez que debía enfrentar un asunto o responsabilidad de envergadura, por la mañana fue a la iglesia, se confesó, oyó Misa y comulgó y, sin dejar que su familia le acompañara hasta la barca, se embarcó por el Támesis hacia el Palacio de Lambeth junto con su yerno William Roper. Este declara que lo vio callado, pensativo y triste durante el viaje, hasta que en un momento sorpresivamente sintió que le susurraba al oído: "Hijo Roper, doy gracias a Dios pues la batalla está ganada ['the field is won']"; su confidente no comprendiendo en ese momento a qué se refería sólo atinó a responder "sir Tomás mucho me alegro de ello" 96 .

${ }^{93}$ Roper, W., cit. (n. 12), p. 45.

${ }^{94}$ En esto la ley constituía una innovación. Anteriormente se exigían juramentos de lealtad pero sólo a ciertas personas que asumían cargos o responsabilidades públicas. Cfr. REYNOLDS, E., cit. (n. 16), p. 44.

${ }^{95}$ La citación le fue hecha el día anterior, domingo de Quasimodo, 12 de abril, mientras se encontraba visitando al matrimonio de John Clement y Margaret Giggs en su casa de Bucklersbury, y después de haber asistido a Misa en la Iglesia de Saint Paul. Una vez notificado, volvió a su casa en Chelsea, donde pasó la noche con su familia. Es curioso que la citación a prestar juramento de Moro, Fisher y otras personalidades del reino se adelantara a la fecha de promulgación solemne y general para todo el reino de la Ley de Sucesión lo que ocurrió sólo el $1^{\circ}$ de mayo de 1534.

${ }^{96}$ Roper, W., cit. (n. 12), p. 57. Debe tenerse en cuenta que Roper había ya prestado el 
Lo recibió una Comisión especial compuesta Tomás Cranmer, arzobispo de Canterbury; Tomás Audley, lord canciller; Tomás Howard, duque de Norfolk, y Charles Brandon, duque de Suffolk. La Comisión le pidió que prestara juramento al texto que se había preparado como juramento de adhesión a la ley. Moro pidió tiempo para leer detenidamente tanto la ley de sucesión como el texto del juramento. Después de la lectura, se negó a prestar el juramento de acuerdo a dicho texto y alegó que éste no coincidía con el contenido de la ley ${ }^{97}$. Ante la insistencia de los comisionados, ofreció jurar sobre la legitimidad de la sucesión, pero no sobre el resto del contenido de la ley. Los comisionados, sin saber qué hacer, lo hicieron esperar en el jardín de fuera, donde pudo contemplar cómo otros eran citados y prestaban el juramento. Finalmente, fue puesto bajo la custodia de William Benson, el Abad de Westminster, que le llevó a la Abadía donde estuvo por cuatro días.

Entre tanto, Cranmer, de regreso a su casa de campo en Croydon, escribió una nota a Cromwell, sugiriendo que a Moro y Fischer, excepcionalmente, se les permitiera jurar sólo por la sucesión dinástica (17 de abril de 1534) ${ }^{98}$. Cromwell consultó la sugerencia con el rey pero éste rechazó absolutamente el compromiso, sosteniendo que si se condescendiera con el juramento parcial ello sería ocasión para que todos rehusaran jurar el texto completo e implicaría la destrucción de la entera causa y de todas leyes hechas para su consecución, ya que la omisión del resto del juramento podría entenderse como una confirmación, no sólo de la autoridad del papa, sino como una reprobación del segundo matrimonio del rey ${ }^{99}$.

Ante la renovada exigencia y la negativa de Moro, éste fue oficialmente

juramento como miembro del Parlamento que era. Sólo mucho después cuando puso sus recuerdos por escrito declara comprender que "era porque el amor que tenía a Dios se había forjado en él de manera tan efectiva que había conquistado por entero sus sentimientos más carnales" (pp. 57-58).

${ }^{97}$ En efecto, el documento del juramento contenía algunas diferencias con el texto de la ley: por ejemplo, decía que no se prestaría obediencia a "ninguna Autoridad, Príncipe o Potestad extranjera” (que obviamente hacía alusión al papa) y extendía la adhesión no sólo a la Ley de Sucesión sino a "todas las otras leyes o estatutos hechos desde el inicio del presente Parlamento para la confirmación y debida ejecución de la misma”. Por ello, como señala AKROYD, P., cit. (n. 24), p. 516, "si Moro hubiese prestado el juramento redactado en los términos que le presentó, habría prestado su conformidad a la supresión forzosa de la jurisdicción papal y al cisma real de la Iglesia en Inglaterra. Ello era algo que Moro no podía hacer, aunque le costase la vida”. Según Reynolds, E., cit. (n. 16), p. 43, es probable que Moro tampoco hubiera estado dispuesto a jurar por el entero contenido de la ley, ya que ella negaba también, de un modo implícito, la autoridad del papa y de la Iglesia universal.

${ }^{98}$ MaCCulloch, Diarmaid, Thomas Cranmer (New Haven y London), 1996, p. 124, sostiene que Cranmer estaba inclinado a aceptar un compromiso y permitir que Moro y Fisher juraran sólo sobre el texto principal de la ley y no sobre el preámbulo explicatorio en el que se condenaba la autoridad del papa y el primer matrimonio del rey. Mucho más tarde, el arzobispo declararía que él se había opuesto a la ejecución de Tomás Moro y, según MacCulloch (p. 137), no hay razones para dudar de su afirmación.

${ }^{99}$ El rechazo del rey a que Moro jurara sólo la sucesión consta en carta de Cromwell a Cranmer. Roper, W., cit. (n. 12), p. 58, sostiene que Enrique VIII estuvo inclinado a permitirlo pero que la reina Ana con su insistencia lo exasperó en contra de Moro de tal modo que ordenó que se le exigiera el juramento completo. 
arrestado y conducido a la Torre de Londres, donde lo recibió el lugarteniente (lieutenant) de la prisión, sir Edmund Walsingham ${ }^{100}$.

$\mathrm{Al}$ parecer el alegato de Moro de falta de coincidencia entre el texto del juramento y el contenido de la ley de sucesión, tuvo impacto, ya que en noviembre de 1534 el Parlamento aprobó una nueva ley de sucesión por la que se ratificaba la anterior y se incluía ahora en el mismo texto el juramento que debía prestarse con los añadidos que echara en falta en el anterior. Además, se atribuía al rey el poder de absolver a sus súbditos de otros juramentos, un nuevo poder usurpado al papa ${ }^{101}$.

Varios intentos para que Moro jurara o bien explicara las razones de su negativa no tuvieron éxito. Los interrogatorios sirvieron, sin embargo, para preparar la acusación formal que permitiría iniciar el juicio.

Como buen abogado, en protección de su familia, Moro, un día antes de que la Ley de Sucesión entrara en vigor, constituyó sus propiedades en un trust, nombrando a John Clement, William Rastell y John Watson, su administrador, entre sus trustees. En caso de muerte, los bienes deberían ser distribuidos conforme a las instrucciones depositadas bajo la custodia de John Harris, el secretario privado de Moro. Al parecer, su principal preocupación era su hija Margaret, respecto de la cual Moro no había aún entregado la dote que correspondía a su marido William Roper ${ }^{102}$. Quizás considerando que el trust no podría sostenerse ante los decretos reales, dos días después Moro firmó una escritura por la cual excluía del trust y transfería directamente a Roper dos y medio acres de una finca conocida como Butts Close, compuesta por una casa, establo y jardín y ubicada muy cerca de la casa principal de Chelsea ${ }^{103}$.

\footnotetext{
${ }^{100}$ Aunque la jurisdicción de la Torre estaba en manos del Constable of the Tower, en esta época Sir William Kingston, el "liuetenant" era el goberandor residente de la institución encargado de custodiar la persona de los prisioneros y supervisar la tortura.

${ }^{101}$ Cfr. ReYnOLDS, E., cit. (n. 16), pp. 49-50. La ley se titulaba "An Act ratifying the oath every of the king's subjects hath taken or shall hereafter be bound to take for due observance of the Act made for the surety of the Succession of the King's Highness in the Crown of the Realm", y fue aprobada en la sesión de Noviembre-Diciembre de 1534 del Parlamento (26 Henry VIII, c. 2).

${ }^{102}$ GuY, J., cit. (n. 84), p. 227. Agrega que la operación efectuada por Moro era técnicamente legal, pero semejante a la del deudor que pone a resguardo sus bienes frente a demandas por insolvencia.

${ }^{103}$ Las dos operaciones son mencionadas por Roper, W., cit. (n. 12), pp. 61-62. El primer trust está documentado y se conserva en la Biblioteca Bodleiana de la Universidad de Oxford (MS Ch.Middlesex.a.2, fo. 35) y es comentado por Guy, J., cit. (n. 84), p. 318, quien no ve la ilegalidad que sugiere Derret, J. D. M., More's Conveyance of his Lands and the Law of 'Fraud', en Moreana, 5 (1965), pp. 19-26 (este último especula sólo sobre el relato de Roper y no tuvo a la vista el documento original).
} 


\section{La Ley de supremacía y el Bill of Atteinder de Moro: "I do nobody HARM, I SAY NONE HARM, I THINK NONE HARM [...] IF NOT ENOUGH TO KEEP A MAN ALIVE I LONG NOT TO LIVE"}

En noviembre de 1534, una vez más el Parlamento reunido (en su $7^{\text {a }}$ sesión) tuvo que enfrentar las peticiones de aprobar leyes aún más absolutistas que las que ya se habían promulgado. Junto con la que confirma la sucesión e inserta el texto de un juramento ampliado, el rey quiso que una ley dejara constancia de su nueva calidad de cabeza suprema en la tierra de la Iglesia de Inglaterra. A este nuevo texto legal, aprobado por el Parlamento el 3 de noviembre, se le llamó Ley de Supremacía: Act of Supremacy ${ }^{104}$. El texto de la ley declaraba que "el rey nuestro soberano señor, sus herederos y sucesores, reyes de este reino, deben ser considerados, aceptados y reputados la única cabeza suprema en la tierra de la Iglesia de Inglaterra, llamada Anglicana Ecclesia, y debe tener y gozar, anexadas y unidas a la corona imperial de este reino, tanto los títulos y estilo, como todos los honores, dignidades, preeminencias, jurisdicciones, autoridades, inmunidades, provechos y comodidades que la dicha dignidad de suprema cabeza de la misma Iglesia le pertenecían o le pertenezcan”.

La ley era simplemente declarativa. No añadió ningún delito ni tampoco ningún juramento. Para su ejecución se destinaba un segundo texto legal: una nueva ley que tipificaba el delito de alta traición. Hasta ese entonces el delito estaba descrito y sancionado por una ley de Eduardo III, de 1352, que se consideró como insuficiente para contener todas las formas posibles de oposición al ahora rey, cabeza suprema de la Iglesia ${ }^{105}$.

La nueva Ley de traiciones: Act of Treasons ${ }^{106}$, penalizaba como alta traición a todo aquel que, desde el $1^{\circ}$ de febrero de 1535, "maliciously" anhele, quiera o desee, por palabras o por escrito, realizar o intentar algún daño corporal a la persona del rey o de la reina, o sus herederos, o los prive de ellos o de alguno de sus dignidades, títulos o nombre de sus estados reales o difamatoria y maliciosamente publicite o pronuncie, en forma expresa, por palabras o por escrito, que el rey es herético, cismático, tirano, infiel o usurpador de la corona. A los que se hallare culpable de alta traición se les somete a la pena de muerte y otras penas como se acostumbra para este tipo de delitos.

La intención de la nueva ley era ampliar el tipo penal de la traición para incluir incluso las palabras dichas en contra del soberano aunque no implicaran la intención de hacer algo efectivo en contra del rey. Los Comunes intentaron

${ }^{104}$ El título completo de la ley era: An Act concerning the King's Highness to be Supreme Head of the Church of England and to Have Authority to Reform and Redress All Erros, Heresies and Abuses in the Same (26 Henry VIII, c. 1).

${ }^{105}$ ReYNOLDS, E., cit. (n. 16), p. 59, conjetura que la declaración de no culpabilidad de lord William Dacre por un jurado de pares en julio de 1534, a pesar de ser acusado por el rey como culpable de Alta Traición, pudo haber llevado a la idea de completar la ley para evitar que casos como ese se repitieran. 13.

${ }^{106}$ La ley fue aprobada en el período noviembre-diciembre de 1534: 26 Henry VIII, c. 
restringir la exagerada amplitud que podía tener la legislación por medio de la inclusión del adverbio "maliciosamente"107.

Hasta entonces Moro permanecía en la Torre por una especie de arresto preventivo pero que no estaba respaldado por ninguna condena penal y por tanto podía ser considerado ilegal ${ }^{108}$. Si se le hubiera querido juzgar por oponerse a jurar el Acta de Sucesión debería habérsele acusado ante el supremo tribunal real: "King's Bench Court", pero de acuerdo a esa ley se le habría impuesto como máximo la pena de cadena perpetua y confiscación de bienes. Podría habérsele acusado bajo la nueva Ley de traiciones pero esta sólo se aplicaba desde el $1^{\circ} \mathrm{de}$ febrero de 1535 y había que probar que por palabras o por escrito, maliciosamente, hubiera intentado privar al rey de su título de cabeza suprema de la Iglesia. En ambos casos, se corría el riesgo de que el hábil abogado que era Moro impidiera la condena, dada su estrategia de simplemente negarse a jurar la Ley de sucesión sin expresar las razones que le llevaban a rechazar el juramento.

Algo similar podía suceder con el obispo Fisher. El rey y su secretario Cromwell necesitaban vencer la resistencia de estas dos personalidades sin darles oportunidades de exponer su defensa ante jueces imparciales. Para ello recurrieron al expediente de que fuera el Parlamento el que los declarara imputables mediante leyes especiales de proscripción: los Bills of Attainder ${ }^{109}$. En primer lugar, se consiguió la aprobación de la Ley de Attainder contra Fischer y otros, y luego una ley especial de Attainder contra Tomás Moro ${ }^{110}$. A Fisher y Moro, se les consideró legalmente culpables de actuar deslealmente al rechazar el juramento de la sucesión desde el $1^{\circ}$ de mayo de 1534 . A Moro particularmente se le imputaba haber actuado ingratamente contra el rey, su benefactor ${ }^{111}$.

Por medio de estas leyes, Fisher y Moro fueron condenados a cadena perpetua y privados de todos sus bienes.

La inminencia de pasar a la pena de muerte, por medio de la Ley de Alta Traición, era clara. Los dos prisioneros comenzaron a ser interrogados frecuentemente para que pronunciaran derechamente palabras que los incriminaran frente a la nueva ley.

Tomás Moro fue interrogado oficialmente por Cromwell y otros miembros del Consejo real varias veces entre abril y junio de $1535^{112}$. En carta a su hija Margaret del 2 (o 3) de mayo de 1535, Moro narra el primero de estos interrogatorios y

${ }^{107}$ Cfr. Vásquez de Prada, A., cit. (n. 20), p. 338.

${ }^{108}$ Berglar, P., cit. (n. 21), p. 335, sostiene que la prisión de Moro era ilegal pero que Enrique, bajo la influencia de Cromwell y del clan de los Bolena, ya no se preocupaba de formalidades jurídicas. Según GuY, J., cit. (n. 25), p. 169, Moro fue arrestado pero no inmediatamente juzgado o proscrito por un Bill of Attainder (como se hará más tarde) porque el objetivo del rey era persuadirlo para que cambiara de opinión. De allí que se le concedieran ciertas libertades o privilegios como enviar cartas o recibir visitas.

${ }^{109}$ Sobre este tipo de leyes véase nota 67.

${ }^{110}$ Ambas leyes fueron aprobadas en la $7^{a}$ sesión del Parlamento, entre noviembre y diciembre de 1534. La de Fischer y otros consta en 26 Henry VIII, c. 22; la de Moro en 26 Henry VIII, c. 23. Cfr. ReYNOlds, E., cit. (n. 16), p. 62.

${ }^{111}$ Cfr. Reynolds, E., cit. (n. 16), p. 62.

${ }^{112}$ No hay total seguridad sobre las veces y fechas de los interrogatorios. Al parecer, ellos 
reproduce una de sus contestaciones a quienes por todos los medios pretendían sacarlo de su silencio sobre las nuevas leyes: "Le dije [a Cromwell] en conclusión: 'Soy un fiel y verdadero súbdito del rey, y a diario rezo por él y por todos los suyos y por todo su reino. A nadie hago nada malo, de nadie digo nada malo, de nadie pienso nada malo, sino que para todos deseo bien. Y si esto no es suficiente para mantener a un hombre en vida, la verdad, no deseo vivir más ("I do nobody harm, I say none harm, I think none harm, but wish every body good. And if not enough to keep a man alive, in good faith I long not to live") ${ }^{113}$.

Examinados exhaustivamente sus dichos y, sobre todo, la conversación no oficial sostenida entre Moro y Richard Rich el día 12 de junio, se estimó que las cosas estaban maduras para llevar a Moro al especial juicio que se permitía contra los inculpados del delito de traición ${ }^{114}$.

\section{MORO A JUICIO: “INDIGNATIO PRINCIPES MORS EST"}

\section{La acusación y la preparación del proceso.}

Poco antes de su prisión, el duque de Norfolk había prevenido a Moro de no suscitar el enojo del rey, haciendo alusión a la máxima bíblica: indignatio principes mors est (la ira del príncipe es la muerte ${ }^{115}$ ). Moro lo sabía, pero la muerte no lo atemorizaba al punto de traicionar su conciencia. Le contestó con tranquilidad al que luego sería parte de la comisión judicial que lo condenaría a muerte por traición: “¿Eso es todo, mi lord? [...]. Entonces, en verdad, la única diferencia entre vos y yo es que yo moriré hoy y vos mañana" ${ }^{116}$.

El "hoy" de Moro se acercaba. Ya lo había entrevisto cuando le confiscaron los libros y los materiales de escritura. Ante ello cerró las contraventanas de la celda y la dejó a oscuras. Al preguntarle el guardia la razón de su conducta, contestó: "Como los materiales y los utensilios se han ido, no cabe sino cerrar el negocio ("Now that the goods and the implements are taken away, the shop must be closed") $)^{117}$.

fueron el 30 de abril, el 7 de mayo, el 3 de junio y el 14 de junio de 1535: cfr. Marc'Hadour, G., cit. (n. 26), pp. 505-506; Berglar, P., cit. (n. 21), p. 410; GuY, J., cit. (n. 25), p. 232.

${ }^{113}$ El texto de la carta en latín y su traducción la tomamos de SARDARO, A., cit. (n. 11), pp. $275-276$.

${ }^{114}$ Enrique VIII podría haber acusado a Moro ante el Parlamento mediante un nuevo Bill of Attainder pero ahora por alta traición con pena de muerte, pero no lo hizo. Puede haber influido en que en esta época el Parlamento no estaba en sesión, pero lo más seguro es que el proceso ante el Parlamento podría ser considerado menos susceptible de manipular como un tribunal integrado por personas nombradas ad hoc por el mismo gobierno.

${ }^{115}$ El origen de la máxima está en el versículo del libro de los Proverbios que la Vulgata traduce así: "Indignatio regis nuntii mortis, et vir sapiens placabit eam" (Prov. 16, 14). En castellano, la traducción es "la ira del rey es mensajera de muerte; pero el hombre sabio lo apacigua".

${ }^{116}$ Roper, W., cit. (n. 12), p. 56. El papa Pío XI, en su Carta Decretal Saevis Agitata de 19 de mayo de 1535, recoge expresamente este episodio para ilustrar la santidad de Moro: cfr. A.A.S.,. XXVIII (1936), n. 6, pp. 185-204.

${ }^{117}$ StApleton, T., cit. (n. 14), p. 140. En el momento en que se llevaron sus materiales de escritura (pluma, papel, tinta), Moro se encontraba escribiendo un comentario a la Pasión del Señor, que quedó inconcluso. Justamente la interrupción se produjo cuando había lle- 
El 28 de junio de 1535, un Gran Jurado en Westminster emitió una citación para llevar a juicio por traición a Tomás Moro. El juicio se celebraría el jueves siguiente a la fiesta de San Juan Bautista, esto es, el 1 de julio. Moro había permanecido ya 14 meses en prisión ${ }^{118}$.

La acusación, el “indictment”, había sido ya cuidadosamente preparada, probablemente por Cromwell sobre la base de declaraciones de testigos, especialmente la de Richard Rich. Era un documento de unas dos mil palabras redactado en latín, salvo algunas frases que se reproducían en inglés.

La Corona acusaba a Tomás Moro, conforme a la Ley de Traiciones, de privar al rey de sus títulos, en especial del título y nombre de Suprema Cabeza en la Tierra de la Iglesia de Inglaterra. Se concluía que los "juratores" (jurados) declaraban que "Tomás Moro, falsa, traidora y maliciosamente, por artimañas imaginó, inventó, practicó e intentó, privar a nuestro soberano señor el rey de su dignidad, título y nombre establecidos en los estatutos mencionados, particularmente, de su dignidad, título y nombre de cabeza suprema en la Tierra de la Iglesia de Inglaterra, en manifiesto desprecio del rey y en derogación de su corona real, contra la forma y los efectos de los dichos estatutos, y contra la paz de nuestro señor el rey"119.

Los cargos de la acusación pueden sistematizarse en cuatro alegaciones:

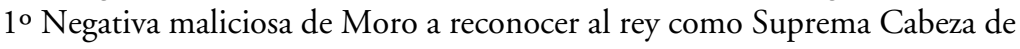
la Iglesia de Inglaterra.

$2^{\circ}$ Conspiración con John Fisher declarado y condenado por traición.

$3^{\circ}$ Descripción de la Ley como una espada de doble filo, coincidiendo en esta expresión con las respuestas de Fisher.

$4^{\circ}$ Declaración de que el Parlamento no debe ser obedecido si declara al rey

gado al texto del Evangelio que dice: "Et iniecerunt manus in Jesum" ("y pusieron las manos sobre Jesús": cfr. Jn. 18,12]. El texto logró ser conservado y ha sido traducido al castellano por Álvaro de Silva: Moro, Tomás, La agonía de Cristo (trad. castellana, $3^{a}$ edic., Madrid, 1989). En su introducción, Silva señala que se observa que Moro escribía claro pero de prisa, sabiendo que le quedaba poco tiempo: "El crescendo del último párrafo es un buen ejemplo. Si su proximidad a la muerte explica de alguna manera la rapidez en la escritura, la claridad y cuidado de la misma caligrafía (perfectamente legible hasta en las correcciones del texto) muestran con detalles materiales la serenidad de su ánimo en aquellos momentos finales": cfr. SiLva, Álvaro de, Introducción a Moro, Tomás, La agonía de Cristo (trad. castellana, $3^{\mathrm{a}}$ edic., Madrid, 1989), p. X.

${ }^{118}$ Según informa Bellamy, J., cit. (n. 18), p. 94, el tiempo en que un prisionero sospechoso de traición podía permanecer en prisión antes de ser juzgado variaba enormemente en la época: podía ser de pocos días a una década. Cuando el prisionero era importante social o políticamente el período era usualmente largo. Pone como ejemplo el caso de Moro, si bien menciona que desde fines de 1534 Moro estaba privado de libertad por una Act of attainder que le imputaba una ofensa menor que la traición.

${ }^{119}$ El texto de la conclusión del "indictment" reza como sigue: "Sicque Juratores predicti dicunt, quod praefatus Thomas More false, proditorie, et maliciose, arte imaginavit, inventavit, practicavit, et attemptavit praefatum serenissimun dominum nostrum Regem de dictis dignitate, titulo, et nomine supradicti status sui Regalis, videlicet, de dignitate titulo, et nomine suis supremi capitis in terra Anglicanae ecclesie penitus deprivare, In ipsius domini Regis contemptum manifestum, et corone sue regie derogacionem, contra formam et effectum statutorum praedictorum, Et contra pacem eiusdem domini Regis": cfr. Sir Thomas More's Indictment, cit. (n. 9), p. 276. 
Suprema Cabeza de la Iglesia en una respuesta dada a Richard Rich, el día 12 de junio ${ }^{120}$.

La acusación en el fondo pasaba de imputar como maliciosa la resistencia a declarar que el rey era suprema cabeza de la Iglesia (silencio malicioso), a la realización de actos para conspirar y ayudar a otros a resistirse (complot con Fisher), hasta terminar alegando la negación con palabras del nuevo título del rey (conversación con Rich).

De acuerdo al procedimiento, el documento de la acusación no era proporcionado al reo y éste no lo conocía hasta que era leído en voz alta en la sesión del juicio ante los jueces y el jurado ${ }^{121}$.

\section{Jueces y jurados.}

Los juicios ordinarios contra la Corona eran conocidos por la "King's Bench Court", pero en los casos especiales de alta traición se nombraba una Comisión de "oyer and terminer", que eran seleccionados por el poder real e incluso por el rey en persona ${ }^{122}$, sin que fuera necesario que todos ellos fueran jueces o abogados ni tampoco imparciales respecto del acusado. Pero era usual que se nombraran entre ellos algunos jueces de las Cortes del rey, abogados de la corona e incluso ministros ${ }^{123}$.

La Comisión que fue nombrada para escuchar las audiencias del juicio de Moro estaba presidida por el lord canciller, sir Tomás Audley, e integrada por otras 18 personas, de las cuales seis eran jueces: el duque de Norfolk, Tomás Howard (que era tío de Ana Bolena); el duque de Suffolk, Charles Brandon (que era yerno del rey); el conde de Huntingdon; el conde de Cumberland (lord Privy Seal); el conde de Wiltshire, Tomás Bolena (padre de Ana); lord Montague; lord Rochford, George Bolena (hermano de Ana); lord Windsor; Tomás Cromwell (Secretario del rey); sir John FitzJames ("Chief Justice" del "King's Bench"); sir John Baldwin ("Chief Justice" del "Common Pleas"); sir Richard Lister ("Chief Baron of Exchequer”); sir William Paulet; sir John Port; sir John Spelman; sir Walter Luke; sir William FitzWilliam; y sir Anthony FitzHerbert ${ }^{124}$

De estos 19 comisionados, al parecer sólo 15 estuvieron realmente presentes en el juicio del 1 de julio ${ }^{125}$.

\footnotetext{
${ }^{120}$ En realidad la acusación contiene un solo único "charge" pero descompuesto en diversos hechos imputados al acusado, que pueden sistematizarse en cuatro principales acusaciones. En este sentido, Reynolds, E., cit. (n. 16), pp. 66 y ss. Por su parte, Derret, J., cit. (n. 17), p. 59, señala que la acusación refiere ocho actos de traición, pero también los agrupa en los cuatro cargos a los que se refiere Reynolds y que exponemos en el texto principal.

${ }^{121}$ ReYnolds, E., cit. (n. 16), p. 70.

${ }^{122}$ Según Bellamy, J., cit. (n. 18), p. 123, en los casos más importantes de procesos de traición en los cuales el rey estaba interesado, éste mismo elegía cada uno de los miembros de la comisión de oyer and terminer.

${ }^{123}$ Bellamy, J., cit. (n. 18), p. 122.

${ }^{124}$ Reynolds, E., cit. (n. 16), p. 71. La "commission" original aparece en Public Records Office, Baga de Secretis. Pouch 7, Bundle 3, m. 10, según Derret, J., cit. (n. 17), p. 59, n. 27.

${ }^{125}$ Harpsfield, N., cit. (n. 13), p. 183, habla de 15 comisionados, de lo que Reynolds,
} 
Pero los comisionados sólo aplicaban la ley, una vez que el jurado se pronunciaba sobre si el acusado era culpable ("guilty") o inocente ("non guilty"). En el juicio de Moro, hubo doce personas que conformaron este jurado, que se conformó sólo una vez que el acusado se declaró como no culpable del delito de traición. Sus nombres se conservan pero no han sido identificados. Se sabe sí que dos eran caballeros ("knigths"), dos señores ("esquires") y ocho simples hidalgos ("gentlemen") ${ }^{126}$. Dos de ellos habían integrado el jurado que encontró culpable de traición a John Fisher ${ }^{127}$.

Aunque para los estándares actuales puede parecer poco imparcial la composición de la comisión de jueces, e incluso parece que uno de los miembros del jurado había acusado previamente a Moro ${ }^{128}$, para las tradiciones judiciales de la Inglaterra del siglo XVI estaba todo en orden. Según Derret, los antecedentes que se manejan de la conformación de jueces y jurados no permiten dudar de la buena fe del tribunal ${ }^{129}$. No hay constancia de que Moro haya impugnado a alguno de ellos, aunque el procedimiento se lo permitía ${ }^{130}$.

E., cit. (n. 16), p. 74, sugiere que quizás cuatro de los originalmente nominados estuvieron ausentes. Derret, J., cit. (n. 17), p. 59, n. 28, señala que de los jueces sólo estaba ausente Fitz William; de los legos habría estado ausente Lord Montague.

${ }^{126}$ Thomas Stapleton, señala que los doce eran personas del mismo rango que el acusado: "Yo podría dar los nombres y apellidos de cada uno pero, en atención a su infame veredicto, prefiero pasarlos en silencio y esconder la ignominia de sus honradas familias": STAPLETON, T., cit. (n. 14), p. 194. No obstante, los investigadores han descubierto en los archivos donde se encuentra una copia de la acusación de Moro, un papel de pergamino que parece contener los nombres de los miembros del jurado de Moro: es un listado de muchos nombres, pero doce aparecen marcados con la expresión "Jur". Estos son los siguientes: Thomas Palmer, Thomas Spert, Gregorius Lovell, Thomas Burbage, Willielmus Brown, Jasper Leyke, Thomas Byllyngton, Johannes Parnell, Galfridus Chamber, Edwardus Stokwod, Ricardus Bellamy, Georgius Stokys: cfr. Chambers, R. W., Nota a p. 192 de HarPSField, Nicholas, The Life and Death of St. Thomas Moore, Knight, sometymes Lord High Chancellor of England (London, 1932, reimp. 1963), pp. 349-350. La biografía del nieto de Moro, Cresacre, confirma estos nombres aunque con algunas variaciones en su escritura; dice que los miembros del jurado fueron: "Sir Thomas Palmer, sir Thomas Pierte, George Lovell, esquire; Thomas Burbage, esquire; Geoffrey Chamber, gentleman; Edward Stockmore, gentleman; William Browne, gentleman; Jaspar Leake, gentleman; Thomas Billington, gentleman; John Parnel, gentleman; Richard Belamy, gentleman; George Stoakes, gentleman”: cfr. Moro, C., cit. (n. 15), pp. 266-267.

${ }^{127}$ ReYNOLDS, E., cit. (n. 16), p. 118.

${ }^{128}$ Según John Guy es probable que se trate de de John Parnell, el mismo que había intentado sin éxito acusar a Moro de haber aceptado una copa como soborno: cfr. GuY, J., cit. (n. 34), p. 75; GuY, J., cit. (n. 25), p. 189; GuY, J., cit. (n. 84), p. 259. Véase el capítulo IV, párrafo 1 de este trabajo.

${ }^{129}$ Derret, J., cit. (n. 17), p. 60.

${ }^{130}$ Dice Bellamy, J., cit. (n. 18), p. 140, que en esta época el prisionero podía objetar a cada jurado que era llamado a prestar juramento si tenía alguna apropiada razón para hacerlo, hasta un máximo de diez. 


\section{EL INICIO DEL JUICIO. LOS TRES PRIMEROS CARGOS Y SU FRUSTRACIÓN:} "QUI TACET, CONSENTIRE VIDETUR"

El jueves 1 de julio de 1535, Moro fue conducido en barca por el río, desde la Torre de Londres al Palacio de Westminster, lugar donde funcionaba la "King's Bench Court”. El anterior juez ahora iba a ser juzgado. Aunque las galerías superiores eran abiertas a parientes y amigos, no hay constancia de que al proceso haya asistido alguno de los familiares de Moro $^{131}$. No obstante, poco después de la muerte del condenado, comenzaron a circular en Europa varios relatos del proceso que parecen sustentarse en testigos presenciales, los que junto a las primeras biografías, son las principales fuentes de la reconstrucción del histórico juicio ${ }^{132}$.

Debe tenerse en cuenta que, de acuerdo al procedimiento de la época, el reo conocía la acusación sólo en la audiencia y no tenía derecho a abogado defensor ni tampoco a presentar pruebas o testigos en su favor ${ }^{133}$. Moro, por tanto, sólo disponía de sus propias habilidades de abogado y humanista para hacer frente a quienes le acusaban de traidor ${ }^{134}$. Debía defenderse ante la Comisión especial, ya que no existía la figura de un acusador o fiscal (prosecutor) ${ }^{135}$.

Durante la lectura del documento de la acusación (en latín), el acusado permaneció de pie $^{136}$. Finalizada la lectura, el lord canciller Audley, presidente del Tribunal, y el duque de Norfolk trataron de persuadir a Moro que cediera en su posición con la promesa de obtener el perdón del rey ${ }^{137}$. Este ofrecimiento de perdón era un trámite usual en la apertura de este tipo de juicios ${ }^{138}$.

Moro contestó: "Señores míos, agradezco afectuosamente vuestra buena voluntad. Sólo ruego a Dios todopoderoso que quiera mantenerme en esta mi justa opinión, de modo que pueda perseverar en ella hasta la muerte. En cuanto

${ }^{131}$ Reynolds, E., cit. (n. 16), p. 72, señala que puede ser que el mismo Moro lo haya pedido, aunque lo más probable es que su ausencia se deba a una orden del rey.

${ }^{132}$ Véase el capítulo I, notas 4 a 7.

${ }^{133}$ Reynolds, E., cit. (n. 16), p. 70; Derret, J., cit. (n. 17), p. 60. Bellamy, J., cit. (n. 18), p. 142, confirma que en los juicios de traición por regla no era permitido al imputado la asistencia o consejo legal en la sala de la tribunal.

${ }^{134} \mathrm{Ni}$ su yerno William Roper ni su sobrino William Rastell, ambos abogados miembros de la barra, estuvieron presentes en el juicio, quizás por temor a que se les pidiera ayudar a su ilustre pariente: cfr. Derret, J., cit. (n. 17), p. 60.

${ }^{135}$ Bellamy, J., cit. (n. 18), p. 145, señala, sin embargo, que en el tiempo de Enrique VIII el "attorney general" y el "solicitor general" eran los responsables de sostener la persecución tanto fuera como dentro del juicio.

${ }^{136}$ Por la extensión de la acusación, su lectura en latín debió haber tomado casi una hora: cfr. GuY, J., cit. (n. 25), p. 190.

${ }^{137}$ Las relaciones del juicio: Novitates y Ordo señalan que la exhortación la hizo sólo el duque de Norfolk, pero The Paris News Letter cit. (n. 4), p. 258, la atribuye al canciller y al duque. Reynolds, E., cit. (n. 16), pp. 74-75, señala que lo más probable es que ambos hayan hablado separadamente y que las relaciones las condensaron en una sola narración.

${ }^{138}$ Reynolds, E., cit. (n. 16), p. 77; Derret, J., cit. (n. 17), p. 61. Bellamy, J., cit. (n. 18 ), p. 138, sostiene que el ofrecimiento de perdón si el acusado se retractaba al inicio del juicio no era "desconocido" en este tipo de procesos y pone como ejemplo justamente el caso de Tomás Moro. 
a las acusaciones en mi contra, dudo que tenga el entendimiento, la memoria y la palabra que puedan responderlas satisfactoriamente, dada la prolijidad y la gran cantidad de los artículos, y atendida también la larga detención en prisión, la grave enfermedad y debilidades que ahora sufro" ${ }^{139}$. Ante ello, los jueces ordenaron que se trajera una silla y se permitió que Moro se sentara para proceder a la contestación de los $\operatorname{cargos}^{140}$, los que consideró improcedentes y advirtió que si los odiosos términos de "maliciosamente, traicioneramente y diabólicamente" se omitieran de la acusación, no veía nada que con lo que se le pudiera procesar con justicia ${ }^{141}$.

El primer cargo de la acusación decía relación con su resistencia a declarar si aceptaba o no la supremacía del rey como Cabeza de la Iglesia de Inglaterra. El cargo se basaba en las respuestas dada por Tomás Moro al interrogatorio realizado el 7 de mayo de $1535^{142}$. En esa ocasión, ante los comisionados Tomás Cromwell, Tomás Bedyll, John Tregonwell y otros miembros del Consejo del rey, se le pidió que reconociera al rey como cabeza suprema de la Iglesia. Moro no lo hizo y se limitó a declarar: "No me mezclaré con tales materias, porque estoy totalmente determinado a servir a Dios, y a pensar sobre su Pasión y mi tránsito fuera de este mundo".

Frente a ello, el acusado respondió que nunca había pronunciado ninguna palabra contra el matrimonio del rey y si se le imputaba negarse a jurar la Ley de Sucesión, ese supuesto error ya estaba condenado y por él sufría prisión de por vida y había perdido sus bienes. Resulta curioso que el acusado haya traído a cuento la cuestión del matrimonio real, cuando la acusación no lo mencionaba ni le imputaba directamente su oposición a él ${ }^{143}$; es posible que haya querido

${ }^{139}$ Cfr. The Paris News Letter cit. (n. 4), pp. 258-259. Según Pole, R., cit. (n. 8), p. 218, la acusación era especialmente larga e intricada por lo que Moro, a pesar de escucharla atentamente y poseer una memoria superior a la ordinaria, confesó que apenas podía recordar un tercio de las cosas que se decían en su contra. Es probable que la debilidad en la que se encontraba después de tanto tiempo de prisión le jugara en contra, como él alega. Pero, es posible que sea sólo una cierta excusa retórica, porque puede verse que luego Moro se hizo cargo de todos los hechos que se le imputaban en la acusación.

${ }^{140}$ Durante el resto de su alegato parece haber permanecido sentado: cfr. STAPleton, T., cit. (n. 14), p. 191. HARPSFIELD, N., cit. (n. 13), p. 184, añade que antes de que se sentara Moro habló de pie pero apoyado en un bastón.

${ }^{141}$ Roper, W., cit. (n. 12), p. 67.

${ }^{142}$ Sólo la acusación menciona este interrogatorio del 7 de mayo de 1535: cfr. Sir Thomas More's Indictment, cit. (n. 9), p. 270-271. Algunos piensan que se trata de un error de datación y que, en verdad, corresponde al primer interrogatorio que tuvo lugar el 30 de abril, ya que las preguntas y respuestas coinciden con el que Moro relata en carta a su hija Margaret y que él declara haberse realizado "el último día de abril": cfr. carta a Margaret ROPER, 2 o 3 de mayo de 1535 en Moro, T., Cartas cit. (n. 11), p. 86. Si fue así no hay razones que pudieran explicar que los acusadores cambiaran la fecha al 7 de mayo (la ley de traiciones había entrado en vigencia el 1 de febrero); Moro, o no advirtió el error de la fecha o prefirió no invocarla para reclamar la nulidad del cargo. En este sentido, se pronuncia REYNOLDS, E., cit. (n. 16), pp. 85-87. No obstante, según Chambers, R., cit. (n. 19), p. 327, se trata de dos interrogatorios, aunque con coincidencia en los contenidos. Por esta segunda tesis se inclina la cronología de Moro estudiada por Marc'Hadour, G., cit. (n. 26), p. 505.

${ }^{143}$ Por eso se equivoca la biografía de Moro, C., cit. (n. 15), pp. 258 y ss. cuando señala 
recordar al auditorio cuál era la cuestión de fondo de todo el pleito, como lo dirá expresamente después del veredicto de culpabilidad ${ }^{144}$.

Volviendo a la negativa a manifestar una opinión directa sobre la cuestión de la supremacía que era el cargo expreso que se le dirigía en la acusación, adujo que ninguna ley podía castigarle sólo por su taciturnidad y silencio, sin que se adujeran en su contra hechos o palabras.

El abogado del rey ("general attorney"), sir Christopher Hales, retrucó que el silencio mismo era una prueba segura y la demostración de una naturaleza perversa contra la ley, ya que ningún fiel súbdito se negaría a confesar, cuando fuera requerido, que la ley es buena, justa y legítima ${ }^{145}$.

Moro contestó que el silencio no podía ser interpretado como malicia, y que si se aplicaba la regla del Derecho común (romano): qui tacet, consentire videtur ${ }^{146}$, debía llegarse a la conclusión de que su silencio era más una confirmación que una condenación de la ley. No era que Moro quisiera que se entendiera que aprobaba la ley con su silencio sino hacer ver que esta no contenía ningún precepto que dispusiera que el silencio debía estimarse como rechazo y menos como un acto de deslealtad o traición. Su silencio no podría ser interpretado de este modo según el derecho común ${ }^{147}$.

El acusado prosiguió enfrentando el problema de si puede un ciudadano ser obligado a declarar su conformidad con lo dispuesto por una ley. Señala

que el primer cargo contra Moro habría sido oponerse al segundo matrimonio del rey.

${ }^{144}$ ReYNOLDs, E., cit. (n. 16), p. 80, no cree que Moro se haya sencillamente equivocado: "es dificultoso creer que al comienzo del juicio, mientras su mente estaba fresca, Moro, el diestro abogado, haya confundido el primer cargo contra él, a menos que él haya deliberadamente retornado al origen de sus problemas". Añade también que puede ser que haya un cambio de orden de sus exposiciones en el juicio por el observador que lo puso por escrito en París, unos diez días después. Derret, J., cit. (n. 17), p. 62, piensa que, si bien Moro pudo haberse referido a la cuestión del matrimonio es difícil de admitir que lo haya hecho al comienzo del juicio, salvo que haya pretendido alegar que la Corte no tenía jurisdicción por las controversias suscitadas entre él y el resto del Consejo real que ahora integraba el tribunal, incluidos los parientes de Ana Bolena; pero agrega que si lo hizo, el tribunal ha podido rechazar el alegato ya que la acusación no imputaba ninguna ofensa directa a la reina Ana.

${ }^{145}$ Derret, J. Duncan M., More'silence and his Trial, en Moreana 22 (1985) 87-88, pp. 25-27, intenta explicar la configuración del silencio como crimen por parte de los consejeros de Enrique VIII, por medio de una influencia del ius commune o civil law, y concretamente de la ley romana de crimen de lesa majestad aprobada por los emperadores Arcadio y Honorio en el año 297 d.C., que se recoge en el Códex de Justiniano (C. 9.14.3). En la interpretación de Bartolo, los que revelaban una conspiración eran premiados, los que delataban oportunamente a sus cooperadores eran perdonados, mientras que los que mantenían silencio sobre la conspiración eran castigados por la ley.

${ }^{146}$ Moro se refiere a la máxima del Derecho romano y canónico, que era conocido entonces como Derecho común. Por eso, la Paris News Letter habla de "le droict commun"; la Expositio, de "legibus"; las Novitates de "ius commune" y la versión alemana de "in weltlichen Rechten". Cfr. ReYnolds, E., cit. (n. 16), p. 87, n. 2. En cambio, el relato de Reginald Pole pone como fuente de este adagio aducido por Moro la enseñanza de los jurisconsultos: "idque pervulgat [o] jurisperitorum verbo confirmaret, quo dici solet, 'Qui taceat, eum videri consentire', hoc tum minime audiebatur" [POLE, R., cit. (n. 8), p. 220].

${ }^{147}$ Reynolds, E., cit. (n. 16), p. 88. 
que en cosas que se refieren a la conciencia, el buen ciudadano es más obligado a respetar el juicio de su conciencia y de su alma más que cualquier otra cosa en todo el mundo, especialmente cuando su conciencia es de tal suerte que por ella la persona no da ocasión de difamación ni de tumulto ni de sedición contra su príncipe, como era en su caso. Añadió que él incluso no había discutido ni abierto sus razones de conciencia a nadie en absoluto. Nadie podía contradecirlo en esto, porque fue una actitud que él asumió desde un comienzo y ni siquiera a su querida hija Margaret le dio a conocer los motivos para negarse a someterse a las leyes de Sucesión y Supremacía.

Los cargos segundo y tercero están muy conectados, ya que se refieren a una suerte de complicidad con John Fisher, ya condenado como traidor, según el juicio que había tenido lugar el 17 de junio en el mismo lugar (la ejecución se había llevado a efecto por decapitación el 22 de junio de $\left.1535^{148}\right)$. El segundo cargo señalaba que, durante su prisión en la Torre, Moro había enviado varias cartas a Fisher, en las que le animaba a resistir al rey y le daba a conocer que su estrategia era la de no revelar las razones de la oposición al juramento. Le aconsejaba, además, que diera respuestas espontáneas para evitar que expusiera argumentos similares a los de Moro, coincidencia que podría ser aprovechada por sus adversarios para acusarlos de concertación para resistir la autoridad real.

El acusado reconoció el envío de las cartas ${ }^{149}$. Manifestó que deseaba grandemente que ellas pudieran ser leídas en público y que lamentaba que ellas hubieran sido quemadas. Detalló que en alguna de ellas sólo había comunicaciones de carácter familiar y recomendaciones amistosas. En otra, el obispo le mandó preguntar lo que había respondido al primer interrogatorio en la Corte, a lo que contestó que él había declarado según su conciencia y que el debía declarar según la suya. En una tercera, en la que el obispo preguntaba sobre los cargos del alma de Moro, esté contestó que "ninguno había". Concluyó alegando que sobre el contenido de las cartas no podía establecerse fundamento para condenarle a muerte según la ley ${ }^{150}$.

El tercer cargo de la acusación estaba destinado a confirmar la complicidad

${ }^{148}$ Con anterioridad, el día 21 de mayo de 1535, el papa Paulo III había conferido el capelo cardenalicio a John Fisher, junto a otros prelados. Sin duda pretendía otorgarle una mayor protección, pero Enrique VIII se indignó aún más y consideró el nombramiento como una provocación.

${ }^{149}$ Según Stapleton, T., cit. (n. 14), p. 193, Moro reconoció haber enviado ocho cartas a Fisher mientras estuvo en la Torre.

${ }^{150}$ Los hombres de Cromwell habían realizado una insistente pesquisa sobre el contenido de las cartas entre Moro y Fisher en la Torre. El día 8 de junio se interrogó a George Gold, el sirviente del Lugarteniente de la Torre, quien hizo de correo entre ellos; el día 10 de junio se interrogó a John à Word, el sirviente de Moro (que era analfabeto); el día 11 de junio fue el turno de Richard Wilson, el sirviente de Fisher. Finalmente, los días 12 y 14 de junio fueron interrogados al respecto los mismos Fisher y Moro. En todos estos interrogatorios, nada surgió que pudiera comprometer la responsabilidad de los prisioneros por haber complotado en contra del rey. Una revisión de sus testimonios en ReYnOLDs, E., cit. (n. 16), pp. 94-105. Puede verse una manifestación del buen humor de Moro, incluso en estas circunstancias tan penosas, en el testimonio de Wilson de que Moro envió a Fisher como regalo de Año Nuevo de 1535, un papel con la leyenda: "200 libras en oro", junto con una imagen de la Epifanía. 
entre Fisher y Moro por el uso de la misma expresión en contra de la ley: "una espada de dos filos". La acusación decía que el 3 de junio, al ser nuevamente interrogado, Moro se negó "maliciosamente" a responder directamente a la cuestión de la Supremacía y dijo: "La ley y estatuto por el cual el rey es hecho suprema cabeza, es como una espada de dos filos ("a sword with two edges"), por los cuales, si un hombre dice que tales leyes son correctas, entonces peligra su alma, y si dice lo contrario, entonces es la muerte del cuerpo. Por lo tanto, no daré ninguna otra respuesta a la pregunta porque no quiero dar ocasión para acortar mi vida" ${ }^{\text {151 }}$. La acusación hacía ver que el mismo día, al ser interrogado en la Torre, John Fisher "maliciosamente instruido" por Moro, declaró: "No me mezclaré con la materia, pues el estatuto es como una espada de doble filo" ${ }^{152}$.

Moro aclaró que su respuesta había sido condicional, en el sentido de que en caso de que la ley fuera una espada de doble filo, no podía decir cómo debía comportarse un hombre en el mundo y actuar de forma que no cayese en uno u otro de los peligros. Señaló, enseguida, no conocer la respuesta que hubiera dado Fisher y explicó la supuesta coincidencia por la correspondencia y conformidad de los escritos, conocimientos y estudios de ambos, y no en un acuerdo concluido entre ellos para enfrentar a sus interrogadores ${ }^{153}$.

Aunque como veremos estos cargos no prosperaron, hay constancia de que impresionaron a los comisionados ${ }^{154}$.

\section{El CUARTO CARgo. El testimonio De Rich: "I AM SORRIER FOr YOUR PERJURY THAN FOR MY OWN PERIL”}

Hasta este momento se veía difícil sostener la acusación: los cargos, siendo ya débiles en sí mismos, parecían totalmente insuficientes frente a las defensas contundentes del abogado Moro. Este había demostrado que de los tres primeros cargos ningún acto o palabra maliciosa podía serle imputado. De allí que el "attorney general” del rey presentara el caso por la Corona dejando sólo el cuarto cargo en que se le acusaba de haber atentado con palabras contra la supremacía real ${ }^{155}$.

${ }^{151}$ Sir Thomas More's Indictment, cit. (n. 9), p. 274.

${ }^{152}$ Sir Thomas More's Indictment, cit. (n. 9), p. 273.

${ }^{153}$ La metáfora de la espada de dos filos fue usada por Fisher y Moro en sus interrogatorios del día 3 de junio de 1535, pero Moro ya la había empleado en sus respuestas al interrogatorio del día 12 de mayo. Bernard, G., cit. (n. 49), p. 121, sostiene que el uso por ambos de la misma comparación, más que poner en evidencia una conspiración entre los dos prisioneros, da cuenta de que se trataba de una expresión que puede ser considerada un lugar común. Señala que el mismo Fisher la había usado en un sermón muy anterior para describir el efecto del pecado mortal, que como "the two edged sword" por un lado da muerte al cuerpo y por otro al alma y de un solo golpe.

${ }^{154}$ Según el breve relato del juicio encontrado en los informes jurídicos privados de Sir John Spelman, quien fue uno de los integrantes de la Comisión de oyer et teminer, Tomás Moro fue juzgado como traidor además de por haber privado al rey de su título de cabeza de la Iglesia, por haber sido "aider, counsellor and abetor [cómplice, consejero e inductor]" del obispo Fisher: cfr. REYNOLDS, E., cit. (n. 10), p. 29.

${ }^{155}$ Derret, J., cit. (n. 17), p. 63. 
La acusación imputaba a Moro haber rechazado el título del rey de Suprema cabeza de la Iglesia en Inglaterra, en una conversación entre Moro y Richard Rich, el "solicitor general", que tuvo lugar en su celda el día 12 de junio.

$\mathrm{Al}$ parecer el acusado no tuvo más opción que aceptar que el cargo era legalmente sustentable y no podía ser dejado sin efecto como los anteriores sin entrar a juicio. Por ello, Moro frente a él se declaro "Non guilty" y se abrió la fase probatoria ${ }^{156}$.

Richard Rich fue llamado a confirmar la versión contenida en la acusación de las palabras del acusado. Según esta Rich se presentó el 12 de junio de 1535 en la celda de Moro no para interrogarlo, sino para confiscar sus libros, ayudado por algunos auxiliares. Pero incidentalmente buscó la conversación de Moro; le preguntó qué diría si el Parlamento aprobara una ley por la cual se dijera que él mismo, Rich, debía ser considerado rey de Inglaterra. Moro habría contestado que si así fuera se cometería una ofensa por denegar a Rich como rey, pero a ello habría replicado con otro caso hipotético: si el Parlamento aprobara una ley que dijera que Dios no debe ser Dios y que todo el que se oponga a esa ley sería culpable de traición. Rich habría respondido que no debía obedecerse esa ley ya que es imposible que Dios no sea Dios, pero volviendo al primer ejemplo habría preguntado a Moro que, ya que estaba dispuesto a que él (Rich) fuera obedecido como rey si el Parlamento así lo disponía, por qué no aceptaba que el Parlamento declarara al rey como suprema cabeza de la Iglesia. La acusación sostenía que, en ese momento, Tomás Moro “maliciosamente”, persistió en su traición, y respondió que "Los casos no eran equivalentes, ya que el rey puede ser puesto y depuesto por el Parlamento; y todo súbdito estando en el Parlamento puede consentirlo; pero, en lo que se refiere a la supremacía, el súbdito no puede ser obligado, ya que él no puede dar su consentimiento en el Parlamento, pues si se aceptara esto en Inglaterra, en muchos otros países no afirmarían lo mismo" 157 .

No sabemos exactamente lo que declaró Richard Rich en el juicio. En todo caso, es seguro que refrendó con juramento la autenticidad de las palabras de Moro transcritas en la acusación. Para reforzar el testimonio de Rich, se llamó a declarar a dos de los que lo acompañaron en el retiro de los libros del prisionero: sir Richard Southwell y un sirviente de apellido Palmer ${ }^{158}$. Ambos, sin embargo,

${ }^{156}$ Seguimos en este punto a GUY, J., cit. (n. 25), p. 191.

${ }^{157}$ Sir Thomas More's Indictment, cit. (n. 9), p. 275-276: "quod casus illi non erant consimiles, Quia, Rex per parliamentum fieri potest, et per parliamentum deprivari potest, ad quem actum quilibet subditus ad parliamentum existens suum prebeat consensum, Sed, ad primacie casum, Subditus non potest obligari, Quia consensum suum ab eo ad parliamentum prebere non potest; Et, quamquam Rex sic acceptus sit in Anglia plurime tamen partes extere idem non affirmant".

${ }^{158}$ No es claro en qué momento del proceso fueron llamados a declarar estos testigos. Según el relato de Roper, W., cit. (n. 12), p. 71, ello ocurrió sólo una vez terminada la defensa completa de Moro del cargo. Para Derret, J., cit. (n. 17), p. 68, resulta más congruente con el procedimiento pensar que su deposición se produjo después de la negación de Moro de los hechos y antes de la exposición de los argumentos de derecho contra el cargo (submissions). Por nuestra parte, y teniendo como base la reconstrucción de los procesos por traición de esta época efectuada por Bellamy, J., cit. (n. 18), p. 150, nos inclinamos por unir toda la prueba 
no ratificaron sus dichos; Southwell dijo que como su encargo era confiscar los libros no se había detenido a escuchar la conversación entre Rich y Moro; Palmer declaró, igualmente, que había estado tan ocupado echando los libros en un saco que no había prestado atención a lo que hablaban ${ }^{159}$.

A pesar del fracaso de la deposición de los testigos complementarios, el cargo siguió en pie, ya que las reglas de prueba entonces vigentes admitían que un sólo testimonio fuera prueba suficiente de los hechos imputados ${ }^{160}$.

Por ello, al ofrecer la Comisión la palabra al acusado, Moro impugnó el testimonio de Rich con todos los medios de persuación de que disponía ${ }^{161}$. Lo hizo por medio de un juramento, bien seguro de que la audiencia sabía la importancia que le daba a este acto que incluso estaba dispuesto a arriesgar su vida por no jurar contra su conciencia: "Señores - alegó-, si fuera yo un hombre al que no le importara mucho un juramento, no me haría falta, como es bien sabido, comparecer aquí en este lugar, en este momento, o estar como persona acusada en este caso. Y si este juramento vuestro, señor Rich, es verdadero, entonces ruego que nunca vea yo a Dios cara a cara, lo que no diría, si fuera de otro modo, ni para ganar el mundo entero" ${ }^{162}$.

Enseguida, pasó a denunciar el poco crédito que debía prestarse a una persona como Rich, a la que conocía desde su juventud: "La verdad, señor Rich, estoy más apenado por vuestro perjurio que por mi propio peligro ("I am sorrier for your perjury than for my own peril'). Y tenéis que saber que jamás, ni yo ni nadie que yo

testimonial en un solo momento, tanto la de Rich como la de sus acompañantes, antes de que los comisionados le ofrecieran la palabra al acusado para defenderse de ella.

${ }^{159}$ Cfr. Roper, W., cit. (n. 12), p. 71. Es curioso que los dos testigos presentados a favor de la acusación no apoyaran el testimonio de Rich. Según Moro, C., cit. (n. 15), p. 252, Palmer, era un "hombre del Señor Secretario", esto es, del Secretario del rey, Thomas Cromwell. La más moderna biografía de Cromwell compuesta por el historiador Robert Hutchinson, señala que ambos acompantes de Rich eran "Cromwell's men”: Hutchinson, Robert, Thomas Cromwell. The Rise and Fall of Henry VIII's Most Notorius Minister (New York, 2009), p. 75. Debe descartarse que Moro haya podido contrainterrogarlos y forzarlos a declarar que no escucharon la conversación, ya que el acusado carecía de esta facultad: cfr. BELLAMY, J., cit. (n. 18), p. 160. DeRret, J., cit. (n. 17), p. 68, da varias posibles explicaciones: quizás se alarmaron con las graves y solemnes palabras de Moro contra Rich y evitaron testificar contra él; quizás dudaron a último minuto si lo que escucharon en la celda estaba conforme con lo afirmado en el texto de la acusación. REYNOLDS, E., cit. (n. 16), p. 117, sostiene que la explicación más probable es la más simple: prefirieron decir la verdad y no perjurar.

${ }^{160}$ No mucho después del juicio de Moro se aprobó la exigencia de dos testigos para apoyar una acusación de traición. Un estatuto dictado durante el reinado de Eduardo VI: 5 \& 6 Ed. 6, c. 11, estableció que debían ser dos los testigos acusadores, los que habían de declarar en persona ante el acusado. Bellamy, J., cit. (n. 18), p. 154, piensa que una de las razones de este estatuto fue la reacción contra las leyes de traición de Enrique VIII.

${ }^{161}$ Restando credibilidad al testigo, Moro prepara la mente del tribunal para un eventual alegato de fondo. Parece haber sido ésta una práctica normal: cfr. Derret, J., cit. (n. 17), p. 67.

${ }^{162}$ Roper, W., cit. (n. 12), p. 68. Fue un juramento no reconocido legalmente, ya que a Moro no se le permitió jurar su inocencia como medio para defenderse, pero moralmente obligatorio: cfr. Byron, Brian, The Fourth Count of the Indicment of St. Tomás More, en Moreana, 10 (1966), p. 39. 
sepa, os hemos tenido por un hombre de tal reputación que en cualquier asunto de importancia yo o cualquier otro nos hubiéramos dignado comunicároslo en conversación. Y yo, como sabéis, no hace poco que os conozco y conozco vuestra conducta porque os he conocido desde vuestra juventud. Durante largo tiempo vivimos los dos en la misma parroquia en donde, como vos mismo podéis contar (siento el que me forcéis a decirlo) eráis tenido por muy ligero de lengua, un gran jugador de dados, y de fama no recomendable. Y así pensaban también en vuestra casa en el Temple, el lugar más importante en vuestra educación"163.

A continuación, Moro hizo ver a los comisionados lo inverosímil que resultaba creer que lo que con tanto cuidado reservó del conocimiento de todos y que no confidenció a nadie, ni a su propia familia, iba a darlo a conocer de una forma tan liviana a alguien de tan poco crédito como Rich: “¡acaso puede parecer como algo probable a sus honorables señorías que yo, en una causa tan grave, me pasara tan temerariamente como para confiar en el señor Rich, un hombre al que siempre he tenido por tan poco veraz como han escuchado sus señorías, y que por encima de mi soberano señor el rey o de cualquiera de sus nobles consejeros, le hubiera comunicado a él los secretos de mi conciencia en lo que toca a la Supremacía del rey? ¿La única cosa y algo en mis manos por tanto tiempo deseado? ¿Algo que nunca revelé ni revelaría después de ese estatuto, ni a su misma Alteza el rey ni a ninguno de sus honorables consejeros que, como no es desconocido por sus señorías, fueron enviados de parte suya a verme en la Torre con ningún otro propósito sino ése? ¿Acaso puede entonces eso, en vuestro juicio, mis lores, tener alguna probabilidad de ser verdad?"164.

Después de estas alegaciones de hecho en contra la veracidad del testimonio, Moro intentó convencer al Tribunal de que no se había conseguido un caso que pudiera en derecho someterse al veredicto de un jurado penal. Para ello realizó al menos cinco "submissions"165.

La primera de estas submissions fue que la palabra "maliciose" fue insertada deliberadamente en la ley para calificar el acto o palabra constitutiva de traición y que la evidencia del solo testigo Rich no proporciona una prueba de que el acusado habló maliciosamente. Los dichos que se le imputan se vertieron en una conversación con casos hipotéticos, al estilo de los ejercicios con los que se entrenan los abogados (los "motos" de los "Inns of Court"). Alega Moro: "Y aún si así hubiera sido de verdad, mis lores, como ha jurado el señor Rich, viendo que fueron cosas habladas en una charla íntima, secreta, sin afirmar nada, y solamente inventando casos sin otras circunstancias injuriosas, no puede en justicia ser

${ }^{163}$ Roper, W., cit. (n. 12), p. 68. Moro hace referencia a la Academia de Leyes llamada Middle Temple, una de las cuatro existentes en la época donde se formaban los futuros abogados.

${ }^{164}$ Roper, W., cit. (n. 12), pp. 68-69. Derret, J., cit. (n. 17), pp. 67-68, hace notar la habilidad de Moro que intentaba así desacreditar a Rich frente a varios de los miembros de la Comisión que habían sido interrogadores suyos en la Torre y a los cuales nunca quiso confiar sus razones para denegar el juramento.

${ }^{165}$ Seguimos aquí la sistematización que hace Derret, J., cit. (n. 17), pp. 68-70. 
aceptado como si hubiera hablado 'maliciosamente'. Y en donde no hay malicia, no puede haber ofensa" ${ }^{166}$.

La segunda submissio dice relación con la necesidad de que la palabra "malicia” fuera interpretada restrictivamente en el texto de la ley. Así, Moro sostiene que "malitia" en la ley de traiciones debe interpretarse como "malevolentia" y no como simple pecado, ya que de lo contrario nadie podría librarse de incurrir en las penas de la traición: "Y además de esto, jamás podré pensar, mis lores, que tantos ilustres obispos, tantos nobles personajes, $y$ tantos otros hombres respetables, virtuosos, sabios u doctos como estaban reunidos en el Parlamento cuando se hizo ese decreto-ley, tuvieron en algún momento la intención de castigar a alguien con la muerte en quien podían encontrar malicia alguna -entendiendo malitia como malevolentia-; porque si por malitia se entiende generalmente 'pecado', no hay entonces ningún hombre que pueda excusarse a sí mismo: "Quia si dixerimus quod peccatum non habemus, nosmet pisos seducimos, et veritas in nobis non est" 167 .

En la tercera submissio el acusado hizo uso de la analogía con la Ley de entradas violentas (Statute of Forcible Entry). Así como para aplicar esta ley no basta con probar el ingreso a una propiedad sino que se hizo violentamente: "forcibly", tampoco puede haber traición si no se prueba que se actuó o habló maliciosamente: “...esta palabra 'maliciosamente' tiene relevancia en el estatuto -como la palabra 'violencia' la tiene en el estatuto sobre entradas con violencia. Por este estatuto, si un hombre entra pacíficamente, y no echa afuera a su adversario con violencia, no comete ofensa alguna. Pero si lo echa fuera violentamente, entonces, según ese estatuto es una ofensa, y por tanto será castigado por esa cláusula, 'con violencia"” 168 .

Una cuarta submissio hace ver que no pueden emplearse hechos extraños y singulares como prueba de una presunción de malicia, mientras que, por el contrario, de la larga carrera de Moro como servidor del rey debe presumirse justamente lo contrario: afecto, gratitud y lealtad al rey. Declaró Moro: “Además de esto, la abundante bondad de su alteza el rey que ha sido para mí de tantas maneras mi buen señor y amable soberano, que me ha querido con tanto afecto y ha confiado en mí desde la primera vez que entré en su noble servicio con el honor de ser dignamente admitido en su honorable Consejo Privado, y elevándome de la manera más magnánima a puestos de gran dignidad y confianza, y finalmente a ese puesto importante de ser su gran canciller (algo que nunca antes concedió a un laico), el puesto más elevado que hay en este noble reino después de su propia dignidad

${ }^{166}$ Roper, W., cit. (n. 12), p. 69. Moro alegó de esta forma una especie de privilegio profesional forense: de acuerdo al protocolo de los "Inns of Court" donde se formaban y practicaban los abogados los casos eran siempre debatidos hipotéticamente aunque se acercaran mucho a situaciones reales; siendo hipotéticas las opiniones que se daban, ellas no implicaban prejuzgamiento para los jueces o senior barristers que participaban en el debate y que podían después ser llamados a conocer un caso real similar al hipotético: cfr. GUY, J., cit. (n. 25), p. 192.

${ }^{167}$ Roper, W., cit. (n. 12), p. 69. Cita la primera carta de San Juan: "Si decimos que no tenemos pecado, nos engañamos y la verdad no está en nosotros” (1 Juan 1,8). Derret, J., cit. (n. 17), p. 69, n. 73, apunta que la cita de textos de la Sagrada Escritura era normal en los alegatos del common law de la época.

${ }^{168}$ Roper, W., cit. (n. 12), pp. 69-70. 
real, tan por encima de lo que merecen mis méritos y pueden mis cualidades y, por consiguiente, honrado y exaltado por su incomparable benevolencia por espacio de más de veinte años mostrando continuamente su favor hacia mí. Y, hasta que, debido a mi humilde petición, fue el placer de su Alteza darme permiso, con el favor de su majestad, para dedicar el resto de mi vida en el proveimiento de mi alma en servicio de Dios - por su bondad especial, descargarme y aliviarme de ese peso-, de la manera más benigna amontona sobre mí continuamente más y más honores. Todo esto, como digo, que la bondad de su alteza tan generosamente y por tanto tiempo ha extendido hacia mí, sería en mi cabeza, mis lores, suficiente para rechazar esta calumniosa conjetura tan inicuamente imaginada por este hombre en mi contra"169.

Una quinta y última submissio invocó el acusado: si lo que se quiere configurar como malicia es su negativa a jurar la Ley de Sucesión, esto no puede ser admitido en derecho ya que por ello él ya está cumpliendo una condena a prisión de por vida y ha sufrido la confiscación de sus bienes ${ }^{170}$.

Las alegaciones de Moro por desacreditar el testimonio de Rich y para invalidar el cargo por razones de derecho, no fueron atendidas por la Comisión de Oyer et Terminer. Según estos jueces la prueba era suficiente para que fuera sopesada por un jurado que debía pronunciarse sobre si Moro era culpable o no de haber hablado en contra del título del rey de ser cabeza suprema de la Iglesia.

Todo el juicio finalmente descansaba en la palabra de Richard Rich sobre que lo que sucedió en la celda de Moro el 12 de junio de 1535. La historia ha intentado escudriñar qué fue exactamente lo que sucedió ese día y cómo se desarrolló realmente la conversación. Las fuentes existentes son la acusación, cuyo relato ya hemos visto, un acta que se hizo después de la entrevista y que sirvió para preparar la acusación y que se conserva parcialmente pues en parte ha sido mermada por los avatares del tiempo ${ }^{171}$, y el relato Roper en su biografía de Moro ${ }^{172}$. El acta es coincidente en lo medular con la acusación ${ }^{173}$ salvo en un párrafo que se contiene

${ }^{169}$ Roper, W., cit. (n. 12), p. 70.

${ }^{170}$ Derret, J., cit. (n. 17), p. 70. Aunque no hay evidencia directa de que Moro lo haya mencionado, Derret señala que estaba invocando una máxima del Common Law que manifiesta el principio del "non bis in idem: nemo debet bis punire pro uno delicto".

${ }^{171}$ El documento se encuentra en el archivo llamado Letters and Papers of Henry VIII, vol. 8, No 814, 2, ii (P.R.C. S. P. 2/Folio R, bajo el título "The effect of the [ilegible] between Richard [ilegible] and the said Sir Tomás More in presence of [ilegible] Edmud Walsingham, Richard Southwell, [negro] Palmer and [negro] Derlegth" pero había pasado inadvertido a los historiadores hasta que Reynolds notó su importancia y publicó el descubrimiento en el primer número de la revista Moreana: Reynolds, E. E., An Unnoticed Document, en Moreana, 1 (1963), pp. 12-17. También puede verse a Derret, J., The 'New' document on Tomás More's Trial, en Moreana, 3 (1964), pp. 5-22.

${ }^{172}$ Roper, W., cit. (n. 12), pp. 66-67, la relación de los casos supuestos es la misma, salvo que se añade uno que Rich habría planteado a Moro, el de si una ley del Parlamento lo declarara a él como papa, ante el cual Moro habría contestado proponiendo el caso de la ley que ordenara que Dios no fuera Dios. Reynolds, E., cit. (n. 16), p. 110, supone que este caso fue eliminado en el testimonio escrito y luego de la acusación porque no parecía prudente mencionar al papa en un informe que podría ser visto por el rey.

${ }^{173}$ Según el texto reconstruido por Reynolds, E. cit. (n. 171), p. 14, el acta relata que 
en ella y que fue eliminado de la acusación: son unas palabras de despedida de Rich en la que le dice "Bien, sir, que Dios os sostenga, ya que yo veo que vuestra mente no cambiará por lo que temo un gran peligro para vos porque yo supongo que vuestra reticencia [concealment] a la cuestión que se os ha sido preguntada es una gran ofensa como otras [...]. Que Jesús os envíe su mejor gracia” ${ }^{174}$.

Según el relato de Roper, Rich habría informado que Moro al tercer caso, había contestado: "tampoco podría el Parlamento hacer al rey cabeza suprema de la Iglesia" ${ }^{175}$.

¿Cuál de estas versiones es la auténtica? Los historiadores se han dividido. Para algunos, el acta de la conversación y la acusación contienen en sustancia lo que Moro dijo y que no era más que la negación de que el Parlamento tuviera competencia para otorgar al rey el título de cabeza de la Iglesia, lo que indirecta pero claramente significaba negar el nuevo título del rey, de modo que Rich no habría mentido en el juicio ${ }^{176}$. Para otros, la vehemente reacción de Moro que acusó a Rich de perjurio y que incluso se atrevió a jurar que era falso bajo pena de no ver jamás a Dios, hacen difícil aceptar que la versión de Rich haya sido genuina ${ }^{177}$. Se añaden argumentos como que el acta revela que el mismo Rich pensó

"Whereunto the said Moro said that the cases were not like by cause that a King [...] y be made by Parliament to wich act any [...] Subjects being of a Parliament may give his cosnent but to he case [...] a Subject can not be bound by cause he cannot give his cause [consent?] [...] him [...] Parliamen. Saying further that although the King were accepted in England yet most utter parts [outer or foering countreis] do not affirm the same".

${ }^{174}$ El texto reconstruido por REYNOLDS, E. cit. (n. 171), p. 15, es del siguiente tenor: "Well, Sir, God comfort you, for I see your mind will not change wich I fear will be very dangerous to you for I suppose your concealment to the question that hath been asked of you is as high offence as other that hath [...] An thus Jesu send you better grace". También en REYNOLDS, E., cit. (n. 16), p. 111.

${ }^{175}$ Roper, W., cit. (n. 12), p. 67.

${ }^{176}$ Es la tesis sostenida por Derret, J., cit. (n. 171), pp. 5-22. Según este autor, la frase final del acta, si bien puede revelar que Rich no advirtió lo que había obtenido, no significa que Moro no haya en verdad denegado la competencia del Parlamento para atribuir el título de cabeza suprema de la Iglesia, lo cual sí pudo ver Cromwell. Si no se traspasó a la acusación habrá sido porque no era necesaria e incluso podría ser usada en favor del acusado. La indignación de Moro la atribuye, no a que mienta en el juicio, sino a que él sostiene que no habló maliciosamente sino discutiendo sobre casos legales en abstracto y que él no habría negado el título del rey como cabeza suprema de la Iglesia que era lo que constituía acto de traición. Según este autor, la denegación del título aunque no directa era implícita, tal como si alguien sostiene que no dijo de una persona que era un bastardo, sino solamente que era hijo de una madre no casada. Por ello, Moro, para los efectos de la ley y en la apreciación de un jurado de legos, habría incurrido en los actos penados por la Ley de Traición. En este sentido, Marius, R., cit. (n. 22), p. 502, piensa que al parecer Moro, cansado y deprimido por la confiscación de sus libros, no pudo evitar caer en la trampa que le tendió Rich.

${ }^{177}$ Algunos biógrafos de Moro han asumido simplemente que Rich, instruido por Cromwell, cometió perjurio y mintió en la declaración para la acusación y en el proceso: cfr. Moro, C., cit. (n. 15), p. 253; Berglar, P., cit. (n. 21), p. 377. Otros sostienen que lo de Rich más que una falsedad absoluta fue una distorsión y manipulación de una conversación que tuvo lugar realmente: STAPLETON, T., cit. (n. 14), p. 176, sostiene que quizás la respuesta de Moro que aparece en la acusación no es completamente verdadera. Pero a favor de la veracidad de Moro debe tenerse en cuenta la firmeza de su aseveración y el juramento que prestó 
al terminar la entrevista que Moro no había salido de su silencio, que dos días después Cromwell y otros volvieron a interrogarlo sobre si aceptaba la Supremacía, lo que no se entiende si Moro hubiera descubierto su pensamiento a Rich, y que en esta parte de la acusación las palabras figuran en latín y no en inglés como se hace en los otros casos, lo que denota que aquí no hubo transcripción literal de lo que el acusado había dicho ${ }^{178}$.

Lo cierto, aceptado por todos, es que la visita del "solicitor general" y su conversación con Moro fue planeada como una trampa para buscar palabras incriminatorias. Pocos días antes el mismo Rich había conseguido con el mismo método una declaración de Fisher en contra del título del rey. En la acusación de éste se afirma que el obispo contestó a Rich: "El rey nuestro soberano señor no es la suprema cabeza en la tierra de la Iglesia de Inglaterra". El obispo fue engañado ya que Rich le hizo creer que estaba en una situación privilegiada en la que lo que afirmara no sería usado como testimonio en su contra.

Pero la trampa no funcionó tan bien con Moro. Incluso confiando que el texto de la reprodujera fielmente la conversación, las palabras que atribuye a Moro están muy lejos de afirmación categórica de Fisher Se observa que la contestación de Moro no es categórica, pues no dice que el Parlamento no pueda nombrar al rey como cabeza de la Iglesia sino que, de hacerlo, ello no sería obligatorio para los otros países que conforman la cristiandad y esto es algo que nadie podía negar. Según puede interpretarse, por la fórmula que aparece en la acusación Moro estaba dispuesto a reconocer que la cuestión de la sucesión era de competencia del Parlamento: "el pueblo a través de Parlamento puede poner o deponer al rey”, pero que no tendría atribución para otorgar supremacía religiosa vinculante para todos porque esto es algo que ningún país puede decidir por sí mismo sin el consentimiento de los demás ${ }^{179}$. No es raro entonces que en el acta preparatoria de la acusación aparezca que Rich pensó haber fracasado en su intento por hacer hablar a Moro, y es lógico que Cromwell haya suprimido este pasaje cuando hizo transcribir el episodio como parte de la acusación.

Es probable que Rich, al ser llamado a confirmar oralmente lo señalado en la acusación, haya ido más allá de su propio testimonio escrito, sea disimulando que la afirmación de Moro había sido hipotética y como parte de un ejercicio retórico propio de los abogados de poner casos imaginarios que no prejuzgaban opinión sobre situaciones reales ${ }^{180}$, sea declarando que Moro no sólo había dicho que el Parlamento no podría hacer al rey cabeza de la Iglesia de un modo que fuera obligatorio para todos los súbditos de la cristiandad, sino que el rey no podía usar

para garantizarla. BYRON, B., cit. (n. 162), p. 39, argumenta: "La impugnación de Moro a Rich en el juicio fue el ataque personal más devastador que Moro hizo en su vida. ¿Sería esto simplemente una astuta maniobra legal o era que estaba contando la verdad? Conociendo la meticulosa honestidad de Moro, pienso que es imposible creer que condenara tan frontalmente a Rich y su evidencia si no estaba contando la verdad".

${ }^{178}$ Cfr. Reynolds, E., cit. (n. 16), p. 111. Reynolds, E. cit. (n. 171), p. 17, sostiene que el descubrimiento del acta que incluye el pasaje final confirma el perjurio de Rich.

${ }^{179}$ Cfr. Reynolds, E., cit. (n. 16), p. 112.

${ }^{180}$ Es una de las hipótesis sugerida por GUY, J., cit. (n. 25), p. 192, siguiendo a MARIUS, R., cit. (n. 22), pp. 506-508. 
ni reclamar dicho título ${ }^{181}$. Se explicaría así la reacción indignada de Moro y su estremecedor juramento de renunciar a la vida eterna si Rich decía la verdad.

Sea como fuere, lo cierto es que el testimonio del "solicitor general" fue considerado suficiente para construir el cargo. El presidente de la Comisión convocó a los 12 hombres designados como jurado para que emitieran su veredicto sobre si el acusado había hablado maliciosamente contra el título del rey de ser cabeza suprema de la Iglesia en Inglaterra, para lo cual debían valorar el único testimonio de Richard Rich.

\section{El Veredicto del JuRAdo y la DEFENSA Final: “I AM NOT BOUND tO CONFORM MY CONSCIENCE TO THE COUNCIL OF ONE REALM AGAINST THE General Council of Christendom”}

Los doce miembros del jurado se retiraron a deliberar, pero en breve tiempo: un cuarto de hora, regresaron y dieron a conocer a los jueces su decisión: guilty ${ }^{182}$; Moro era culpable de haber hablado maliciosamente contra el título del rey de ser cabeza suprema de la Iglesia.

A pesar de la debilidad de los cargos y del testimonio único y poco creíble de Rich, era casi imposible que un jurado pudiera emitir un dictamen de inocencia frente a una comisión presidida por el mismo lord canciller e integrada por el padre y el hermano de Ana Bolena, el cuñado del rey y hasta el mismo Tomás Cromwell ${ }^{183}$. Es poco probable que Moro pensara que podía ganar este juicio en buena lid, pero tenía que defenderse de la mejor manera posible para dejar en evidencia la injusticia de la acusación y mantener su criterio de no presumir de mártir.

No obstante, existía un trámite que permitía una última oportunidad al reo, incluso después de haberse emitido el veredicto. El presidente del Tribunal una vez recibido el dictamen de culpabilidad, debía preguntar al prisionero si tenía alguna razón que alegar por la cual la condena no debía serle aplicada ${ }^{184}$. El jurado se había pronunciado sobre los hechos, pero ahora el acusado podía plantear cuestiones de derecho sobre la validez de la acusación, de sus bases o de la ley en la ella se

\footnotetext{
${ }^{181}$ MARius, R., cit. (n. 22), p. 507, señala que Rich pudo haber ido más allá de la acusación y de su propio informe. Otra interpretación es la que da BYron, B., cit. (n. 162), pp. 42, para quien es Roper quien da la versión más verosímil. Después de decir que el Parlamento no podría nombrar a Rich como papa, Rich utilizó la expresión cabeza de la Iglesia en el sentido de papado, y Moro contestó que tampoco el Parlamento podría nombrar al rey "Head of the Church", esto es, papa de toda la Iglesia. Rich en su informe, del que da constancia el acta y que luego pasó a la acusación, distorsiona la cuestión contestada, de una sobre el papado a otra sobre la Supremacía del rey sobre la Iglesia de Inglaterra.

${ }^{182}$ The Paris News Letter cit. (n. 4), p. 263. El texto en francés intenta reproducir la palabra inglesa: "Gylti"

${ }^{183}$ ReYNOLDS, E., cit. (n. 16), p. 119.

${ }^{184}$ ReynOLDS, E., cit. (n. 16), p. 119, ilustra esta parte del proceso con un informe del juicio de Sir Christopher Blunt y otros cuatro en marzo de 1600, en el que expresamente se contempla el trámite.
} 
fundaba. El propósito de este allocutus era, pues, "dar al criminal convicto una oportunidad para intentar detener la sentencia sobre un punto de derecho"185.

El presidente de la Comisión, lord Audley olvidó esta parte del proceso y precipitadamente intentó comenzar a dictar la sentencia con la pena que correspondía $^{186}$, pero Moro no lo dejó ir adelante: "Mi lord -le dijo amablemente-, cuando trabajaba yo en la administración de la justicia, se acostumbraba en estos casos a preguntar al prisionero antes de condenarle por qué no se le debería condenar" 187 .

Audley accedió a la petición de Moro y lo autorizó para exponer las razones por las cuales pensaba que no debía ser condenado.

El discurso que viene de Moro ha sido recogido de modos diferentes por las fuentes y de allí que se le haya interpretado también de diversas maneras ${ }^{188}$. Para algunos, se trata más que de un alegato jurídico de un testimonio para la posteridad de las razones por las cuales en conciencia no podía someterse a las leyes de Enrique VIII; a sabiendas de ser ya declarado culpable la precaución de no provocar con temeridad el martirio declarando expresamente su pensamiento no tenía sentido e incluso era necesario ponerlo de manifiesto públicamente. Esta posición se ve reforzada por el pasaje inicial del discurso que recoge la temprana narración contenida en la Paris News Letter: "Puesto que soy así condenado -vea y sepa Dios cómo- quiero hablar libremente de vuestro estatuto para descargar mi conciencia" ${ }^{189}$. Este preámbulo no aparece, en cambio, en el relato de Roper, por lo que el discurso asume la característica de un último esfuerzo para evitar la condena y convencer a la Comisión de que la acusación y la ley no pueden ser usadas legítimamente para considerarlo traidor. El contenido del discurso no debe ser, por tanto, interpretado sólo como testimonio de las convicciones morales de Moro, sino como un alegato legal con argumentos propiamente jurídicos. Cumplía efectivamente Moro con el propósito del trámite procesal que él mismo había pedido que se le concediera como derecho de todo reo ("allocution") y que él ejercía interpondiendo un "arrest of judgment" ${ }^{190}$, derechos que hasta el día de

${ }^{185}$ Derret, J., cit. (n. 17), p. 70.

${ }^{186}$ ReYNOLDS, E., cit. (n. 16), pp. 119-120, señala que es posible que su omisión se haya debido a inexperiencia o a nerviosismo motivado por estar juzgando a su mismo predecesor. También puede ser que estuviera instruido por el rey para que no dejara hablar mucho a Moro, como se sabe fue su deseo para el momento de la ejecución.

${ }^{187}$ Roper, W., cit. (n. 12), p. 71.

${ }^{188} \mathrm{La}$ diversidad puede deberse a que el alegato posterior a la declaración de culpabilidad por el jurado era raro, ya que la mayoría de los prisioneros en esa fase prefirieron pedir clemencia. Según Bellamy, J., cit. (n. 18), p. 175, entre los pocos prisioneros que alegaron contra el veredicto aduciendo que la acusación era insuficiente, "el más famoso por lejos fue Tomás Moro".

${ }^{189}$ The Paris News Letter cit., p. 263. Según Reynolds, E., cit. (n. 16), p. 120, este pasaje es la clave de la posición de Moro. En el se basa también Stapleton, T., cit. (n. 14), p. 196, para sostener que, al ser sentenciado, Moro vio que era voluntad de Dios que fuera al martirio, y ya no tenía objeto tratar de evitarlo mediante el silenciamiento de las razones de su oposición a las leyes de Enrique VIII. En el mismo sentido, el relato de Pole, R., cit. (n. 8), pp. 226-227.

${ }^{190}$ Así, Derret, J., cit. (n. 17), p. 70, señala que se trata de un allocutus que era otorgado 
hoy conservan los imputados en los procesos penales del sistema anglosajón ${ }^{191}$. Pareciera que esta última es la interpretación que debe prevalecer, sin perjuicio de que Moro sabía que, si sus argumentos dirigidos al jurado no habían tenido ningún efecto, menos podrían ahora estos liberarle de la muerte, de modo que junto con estar actuando como abogado en su defensa, también dejaba testimonio para el futuro de que su resistencia no había tenido por motivo ni la deslealtad para con la corona pero tampoco una creencia irracional y caprichosamente testaruda ${ }^{192}$.

Comienza, entonces, a exponer las razones por las cuales sostiene que la acusación debe ser considerada insuficiente, ya que se funda en una ley que debe ser considerada nula y no vinculante entre cristianos.

La primera alegación para evitar la condena es dirigida contra la Ley de Traiciones en la que se fundó la Acusación. Se trataría de una ley ineficaz por contraria ("repugnant") al Derecho de Dios y de la Iglesia: "Mi lord, ya que esta acusación está fundada sobre una ley del Parlamento directamente opuesta a las leyes de Dios y de su santa Iglesia, cuyo gobierno supremo o alguna porción de él, ningún soberano temporal puede asumir para sí por ninguna ley, pues pertenece por derecho a la Sede de Roma -una preeminencia espiritual otorgada como prerrogativa especial por la boca de nuestro mismo Salvador personalmente presente en la tierra, sólo a San Pedro y a sus sucesores, los obispos de la misma Sede- en consecuencia, entre cristianos, resulta insuficiente en derecho para denunciar a ningún cristiano" ${ }^{\prime 193}$. Moro señaló que había llegado a esta conclusión no frívolamente sino después de una larga reflexión y estudio de las fuentes más autorizadas. Dijo que por lo menos llevaba siete años dirigiendo sus estudios y reflexiones sobre puntos como el de la autoridad del papa $^{194}$ y que no había leído

al convicto para impugnar la sentencia por medio de un "arrest of judgement", sobre un punto de derecho. En el mismo sentido Bellamy, J., cit. (n. 18), pp. 174-175.

${ }^{191}$ Hasta el día de hoy existen en el Derecho procesal penal anglosajón las figuras de la "allocution" y del "arrest of judgment". La "allocution" son las palabras que dirige el juez al acusado, después del veredicto del jurado y antes de dictar sentencia, por las que le pide que manifieste lo que estime conveniente en su propia defensa. El "arrest of judgment". consiste en la solicitud de suspensión del pronunciamiento de una sentencia o de nulidad de la causa por un defecto de forma: cfr. Álcaraz Varó, Enrique - Hughes, Brian, Diccionario de términos juridicos/ A Dictionary of Legal Terms (Inglés-Español/Spanish-English) (10a edic., Madrid, 2007), voz "Allocution", p. 44; y voz "Arrest", p. 58.

${ }^{192}$ Señala Marius, R., cit. (n. 22), pp. 509, que parece más probable pensar que Moro usó la moción del "arrest of judgment"., "como una ocasión para hacer un discurso y dar a conocer a la audiencia de modo inequívoco las razones de su muerte. El contexto de la exposición de Moro fue el de una corte judicial y la tradición de un juicio capital. Pero el espíritu de sus palabras fue el de los mártires cristianos que habían muerto en la arena, confesando sus creencias a las multitudes".

${ }^{193}$ ROPER, W., cit. (n. 12), pp. 71-72.

${ }^{194}$ Harpsfield, N., cit. (n. 13), p. 195. Reynolds, E., cit. (n. 16), p. 127, precisa que Moro estudió dos problemas relacionados: la supremacía de la Santa Sede y si un príncipe secular podía ser la cabeza espiritual en su reino. Los siete años referidos en el juicio deben referirse a este segundo problema, ya que respecto del primero en carta a Cromwell de marzo de 1534, Moro dice que ha estudiado la primacía del papa por diez años y más. Coincide este aserto con la carta de Moro dirigida a Nicholas Wilson: cfr. carta al doctor Nicolas Wilson, 1534, en Moro, T., Cartas cit. (n. 11), pp. 67 y ss. Señala Reynolds, E., cit. (n. 16), p. 128, que la 
en ningún doctor aprobado por la Iglesia que un Señor temporal pueda o deba ser cabeza de lo espiritual ${ }^{195}$.

Debe considerarse que lo anterior hoy puede sonar como una apelación a razones extralegales, porque se piensa que la ley divina y la ley canónica son extrañas a los ordenamientos legales del estado, pero en el tiempo de Moro ello aún no era así, y existía un consenso total en que la ley divina y la ley canónica eran tan fuentes del Derecho como las leyes del Parlamento y de las autoridades públicas. Ninguno de los acusadores de Moro habría pretendido discutir la base de la argumentación de que las leyes del Parlamento no podían violar la ley de Dios ni la de la su Iglesia y que si lo hacían no podían ser usadas para acusar a un cristiano, como lo eran todos ellos. Es de notar que Moro se esmera por invocar en su favor el testimonio de la Escritura bíblica ${ }^{196}$ y la de todos los antiguos doctores: un laico no puede ser cabeza de la Iglesia de Cristo. Apelaba también a la razón, para convencer a los jueces que una ley irracional no podía ser válida ${ }^{197}$.

En este punto, lord Audley, quizás preocupado por el efecto que estaban produciendo las palabras del acusado, lo interrumpió y le enrostró que se encontraba en absoluta minoría en cuanto a los más sabios del reino: "viendo que todos los obispos, las universidades, y los más doctos de este reino estaban de acuerdo con esta ley, era muy de asombrarse que él solo, en contra de todos ellos, de manera tan obstinada la rechazara y con tanta vehemencia razonara contra ella"198.

Frente al argumento de la mayoría, según el relato de Roper, el acusado respondió: "Si el número de obispos y universidades es tan relevante como parece a su señoría, veo entonces poca causa, mi lord, de que eso deba producir cambio alguno en mi conciencia. Pues no tengo duda alguna de que, aunque no en este reino, en toda la cristiandad, de entre los doctos obispos y hombres virtuosos que aún viven, no será una pequeña parte los que piensan como yo en el asunto”. Si se extendía la revisión de opiniones más allá del reino de Inglaterra, difícilmente podría decirse que Moro estaba solo y en una posición obstinada. Pero el acusado no se detuvo aquí, ya que era consciente que la Iglesia no sólo esta formada por los bautizados vivos, sino también por los difuntos: "Y si hablara de los que ya han muerto, de los cuales muchos son ahora santos en el cielo, estoy seguro de que la mayor parte de ellos mientras vivían pensaron en este caso de la misma manera que pienso yo ahora". La conclusión era clara: el consenso (aunque fuera libre y no obtenido por amenazas) de un solo reino no puede obligar por sobre el consenso general de toda la Iglesia: "Y por consiguiente, no estoy obligado, mi lord, a adaptar mi conciencia al concilio de un reino en contra del concilio

decisión de Moro "fue el resultado de una prolongada consideración y consulta y, podemos estar seguros, de oración”.

195 The Paris News Letter cit. (n. 4), p. 263; “Relación castellana”, cit. (n. 7), p. 398.

${ }^{196}$ Derret, J., cit. (n. 17), p. 71.

${ }^{197}$ Derret, J., cit. (n. 17), p. 71.

${ }^{198}$ Roper, W., cit. (n. 12), p. 73. Aunque Roper coloca la interrupción más adelante, parece más probable situarla en el momento señalado en el texto principal: seguimos el orden sugerido por DeRreT, J., cit. (n. 17), p. 71. 
universal de la cristiandad ("am I not bound, my lord, to conform my conscience to the Council of one realm against the General Council of Christendom") ${ }^{199}$.

Más aún, ya con vehemencia, señaló: "por un obispo de los vuestros, yo tengo a mi lado más de cien santos; y por cada Concilio o Parlamento de los vuestros (Dios sabe de qué manera se ha hecho), yo tengo todos los Concilios realizados durante los últimos mil años; y por este reino, yo tengo a Francia y todos los otros reinos cristianos" 200 .

El duque de Norfolk, quizás sintiéndose aludido por las fracasadas gestiones que había realizado para que Francia apoyara la política contra Roma de Enrique VIII ${ }^{201}$, le espetó que ahora sí se mostraba claramente su malicia ${ }^{202}$. Moro negó una vez más que procediera maliciosamente, y contestó: "Mi lord, lo que he dicho ha sido necesidad y para la declaración de mi conciencia y satisfacción de mi alma y de lo que hago apelo a Dios como testigo, el único escrutador de los corazones humanos" 203 .

Prosiguió, entonces, a proporcionar más argumentos contra la validez de las Leyes de supremacía y de traiciones, por si su contradicción a las leyes de Dios y de la Iglesia no fuera considerada suficiente.

El nuevo punto alegado es la falta de competencia del Parlamento para adoptar regulaciones como las impugnadas. Según Roper, Moro "explicó que este reino, no siendo nada más que un miembro y una parte pequeña de la Iglesia, no podía hacer una ley que no estuviera de acuerdo con la ley general de la Iglesia Católica y universal de Cristo; como tampoco la ciudad de Londres, no siendo nada más que un pobre miembro con respecto a todo el reino, hacer una ley que obligara a todo el reino en contra de una ley del Parlamento" ${ }^{204}$. Inglaterra no podía dictar una ley que concierne a toda la comunidad cristiana.

${ }^{199}$ Roper, W., cit. (n. 12), p. 73.

${ }^{200}$ The Paris News Letter cit. (n. 4), p. 263; "Relación castellana”, cit. (n. 7), p. 398. REYNOLDS, E., cit. (n. 16), p. 128, advierte que el documento llamado Novitates tiene una versión que parece más verosímil respecto de la frase "Por cada Concilio o Parlamento de los vuestros"; el texto de la Novitates dice "ac pro uno consilio ac decreto vestro [...]" (por cada concilio y ley vuestros). El cambio tendría importancia según Reynolds ya que pondría de relieve que los comentarios de Moro se referían no tanto al Parlamento sino a la ley o estatuto: ReYNOLDS, E., cit. (n. 16), p. 129.

${ }^{201}$ Cfr. Derret, J., cit. (n. 17), p. 73, quien sugiere que Moro, al mencionar otros reinos cristianos y particularmente a Francia, podría haber querido que se tomara constancia judicial de lo que se estaba haciendo en el exterior.

${ }^{202}$ The Paris News Letter cit. (n. 4), p. 264. Derret, J., cit. (n. 17), p. 73, piensa que puede haber alguna confusión ya que la malicia de Moro estaba ya juzgada por el veredicto del jurado. Señala que, presumiblemente, el duque de Norfolk quería alegar que Moro estaba mostrando su propia determinación de obstaculizar la política del rey al tratar de que se declarara inválida la Ley de Traiciones.

${ }^{203}$ The Paris News Letter cit. (n. 4), p. 264.

${ }^{204}$ Roper, W., cit. (n. 12), p. 72. Derret, J., cit. (n. 17), p. 74, supone que la alusión a la relación entre la Ciudad de Londres y el Parlamento, fue producto de una interrupción de alguno de los jueces, que le habría replicado a Moro que la ciudad de Londres, que él bien conocía, podía aprobar normas obligatorias sin que fuera necesario el consentimiento del Parlamento. A ello, Moro contestó que el punto era que la ciudad no podía derogar una Ley del Parlamento ni limitar su aplicabilidad respecto de los ciudadanos de Londres. Sobre 
Una tercera razón abogó Moro ahora apuntando a la misma constitución del reino. Roper, cuenta, que Moro alegó que la Ley de supremacía, "era contraria tanto a las leyes y estatutos de nuestro propio país todavía no revocados" ${ }^{205}$. Una primera referencia hizo a la Carta Magna citando la norma que garantizaba la autonomía e independencia de la Iglesia: "Quod ecclesia Anglicana libera sit, et habeas omnia iura sua integra et libertates suas illaesas" ("Que la Iglesia de Inglaterra debe ser libre y tener íntegros todos su derechos e ilesas sus libertades: $1^{\text {a }}$ cláusula de la Carta”). Debe ser uno de los primeros precedentes de la invocación del principio que los tiempos modernos conocerán como supremacía constitucional. Moro no sólo alegó la Carta Magna, sino además el juramento que el rey hacía al momento de aceptar la corona de respetarla y de proteger la independencia de la Iglesia, de modo que el estatuto en el que se basaba la acusación resultaba contrario "también a aquel juramento sagrado que siempre prestaban su Alteza el rey todo monarca cristiano, con gran solemnidad, en el momento de su coronación" ${ }^{206}$. Como comenta Derret, Moro hacía ver que los juramentos no sólo limitaban su capacidad de manera individual, sino también para actuar conjuntamente. Si un niño destruía a su padre o un clérigo a su ordinario, cometía traición según el "Common law": ¡cómo podía una asamblea decididamente culpable de traición aprobar una Ley de traiciones? ${ }^{207}$

El acusado terminó su discurso recordando que el pueblo inglés debía la fe cristiana a la intervención directa de la Sede de Roma, de modo que "así como un niño no podía rechazar la obediencia a su propio padre natural, así tampoco podía este reino de Inglaterra rechazar su obediencia a la Sede de Roma. Porque, como San Pablo dijo a los Corintios: 'Os he regenerado, mis hijos, en Cristo' ${ }^{208}$, así podría de verdad decir de nosotros los ingleses San Gregorio, papa de Roma, de quien por medio de San Agustín ${ }^{209}$, su mensajero, recibimos por primera vez la fe cristiana: 'Sois mis hijos porque os he dado la salvación eterna, una herencia mucho más grande y mejor que la que cualquier padre puede dejar a su hijo, y por regeneración os hice mis hijos espirituales en Cristo'"210.

Resumió su alegato final contra la ley diciendo: "Y digo además que vuestra ley ha sido mal hecha, porque vosotros habéis hecho profesión y jurado no hacer nada en contra de la Iglesia, la cual es una sola, íntegra e indivisa en toda la

el tema, cfr. Derret, J. Duncan M., Thomas More and the Legislation of the Corporation of London, en Sylvester, R. S. y Marc'Hadour, G. P. (edits.), Essential Articles for the Study of Thomas More (Hamden, Connecticut), 1977, pp. 49-54.

${ }^{205}$ Roper, W., cit. (n. 12), p. 72.

${ }^{206}$ Roper, W., cit. (n. 12), p. 72.

${ }^{207}$ Derret, J., cit. (n. 17), p. 74.

${ }^{208}$ Moro parece citar de memoria el pasaje de la Carta a los Corintios: I Cor. 4, 15: "Pues aunque tengáis diez mil pedagogos en Cristo, no tenéis muchos padres; he sido yo quien, por medio del Evangelio, os he engendrado en Cristo Jesús".

${ }^{209}$ Moro hace alusión a San Agustín de Canterbury, monje benedictino perteneciente al monasterio de San Andrés de Roma, que fue enviado por el papa Gregorio I, el año 597, para anunciar el Evangelio en Inglaterra. Fue el primer obispo de Canterbury y es considerado el apóstol de Inglaterra.

${ }^{210}$ Roper, W., cit. (n. 12), pp. 72-73. 
cristiandad, y vosotros no tenéis autoridad alguna, sin el consentimiento de los otros cristianos, para hacer una ley o acto del Parlamento contra la dicha unión de la cristiandad"211.

Aunque en el último tiempo se ha querido ver en Moro un héroe de la libertad de conciencia, entendida en un sentido subjetivo y sin referencias a la verdad objetiva, lo cierto es que tal interpretación no se compadece con las mismas afirmaciones del acusado. Su resistencia no puede entenderse como la del fanático irracional, sino como la de quien está profudamente convencido de la justicia de su posición por el apoyo de la opinión común de la Iglesia universal. Como dice Bernard, "lo que dio a Moro confianza de que su propia comprensión era justa y digna de entregar su vida por ella fue que la opinión de la Cristiandad, en su tiempo, y a través de los siglos de la historia cristiana, coincidía con ella. Esencialmente, la postura de Moro fue una defensa de la Cristiandad"212.

\section{Xi. La sentencia: “That if the act of Parliament be not unlawful, THEN IS NOT THE INDICTMENT INSUFFICIENT"}

Terminado el alegato final de Moro, nuevamente Audley titubeó, y antes de proceder preguntó al lord Chief Justice del "King's Bench", lord Fitzjames, si la acusación (el "indictment") podía ser considerada legalmente suficiente o no. Fitzjames contestó con estudiada ambigüedad: "Mis lores, ¡por San Julián!, así solía jurar siempre, tengo que confesar que, según mi conciencia, si la ley del Parlamento no va contra la ley, entonces la acusación no es insuficiente ("My lords all, by St. Julian (that was ever his oath), I must needs confess that if the act of Parliament be not unlawful, then is not the indictment in my conscience insufficient" $)^{213}$.

Sin esperar que algún otro comisionado tomara la palabra para impugnar la validez de la ley en la que se fundaba la acusación, Audley prestando atención sólo a la última parte de la respuesta de Fitzjames, dijo: "Mirad, mis lores, oís lo que

${ }^{211}$ The Paris News Letter cit. (n. 4), p. 264. Esta firmeza en la posición de Moro debió causar gran impresión entre los asistentes al juicio. Sir John Spelman, uno de los miembros de la Comisión de oyer et terminer señala en su relato que: "More stood firmly on the statute of 26 Hen. 8, for he said that the Parliament could not make the king Supreme Head, etc. [Moro se mantuvo firmemente contra el estatuto de $26 \mathrm{Hen}$. 8, porque él dijo que el Parlamento no podía hacer al rey suprema cabeza, etc.”: cfr. ReYNOLDs, E., cit. (n. 10), p. 29.

${ }^{212}$ Bernard, G., cit. (n. 49), p. 148. Más adelante agrega que "Si Moro murió por algo, no fue tanto por el papado, sino por la Cristiandad". Algo parecido afirma MARIUS, R., cit. (n. 22), p. 458, para quien la cuestión principal de la lucha de Moro no fue el papado "sino la unidad de la iglesia y cómo la iglesia escuchaba la voz de Dios”. En realidad, en la concepción de Moro no se pueden escindir ambos conceptos, para defender la Cristiandad, debía defenderse la primacía del Obispo de Roma que le proporciona su unidad y consistencia como comunidad sobrenatural guiada por el Espíritu Santo.

${ }^{213}$ ROPER, W., cit. (n. 12), p. 74. La frase en inglés es: "My lords all, by St Julian (that was ever his oath) I must needs confess that, if the Act of Parliament be lawful, then the Indictment is good enough"; quizás una traducción más acertada de "lawful” es "legítimo, adecuado a Derecho". La afirmación entonces quiere decir que sólo si la ley era legítima o válida jurídicamente la acusación podía ser considerada también eficaz para condenar al acusado. Pero, en verdad, elude el alegato de Moro que fue justamente que la ley no era legítima ni válida. 
mi lord, el Juez Supremo dice"214, tras lo cual inmediatamente dictó sentencia. Se condenaba a Tomás Moro como reo de alta traición a la pena de muerte con los crueles procedimientos reservados para los reos comunes: será arrastrado en un "hurdle" 15 a través de la City de Londres hasta Tyburn, y allí será colgado hasta estar medio muerto y, tras ello, todavía vivo será troceado y se le extraerán las entrañas del cuerpo que se hervirán frente a sus ojos, se le cortarán las partes privadas y la cabeza, el cuerpo se dividirá en cuatro partes, y la cabeza y el cuerpo se colocarán en los lugares que el rey disponga ${ }^{216}$.

Moro permaneció sereno y silente. Los jueces parecían conmovidos y "le propusieron cortésmente que se le concedería audiencia favorable si tenía alguna otra cosa que alegar en su defensa" ${ }^{217}$. Al parecer era una invitación para que, aunque condenado, suplicara la clemencia del rey y un posible indulto ${ }^{218}$.

Moro sabía que cualquier petición en tal sentido estaba vetada por la influencia de Ana Bolena sobre el rey. Quizás por eso, o tan solo a modo de desahogo, el condenado aludió a lo que había causado toda la revolución legislativa de Enrique VIII, y exclamó: "Yo sé bien por qué causa me habéis condenado. Es porque jamás he querido consentir en la materia del matrimonio del rey" ${ }^{219}$.

El acusado ya sólo podía testimoniar su esperanza en la clemencia de Dios y su falta de animosidad contra sus jueces en la tierra: "No puedo decir más, mis lores, sino sólo que al igual que el bienaventurado apóstol San Pablo, como leemos en los Hechos de los Apóstoles ${ }^{220}$, estuvo presente y consintió en la muerte de San Esteban, y guardó las ropas de los que le apedrearon hasta la muerte, y aún así los dos son ahora santos en el cielo, y allí permanecerán amigos para siempre, así también confío de verdad y por eso voy a rezar de todo corazón para que, aunque vuestras señorías han sido ahora aquí en la tierra los jueces de mi condena, podamos luego en el cielo alegrarnos todos juntos de nuestra eterna salvación"221. La Paris News Letter, agrega que Moro terminó estas palabras con una frase referida al rey: "Ruego a Dios que quiera salvar y guardar al rey y le dé buen consejo"222.

El juicio había terminado. Moro, abogado defensor y acusado, lo había perdido, pero al mismo tiempo lo había ganado. Había conseguido demostrar que

${ }^{214}$ Roper, W., cit. (n. 12), p. 74.

${ }^{215} \mathrm{El}$ "hurdle" era una especie de armazón en la que se arrastraba a los condenados por las calles hasta el patíbulo: cfr. AKroYd, P., cit. (n. 24), p. 552.

${ }^{216}$ No obstante, MARius, R., cit. (n. 22), p. 510, piensa que es posible que Audley haya estado facultado para conmutar la pena, de manera que habría dictado sentencia de decapitación. La mayoría de los biógrafos sostiene, en contra, que la conmutación fue decretada con posterioridad por Enrique VIII.

${ }^{217}$ Roper, W., cit. (n. 12), p. 74.

${ }^{218}$ Derret, J., cit. (n. 17), pp. 60-61 y 75, sostiene que la invitación a hablar tenía por motivo permitir al condenado pedir clemencia. REYNOLDS, E., cit. (n. 16), p. 132, piensa que la invitación era irregular, pero que el testimonio de Roper es creíble, ya que es dificultoso pensar que, siendo un abogado experimentado, incurriera en error en este punto.

${ }^{219}$ The Paris News Letter cit. (n. 4), p. 264.

${ }^{220}$ Cfr. Hechos 7, 58-60.

${ }^{221}$ Roper, W., cit. (n. 12), p. 74.

${ }^{222}$ The Paris News Letter cit. (n. 4), p. 264. 
no había cometido traición, sino que por el contrario era uno de los pocos que permanecía fiel y leal a su conciencia, a Dios, y al derecho de la nación. Como señala Akroyd, "En este juicio, Moro estaba afirmando la primacía del propio derecho, en el sentido tradicional. Reafirmó las leyes de Dios y de la razón, tal como habían sido heredadas, y simplemente no creyó que el Parlamento inglés pudiese revocar las ordenanzas de hacía mil años. Es significativo que se le declarase culpable debido a aquella conversación con Rich en la cual él 'planteó un caso'. En cierto modo, se le condenó por actuar como un abogado y, durante el propio juicio, se le condenó a su vez por defender el derecho tradicional. Moro personificó el derecho toda su vida y murió por él"223.

\section{De Cómo un hombre PUEDE PERder La CABEZa Sin SUFrir DAÑo: "A MAN MAY LOSE HIS HEAD AND NOT BE HARMED"}

Terminado el juicio, el gobernador superior (“Constable”) de la Torre, sir William Kingston, junto con la guardia acompañaron al prisionero condenado de retorno a la Torre de Londres ${ }^{224}$. Cerca de la prisión lo esperaron sus hijos: John y Margaret se arrodillaron para recibir su bendición y, no contenta con ello, Margaret rompió la guardia para abrazar y besar a su padre. Durante los siguientes cinco días Moro se preparó para la muerte ayunando y rezando. Recibió la visita de su mujer, Lady Alice, y escribió un mensaje con un pedazo de carbón dirigido a Margaret ${ }^{225}$. En el intertanto, el rey concedió a Moro la gracia de que se conmutara la pena de ser descuartizado y destripado por la de decapitación ${ }^{226}$. El día 5 de julio Enrique VIII firmó la orden de ejecución ("warrant o writ of execution"), la que fue remitida ese mismo día al alguacil de la Torre ${ }^{227}$.

En la madrugada del día martes 6 de julio, entonces víspera de la fiesta del traslado de las reliquias de Tomás Becket, otro mártir que murió por defender la libertad de la Iglesia, el representante del Consejo del rey, sir Tomás Pope, se presentó en la celda de Moro y le informó que la ejecución tendría lugar ese mismo día a las 9 de la mañana ${ }^{228}$. Pope le transmitió la voluntad del rey de

${ }^{223}$ Akroyd, P., cit. (n. 24), p. 565.

${ }^{224}$ Cuenta Roper que Sir William era amigo de Moro, y que éste al verle tan afligido por el resultado del juicio le llamó a estar de buen ánimo ya que rezaría para que se juntaran en el cielo donde serían felices para siempre. Kingston le confidenció más tarde a Roper: "me daba vergüenza que al despedirme de vuestro padre hallé mi corazón tan frágil y el suyo tan fuerte que fue él el que tuvo que confortarme a mí cuando tenía que haber sido yo el que le confortara a él”: cfr. Roper, W., cit. (n. 12), p. 75.

${ }^{225}$ A ella le confió también diversos artículos, como su camiseta de pelo áspero (hair-shirt), que usaba como penitencia y de la que sólo Margaret sabía: cfr. GuY, J., cit. (n. 84), p. 263.

${ }^{226}$ Stapleton, T., cit. (n. 14), p. 195, sostiene que la conmutación de la pena no se debió a la clemencia del rey, sino a que esa forma de ejecución era la acostumbrada para aquellos hombres que eran ilustres ya sea por nacimiento o por oficio. El mismo relata que Moro, al saber que sería ejecutado por decapitación y no por la horrible pena de horca y descuartizamiento, habría dicho irónicamente: "Quiera Dios librar a mis amigos de tal clemencia real".

${ }^{227}$ GuY, J., cit. (n. 84), p. 263.

${ }^{228}$ Bellamy, J., cit. (n. 18), p. 188, piensa que, al igual que Fisher, Moro recibió la comunicación unas cuatro horas antes de la ejecución. 
que no empleara demasiadas palabras en ese momento, petición a la que Moro accedió inmediatamente no obstante haber pensado en pronunciar un discurso más extenso, si bien no en ofensa del rey ni de nadie. Pope terminó llorando y recibiendo el consuelo del prisionero.

Poco antes de las 9, Moro fue sacado de la celda y conducido a pie por unos 280 metros hasta Tower Hill, por entre la multitud que se había reunido para la ocasión. Saliendo de la jurisdicción de la Torre fue entregado a uno de los sheriffs de Londres, Humphrey Monmouth ${ }^{229}$. Ninguno de sus familiares fue autorizado a presenciar la ejecución ${ }^{230}$. Al subir al patíbulo, cuyos escalones eran inestables, uno de los funcionarios le ayudó a mantener el equilibrio, y en una prueba de que su humorismo le acompañaba incluso en esta hora, Moro le contestó que le ayudara a subir pero que para bajar podía dejar que lo hiciera solo ${ }^{231}$. Una vez en el tablado de la ejecución, Moro dirigió unas breves palabras a la multitud: junto con rogar a los presentes para que rezaran por él, declaró que sufría la muerte en y por la Santa Iglesia Católica ${ }^{232}$. Pidió también que rezaran para que Dios enviara buen consejo al rey, del cual él moría como su buen servidor, aunque de Dios primero ${ }^{233}$.

El hacha cayó sobre la cabeza y la barba de Moro. Su yerno William Roper resumió el momento en una frase hermosamente sencilla: "Así pasó sir Tomás Moro de este mundo a Dios" ${ }^{234}$. Prefirió como Sócrates padecer la injusticia, antes que cometerla ${ }^{235}$. El daño proviene de esto último y no de lo primero. Así lo había

\footnotetext{
${ }^{229}$ Monmouth era uno de los conquistados por las nuevas ideas religiosas, y por ello había sido enviado a la Torre por el mismo Moro. La paradoja del destino (o la providencia) es puesta de manifiesto por AKROYD, P., cit. (n. 24), p. 571.

${ }^{230}$ Solamente su hija adoptiva Margaret Giggs, casada con el preceptor de sus hijos John Clement, presenció la muerte de Moro: cfr. MarIUS, R., cit. (n. 22), p. 514.

${ }^{231}$ ROPER, W., cit. (n. 12), p. 79.

${ }^{232}$ ROPER, W., cit. (n. 12), p. 79.

${ }^{233} \mathrm{La}$ frase se ha hecho célebre en su formulación inglesa: "the King's good servant, but God's first": cfr. Chambers, R., cit. (n. 19), p. 349; incluso una de sus muchas biografías es titulada así: MonTI, J., cit. (n. 23). No obstante, los editores de A Thomas More Source Book sugieren que la traducción correcta de las palabras de Moro es la de "the King's good servant, and God's first" ("buen servidor del rey y de Dios primero"): Wegemer, G. y SMITH, S., cit. (n. 4), p. 357. Se basan en que el texto francés de la Paris News Letter reza: "qu'il mouroit son bon serviteur et de Dieu premierement". La Expositio, el Racconto italiano y la "Relación castellana" avalan la palabra "y" en vez de "pero": "contestans se morir fidelem ac bonum Regis ministrum, ac Dei in primis"; "protestando che moriva suo bueno servitore, \& principalmente del Signore Iddio"; "protestando que moría por su buen servidor y de Dios primeramente": cfr. "Relación castellana", cit. (n. 7), p. 400. En verdad, la diferencia no es demasiado importante porque el sentido de la frase es claro: Moro se declara servidor de las autoridades seculares pero obligado en primer lugar a las exigencias de Dios.

${ }^{234}$ ROPER, W., cit. (n. 12), p. 79.

${ }^{235}$ En la carta de Conrad Goclenius a Erasmo, fechada el 10 de agosto de 1535, probablemente desde Lovaina, en la que le anuncia la muerte de Moro, hace la comparación con Sócrates: "Tomás Moro fue ejecutado en Britania el 6 de julio, mostrándose él mismo no menos inquebrantable en su juicio y ejecución que Sócrates antes sus tristemente célebres perseguidores atenienses": citado por ReYNOLDS, E., cit. (n. 16), p. 9. Igualmente, HARPSFIELD, N., cit. (n. 13), p. 199, alude a la muerte de Sócrates y a la respuesta que habría dado a su mujer que le preguntaba si creía justo que un hombre bueno debiera morir, a lo que el filósofo
} 
comprendido y declarado Moro a su hija Margaret ya durante su prisión: "Bien sé que, aun si llegaran a hacer una ley para hacerme daño, esa ley nunca podría ser justa, pero espero que Dios me mantenga en aquella gracia, a saber, que, en lo que se refiere a mi deber a mi príncipe, ningún hombre me hará daño a no ser que se me haga una injusticia, y entonces, como ya te dije, esto es como un enigma: un caso en que un hombre puede perder su cabeza sin sufrir ningún daño ("this is like a riddle, a case in wich a man may lose his head and not be harmed') ${ }^{236}$.

\section{EpÍlogo}

El cuerpo de Moro fue sepultado por Margaret Roper y Margaret Clements en la Capilla de San Pedro ad Vincula ${ }^{237}$ en la Torre, para lo cual obtuvieron el permiso del lugarteniente de la prisión ${ }^{238}$. Para evitar que se suscitara un culto en la tumba de Moro, se arrojó sus despojos mortales a una fosa común. A ella pronto llegarían los restos de otra insigne decapitada: Ana Bolena (1536). Más adelante recibirían el cuerpo del acusador de Moro, Thomas Cromwell, también decapitado por traición a Enrique VIII, cinco años después de la muerte de Moro (1540). Actualmente, una inscripción recoge los nombres de las personas cuyos cuerpos descansan en este lugar ${ }^{239}$.

Pese a los resguardos de Moro, sus propiedades fueron confiscadas en favor del tesoro real. El trust que había constituido después de aprobarse la Ley de sucesión fue anulado por una Ley que aprobó el Parlamento a petición de Enrique ${ }^{240}$. En cambio, la transferencia hecha a su yerno William Roper sobre la propiedad de Butts Close no fue alcanzada por la ley de confiscación ${ }^{241}$.

habría contestado "es mejor para mí morir como un buen y auténtico hombre que vivir como un desgraciado malhechor”.

${ }^{236}$ Carta de Margaret Roper a Alice Alington, Agosto de 1534, en Moro, T., Cartas cit. (n. 11), p. 63.

${ }^{237}$ ReYnOlds, E., cit. (n. 16), p. 161, n. 2, destaca que la única otra iglesia que lleva este nombre se encuentra en Roma.

${ }^{238}$ Stapleton, T., cit. (n. 14), p. 213. Los detalles del entierro, incluso un suceso milagroso por el cual las dos Margaret obtuvieron la tela con la que sepultaron a Moro, fueron contados a Stapleton por la sirvienta de Margaret Roper, Dorothy Harris, que aún vivía exiliada en Douai. Según testimonia Stapleton, la misma Margaret Clements, también exiliada de Inglaterra, le mostró la camisa con la cual Moro fue decapitado, que conservaba aún las manchas de su sangre, y le regaló un trozo: STAPLETON, T., cit. (n. 14), p. 214.

${ }^{239}$ VÁsqueZ de Prada, A., cit. (n. 20), pp. 371-372.

${ }^{240}$ La ley (27 Hen.VIII c. 58) es citada por Guy, J., cit. (n. 84), p. 325. No obstante, dos pequeñas propiedades se libraron de la confiscación legal. Una de ellas fue una casa solariega de Sutton cerca de Chiswick. La otra era una finca, arrendada al Monasterio de Westminster, y situada en las orillas del río en Battersea. William Roper, entendiendo que pertenecía a la dote de Margaret, trató de disputarla a la viuda de Moro, Alice, y el asunto llegó a los tribunales, los que dieron la razón a la viuda. Esta obtuvo permiso para vivir en una pequeña propiedad, que había pertenecido a la estancia de Chelsea. Esta última fue concedida por el rey a Sir William Paulet: cfr. GuY, J., cit. (n. 84), p. 325. También fue otorgada a Lady Alice una pensión de 20 libras al año, con la cual podía vivir, aunque estrechamente: cfr. STAPLETON, T., cit. (n. 14), pp. 214-215.

${ }^{241}$ Así lo cuenta su propio beneficiario: Roper, W., cit. (n. 12), p. 62: "Y de esta manera, 
La cabeza de Moro estuvo durante un mes en la pica en la que fue colocada después de su ejecución en la entrada del puente de Londres. Para evitar que terminara arrojada al río Támesis, como era lo dispuesto, su hija Margaret sobornó al funcionario encargado de remover las cabezas de los ejecutados y se llevó la cabeza de su padre a su casa como preciada reliquia ${ }^{242}$. Cromwell trató de evitar que quedaran estos restos de Moro, y obtuvo que Margaret fuera citada al Consejo del rey acusada de estar guardando la cabeza de su padre como reliquia sagrada y retener la posesión de sus libros y escritos. La acusada se defendió diciendo que sólo había salvado la cabeza de ser comida por los peces del Támesis y con la intención de darle sepultura, y que mantenía libros ya publicados, escritos y cartas personales, que rogaba se le dejaran para su propia consolación. El Consejo no se atrevió a condenarla y la dejó en libertad ${ }^{243}$. Margaret siguió empeñada, secretamente, en la recolección y edición de las obras de su padre para preservar su memoria, para lo cual recontrató a John Harris, el antiguo secretario de Moro ${ }^{244}$. Moriría en 1544 sin ver su propósito cumplido: sólo después de 20 años, durante el reinado de la católica María Tudor, salió finalmente a la luz, en abril de 1557, la primera edición de las obras de Moro: The Works of sir Thomas More, Knight, Sometime lord Chancellor of England, Written by him in the English Tongue, con un total de 1.458 páginas.

Después de la muerte de Margaret Roper, hay dudas sobre la suerte de la cabeza de Moro; mientras algunos testimonios cuentan que Margaret fue enterrada con la cabeza de su padre entre sus manos ${ }^{245}$, otros señalan que quedó en custodia de otros parientes. Al parecer la cabeza vino finalmente a ser enterrada en un nicho de la cripta de la familia Roper en la Iglesia de St. Dunstan, en Canterbury. En 1932 se puso una inscripción en el piso de la ahora Capilla de San Nicolás, con una inscripción que señala que bajo ella se encuentra la cripta de la familia Roper donde se encuentra enterrada la cabeza de sir Tomás Moro, de ilustre memoria, en su momento lord canciller de Inglaterra, decapitado en Tower Hill el 6 de julio de 1535. Y termina con una exhortación que seguramente el mismo Moro encontraría una acertada síntesis de una de las aspiraciones, junto con el imperio del Derecho, por las que ofreció su vida: "Ecclesia Anglicana Libera Sit"246.

[Recibido el 3 de mayo y aprobado el 2 de julio de 2010].

como el estatuto sólo había anulado el primer traspaso, no dando al rey sino lo que allí se traspasaba, el segundo traspaso - en donde se concedía a mi mujer y a mí-como estaba fechado dos días después, no estaba dentro del alcance del estatuto, y de este modo quedó nuestra parte reservada con claridad para nosotros".

${ }^{242}$ StApleton, T., cit. (n. 14), p. 213, señala que Margaret custodió con reverencia la cabeza de Moro, preservándola con especies.

${ }^{243}$ Stapleton, T., cit. (n. 14), p. 215, señala que fue gracias a los buenos oficios de amigos que ella fue liberada. GuY, J., cit. (n. 84), p. 325, sostiene que los interrogatorios fueron dos: uno sobre la cabeza y otro sobre los escritos y libros de Moro.

${ }^{244}$ GuY, J., cit. (n. 84), p. 266.

${ }^{245} \mathrm{El}$ dato proviene del relato del funeral proporcionado por Margaret Hillary: cfr. GuY, J., cit. (n. 84), p. 270.

${ }^{246}$ Cfr. Reynolds, E., cit. (n. 16), pp. 164-165. 


\section{BiBLIOGRAFÍA}

Akroyd, Peter, The Life of Thomas More (Chatto \& Windus, London, 1998).

Álcaraz Varó, Enrique - Hughes, Brian, Diccionario de términos jurídicos/ A Dictionary of Legal Terms (Inglés-Español/Spanish-English) (10ª edic., Madrid, 2007).

Bellamy, John, Tudor Law of Treason. An introduction (Toronto y Buffalo, 1979).

Berglar, Peter, La hora de Tomás Moro. Sólo frente al poder (trad. cast., Madrid, 1993).

Bernard, G. W., The King's Reformation. Henry VIII and the remaking of the English Church (New Haven y London, 2005).

Bolt, Robert, A Man for All Seasons. A Play of Sir Thomas More (London, 1995).

Chambers, R. W., Thomas More (5a edición, U.S.A., 1973).

Derret, J. Duncan M., More'Silence and his Trial, en Moreana, 22 (1985) , 87-88.

Derret, J. Duncan M., Sir Thomas More and the Nun of Kent, en Moreana, 15-16 (1967).

Derret, J. Duncan M., The Trial of Sir Thomas More, en Sylvester, R. S. Marc'Hadour, G. P. (editores), Essential Articles for the Study of Thomas More (Hamden, Connecticut, 1977).

Derret, J. Duncan M., Thomas More and the Legislation of the Corporation of London, en Sylvester, R. S. - Marc'hadour, G. P. (editores), Essential Articles for the study of Thomas More (Hamden, Connecticut, 1977).

Derret, J., The 'New' Document on Tomás More's Trial, en Moreana, 3 (1964).

Discours sur le procez et execution de Thomas Morus, chancellier d'Angleterre, en Harpsfield, Nicholas, The Life and Death of St. Thomas Moore, Knight, Sometymes Lord High Chancellor of England (London, 1932, reimp. 1963).

Elton, G. R., Sir Thomas More and the Opposition to Henry VIII, en Sylvester, R. S. - Marc'HAdour, G. P. (editores), Essential Articles for the Study of Thomas More (Hamden, Connecticut, 1977).

ENRIQUE VIII, Assertio septem Sacramentorum.

Expositio fidelis de morte D. Thomae Mori et quorundam aliorum insignium virorum in Anglia.

GuY, J. A., The Public Career, of Sir Thomas More (New Haven y London, 1980).

GuY, John, A Daughter's Love. Tomás More \& his Dearest Meg (Boston/New York, 2009).

GuY, John, Thomas More (London, 2000).

GuY, John, Thomas More and Cristopher St. German: The Battle of the Books, en Moreana, 21 (1984) 83-84.

Harpsfield, Nicholas, The Life and Death of St. Thomas Moore, Knight, sometymes Lord High Chancellor of England (London, 1932, reimp. 1963).

Hutchinson, Robert, Thomas Cromwell. The Rise and Fall of Henry VIII's Most Notorius Minister (New York, 2009).

Lambard, William, A Perambulation of Kent: Conteining the Description, Hystoric and Customes of that Shyre (1576).

LuTERo, Martin, De captivitate Babilónica ecclesiae praeludium.

MacCulloch, Diarmaid, Thomas Cranmer (New Haven -London, 1996).

Marc'Hadour, Germain, L'univers de Thomas More. Cronologie critique de More, Erasme e leur époque (1477-1536) (Paris, 1963). 
Marius, Richard, Thomas More (New York, 1985).

Mattingly, Garret, Catalina de Aragón (trad. castellana, 2a edic., Madrid, 1998).

MonTI, James, The King's Good Servant, But God's First. The Life and Writtings of St. Thomas More (San Francisco, 1997).

Moro, Cresacre, The Life of Sir Thomas More (London, 1828, reimp. 2010).

Moro, Tomás, La agonía de Cristo (trad. castellana, $3^{a}$ edic., Madrid, 1989).

Moro, Tomás, Piensa la muerte (trad. castellana, Madrid, 2006).

Moro, Tomás, St. Thomas More: Selected Letters (Rogers, Elizabeth F. edit., 2a edic., New Haven y London, 1967).

Moro, Tomás, The Answer to The First Part of the Poisoned Book Wich a Nameless Heretic Hath Named the Supper of the Lord.

Moro, Tomás, The Correspondence of Sir Thomas More (Rogers, Elizabeth F., edit., Princeton, 1947).

Moro, Tomás, The Four Last Things, en El mismo, The Four Last Things. The Supplication of Souls. A Dialogue on Conscience (New York, 2002).

Moro, Tomás, Un hombre para todas las horas. La correspondencia de Tomás Moro (1499-1534) (Silva, Álvaro de, Madrid, 1998).

Moro, Tomás, Un hombre solo. Cartas desde la Torre (Silva, Álvaro de, edit., Madrid, 1990);

Moro, Tomás, Utopia (trad. castellana, 5ª reimp, Madrid, 2004).

Neame, Alan, The Holy Maid of Kent: The Life of Elizabeth Barton: 1506-1534 (London, 1971).

Ordo condemnationis Thomae Mori, Cancellarii Primarii Aliquando Regni Angliae, quia in incestas nuptias Henrici Octavi assentiri, eumque caput summum Ecclesie Anglicanae fateri noluerit: compendio latine redditus: anno illoquo ille perierat

Pole, Reginald, Pole's Defense of the Unity of the Church (1539, trad. inglesa, Westminster MD, 1965).

Pro ecclesiasticae unitates defensione (Roma, 1539).

ReYnolds, E. E., An Unnoticed Document, en Moreana, 1 (1963).

ReYnolds, E. E., One of Thomas More's Judge, en Moreana, 54 (1977).

Reynolds, E. E., The Trial of St. Thomas More (Great Britain, 1964).

Roper, William, La vida de Sir Tomás Moro (trad. castellana, 2a edición, Navarra, 2001).

Ruscelli, G., Lettere di principe, le quali o si scrivono da principi, o a principi, o ragionan di principi (Venezia, 1562),

Sardaro, Anna, La correspondencia de Tomás Moro. Análisis y comentario críticohistórico (Pamplona, 2007).

Schwarz, Arthur L. (editor), Vivat Rex! An Exhibition Commemorating the 500th Anniversary of the Accesion of Henry VIII (New York, 2009).

StAPleton, Thomas, The Life and Ilustrious Martyrdom of Sir Thomas More (Part. III of 'Tres Thomae', printed as Douai, 1588) (trad. Philip E. Hallett, Chicago, 1928, reimp. 2009).

TÁcito, Cornelio, Anales (trad. castellana, Madrid, 1979).

The Paris News Letter, en Harpsfield, Nicholas, The Life and Death of St. Thomas Moore.

VÁsquez de PRADA, Andrés, Sir Tomás Moro, Lord canciller de Inglaterra (6a edición, Madrid, 1999). 
Vásquez de Prada, Andrés, Sir Tomás Moro, Lord canciller de Inglaterra (Madrid, 1966).

Wabuda, Susan, The Reformation of the English Church under Henry VIII, en Schwarz, Arthur L. (editor), Vivat Rex! An Exhibition Commemorating the 500th Anniversary of the Accesion of Henry VIII (New York, 2009).

WaTt, Daniel, The Prophet at Home: Elizabeth Barton and the Influence of Bridget of Sweden and Catherine of Sienne, en VOADEN, Rosalynn (editora), Prophets Abroad. The Reception of Continental Holy Woman en Late-Medieval England (Cambridge, reimp. 1999).

Wegemer, Gerard B. - Smith, Stephen W. (editores), A Thomas More Source Book (Washington, 2004). 